\title{
THE
}

\section{ORIGIN AND EARLY HISTORY}

\author{
OF THE
}

\section{OFFICE OF NOTARY}

BY

JAMES COWIE BROWN

M.A. (Glasg.), LL.B. (Edin.), Ph.D. (Edin.),

Officier d'Académie

\section{WITH A FOREWORD}

BY

The Right Honourable THE VISCOUNT DUNEDIN

P.C., G.C.V.O.

Formerly a Lord President of the Court of Session and lately a Lord of Appeal-in-Ordinary.

\section{EDINBURGH}

W. GREEN \& SON, LIMITED

LAW PUBLISHERS 
THE ORIGIN AND EARLY HISTORY OF THE OFFICE OF NOTARY 
TO MY WIFE 


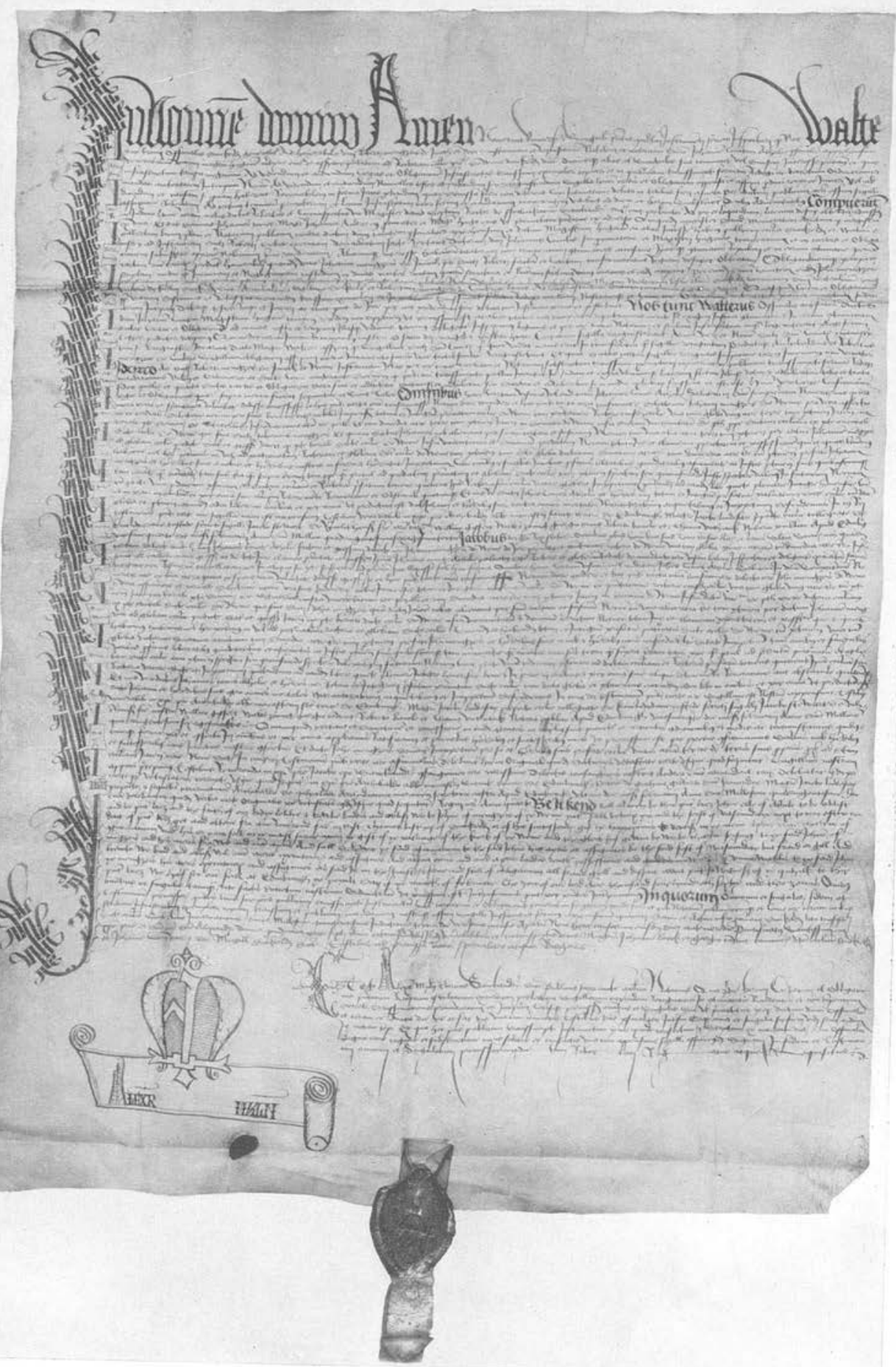

Notarial Instrument executed in 1500 By Alexr. Myln, subsequently Lord President of the Court of Session. 


\title{
THE \\ ORIGIN AND EARLY HISTORY \\ OF THE
}

\section{OFFICE OF NOTARY}

BY

\begin{abstract}
JAMES COWIE BROWN
M.A. (GLASG.), LL.B. (EDIN.), Ph.D.(BDIN.),

OFEIOIER D'AOADÉMTE
\end{abstract}

\section{WITH A FOREWORD}

BY

The Right Honourable THE VISCOUNT DUNEDIN P.C., G.c.V.o.

Formerly Lord Justice-General and Lord President of the Court of Session in Scotland and lately a Lord of Appeal-in-Ordinary

\author{
EDINBURGH \\ W. GREEN \& SON, LIMITED \\ LAW PUBLISHERS \\ 1936
}


Non erit alia lex Romæ, alia Athenis, alia nunc, alia posthac, sed et apud omnes gentes, et omni tempore una lex et sempiterna et immortalis, continebit.

Crorro. De Reipublica.

"Besides, I know thou art

A public Notary, and such stand in law

For a dozen witnesses."

Massinger. A New Way to Pay Old Debts. 


\section{PREFACE}

THIs Thesis was originally accepted for the degree of Doctor of Philosophy (in Law) of the University of Edinburgh. It subsequently appeared in The Juridical Review and is now issued as a separate publication in response to requests from librarians and others.

So far as is known the subject has never before been dealt with on the present lines, and recourse has had to be made to original sources, largely to the works of early German and French jurists and, as the main and finally authoritative background, to the Novels, Code, Digest and Institutes of Justinian. Research has also been necessitated in regard to the early Byzantine Empire, Sicily, Malta and Egypt, indeed to all the mercantile area of the Mediterranean. The subject has been treated down to the early seventh century and, while the author hopes to continue the study down to the present day with special reference to the Reception of Roman Law in Scotland in this particular sphere, the present study may provide a helpful basis for another to continue the work in the event of that hope not materialising.

I should like to record my thanks to Professor R. K. Hannay, LL.D., for his kind interest and help, to Dr. C. A. Malcolm (S.S.C. Library), and to Dr James Corson (University Library) for valuable assistance. To the Rev. Thomas Miller I am due a deep debt of gratitude for drawing my attention to this interesting field of research and for many useful suggestions.

Finally, to Viscount Dunedin I beg to tender my grateful thanks for his interest and for the Foreword he has been so good as to write.

J. C. B.

EDINBURGH, March 1936. 


\section{FOREWORD}

I HAVE pleasure in acceding to the request to write a foreword to this little essay. I do so, not to say that it is interesting-that the reader can find out for himself-but because I should like to impress on the practising lawyer how much he has to gain by the publication of such studies as this. I was a practising lawyer myself, and I know how impossible it is for such really to devote attention to historical research. It was different in older days. I have no hesitation in admitting that the Judges of the first three-quarters of the nineteenth century were in the practice of historical investigation more learned in the law than the generation that succeeded them, to which I and others belong. They had indeed more time, but they had not so much material. So that historical investigation has, so to speak, passed into other hands, and it is a great assistance to the practising lawyer to find given him in a clear and succinct form what it would have taken him much study to find out for himself such as would not be consonant with the pressing claims of practice. We are all hoping that the newly founded Stair Society may pave the way for the real Scottish Law Historian. DUNEDIN.

\section{LONDON,}

June 1935. 


\section{CONTENTS}

Notarial Instrument (1500) by Alexr. Myla Frontispiece CBAP.

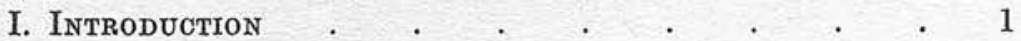

II. The "Scriba" and Similar Functionaries . . . 8

(1) The Scriba.

(2) The Notarius.

(3) The Amanuensis and the Cancellarius.

(4) The Exceptor.

(5) The Pragmaticus.

(6) The Tabularius or Tabellarius.

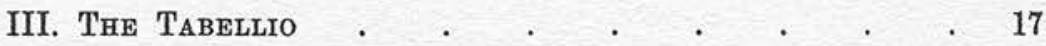

IV. Qualifications and Duties of the Tabellio • • 22

(A) Qualifications.

(B) Duties.

(C) Disciplinary Measures . . . . . . . . . $\quad 26$

V. The Laws of Justinian Regarding Tabellions . . 27

VI. The Drawing-up of Instruments _ . . . . 34
(A) The Scheda.
(B) The Contents.
(C) The Writer.
(D) The Protocol.
(E) The Language.
(F) The Date.
(G) The Seal and Subscriptions.
(H) The Completio and Absolutio.
(I) Errors and Corrections.

VII. EVIDENCE • • . 40

(A) General Rules as to Witnesses.

(B) Witnesses, Comparison of Handwriting, and Oaths.

VIII. Conclusions. 
PAGBS ApPENDices . . . . . . . . . . $\mathrm{i}-\mathrm{xlix}$

(A) Novel XLIV. of Justinian (with Gothofred's notes) . i Commentary thereon by Cujacius . . . . ix Novel LXXII. of Justinian (with Gothofred's notes) xiii Commentary thereon by Cujacius . . . . xxvii (All with Latin and English Calendar.)

(B) Code of Theodosius, Lib. VI. Tit. X. (De Primicerio et Notariis) . . . . . . . . $\mathbf{x x x}$

(C) Selection of Instruments (Spangenberg) . . . . xli

(1) Testamentum sollemne Mannanis . . . . xli

(2) Fragmentum Instrumenti donat. Gaudioso . xlv

(3) Instrumentum donat. Stephani Græci . . . xlvi

(4) Instrumentum donat. Sisiveræ . . . . xlvii

(D) Extract from Ars Notariatus . . . . . . xlviii

(E) Extracts from Schöell's Latin Version of Novels

XLIV. and LXXIII. . . . . . . . . 1 


\title{
THE ORIGIN AND EARLY HISTORY OF THE OFFICE OF NOTARY
}

\author{
CHAPTER I \\ INTRODUCTION
}

As old philosopher has said that "to begin at the beginning is, next to ending at the end, the whole art of writing." On this theory we should logically begin with an account of Roman and Byzantine law in the centuries prior to A.D. 600. But sufficient has been adequately expounded elsewhere to excuse an incursion into the general principles of Roman law, and also into an account of the legal sources in these early centuries. This thesis, therefore, presumes a knowledge of the legal and social structure prevailing in the Roman Empire during the six centuries after the birth of Christ, and no attempt has been made to evaluate the works of Theodosius or his successors with the exception of Justinian in so far as his Novels (XLIV. and LXXIII.) dealing with the Notary are specially dealt with hereafter, and in regard to appropriate and relevant passages in the Code, Digest, and Institutes, which are utilised with the necessary citation where they have special application. That general information may easily be found in the numerous text-books on Roman law. It is necessary, however, to point out that a proper understanding of the following study is only to be derived on the basis that the reader is familiar with, at least, the main characteristics of Roman law in the period referred to.

The problem of tracing the Notary from the origin of his office through the ages is not an easy one. It has involved investigation into many byways apart from the works of Justinian, Gaius, and of the numerous Glossators 
and Commentators. These sources are referred to as and when they have been utilised.

Some criticism may be made as to why the office of the Notary should require such recourse to the early days of his existence. The reply is that of all historians, that an adequate understanding of any subject requires an investigation into the fons et origo: in the words of our old philosopher, "to begin at the beginning." There is nothing new under the sun, and certainly to this very day we can trace certain functions of the Notary back nearly two thousand years. It is surprising, and possibly astonishing to many, to know that Roman legal thought so many centuries ago devised a system which has survived the long ages of legal change and turmoil which have intervened between the tabellio and his modern successor.

But a more cogent reason exists than an investigation simply into the history and development of the office of the Notary. The reception of Roman law in Scotland has given rise to much controversy. ${ }^{1}$ While it is certain that a great influence on Scots law arose from the fact that in the Middle Ages Scots lawyers regularly studied abroad at Paris, Orleans, and even Bologna and Pavia, and in a later age at the colleges of Utrecht, Leyden and Heidelberg, and unquestionably must have brought back with them principles of Roman law which were incorporated into the Scots legal system, yet great difficulty attaches to tracing the arrival and adoption of these or the proceeds of any other absorptions of Roman influence earlier than the thirteenth century and, indeed, not with any great certainty for centuries thereafter. ${ }^{2}$ It is thought that an investigation into the origin of the Notary-with regard to a subsequent study of the reception in Scotland of Roman

1 Vide Dove Wilson, "Reception of Roman Law in Scotland," Juridical Review, ix. 361 .

2 Vide Lord Macmillan's Rede Lecture to the University of Cambridge, recently published under the title of "Two Ways of Thinking" (1934), where the sojourn of Viscount Stair in Holland is cited as influencing the Institutions of that great jurist who is generally recognised as the father of Scottish Jurisprudence. 
law, which is a natural sequel to the present study-may throw new light on this dark problem, especially as it is hoped ultimately to examine the notarial system in general and notarial deeds in particular in both fields and possibly therefrom fix with a greater attempt at certainty than previously has been attained when and how Roman law originated or influenced a great part of our Scots legal system. ${ }^{1}$

The need for such information may seem purely historical, but it has been lately evidenced in remarkable fashion that Roman law is by no means unimportant even in the twentieth century. A reference to Professor Mackintosh's Tagore Lectures of 1933 will carry ample conviction on this point. ${ }^{2}$ The question of the vicennial prescription of crime, based on Roman law, has been before the High Court of Justiciary in the present year. ${ }^{3}$

The importance of the office of Notary throughout the ages can hardly be over-estimated. From the very earliest times, ${ }^{4}$ scribes, the forerunners of the modern notaries, have played an important part. In the early days of the Roman Empire the notary began to take an increasing share in every sphere of life, in private, in public, and in International law, and in particular in the realm of mercantile law.

Since the art of writing in the early days of the Empire was confined to a very few, during the first centuries A.D. agreements were purely verbal. Contracts were generally made orally in the presence of witnesses: the parties simply met in the presence of some people known to them,

1 Vide Dove Wilson, "Reception of Roman Law in Scotland," Juridical Review, ix. 361.

2 Tagore Lectures, 1933, by Professor James Mackintosh, K.C., LL.D., published under the title of Roman Law in Modern Practice (Edinburgh, 1934).

${ }^{3}$ Sugden v. H.M. Advocate, 1934, S.L.T. 465.

${ }^{4}$ An early MS. on the Office of Notary in the National Library of Scotland commences: "In process of time as honesty and ingenuity decayed and where parties could not rely on one another's words nor bare entering them into possession, writs became necessary in the transmission of the property of lands. One example is where Jeremiah says I bought the field of Hamaliel my Uncle's Son, that was in Anahoth and weighed him the money, even seventeen shekels, and subscribed the evidence and sealed it and took witnesses." 
if possible, and, after discussion, reached an agreement, thereafter calling upon the witnesses present, who might be merely passers-by, to remember what they had seen and heard, and if necessary to witness to the truth of the transaction if called upon to do so. Naturally the increase in the number of persons versed in the art of writing and the difficulty of securing witnesses at a date that might be very distant, rendered the necessity of some definite record imperative. That, in turn, led to a recourse to people who could reduce agreements to writing. Hence the rise of the scribce, notarii, tabularii, and tabelliones.

With the growth of freedom of intercourse and with the development of commerce and organised civil life, instruments of contract, dispositions of property in succession and otherwise, and the numerous other written agreements necessary between individuals in a civilised State where writing was becoming more common, were ever more and more required; Cujacius refers to ingens numerus contrahentium.

In the sphere of public law it was essential, and increasingly so, to have decreets and Court proceedings carefully noted, approved by the appropriate authority, and registered, while the development of the "law merchant" had possibly a greater influence than anything on the importance of the notarial office, and there is no doubt that in this sphere the itinerant scribe also played a large part. ${ }^{1}$ In effect practically any documents of importance from the days of the Early Roman Empire onwards-to this very day in some countries-were drawn by notaries. ${ }^{2}$

In more modern times many of the functions of the notaries have been shed consequent on the march of civilisa-

1 Savigny: Geschichte des Römischen Rechts, i. 457. This explains why law doctrines are often met with in unexpected places and times. Mur. ant. Ital. T., i. 666 D; Marini papiri, N. 315.

2 "Sa fonction avait un caractère si universel que rien n'y échappait, ni la politique, ni l'art, ni le commerce, ni l'industrie, ni la vie publique, ni le foyer." -Blanchard: Documents inédits sur le commerce de Marseilles du moyen áge, i. $x x x v i$. 
tion and with the growth of statutory or codified law, but their position is still important in varying degrees. Undoubtedly from the early Empire till the Middle Ages they held an office of importance and power. Their position was consolidated with the renaissance of Roman law when the law schools of Bologna and other famous schools were instituted, and they owed not a little to the Glossators and Commentators who certainly took immense pains to investigate and consolidate the early laws of Justinian and Theodosius with the subsequent rules which had grown up from time to time. Bartolus, one of the greatest commentators, devotes over a hundred references to this subject alone in the Index to his Commentaries on Justinian's works, and if to that is added his Commentaries on witnesses and on the construction of instruments in general, the Index references total many hundreds.

It is noteworthy that almost all the leading Glossators and Commentators were notaries, and that several have contributed largely to the literature of the subject. ${ }^{1}$

It is certain that the office of notary may be stated to be derived from a system in use in the days of the Early Roman Empire. The term "notarius," says Craig, 2 "nomen antiquum est." "The value of their services," according to Craig, "was first recognised in Courts of Law and the name notarius meant one who wrote from dictation in an abbreviated hand."

Modestine ${ }^{3}$ says that those "who take down the pronouncements of the Governors are certainly engaged on State service." Suetonius tells us that "the Emperor Titus was a skilled shorthand writer." Pliny, in his Epistles, states that "he arranged for a notary to come on an appointed day and that he dictated to him what he had

1 Notably Bartolus, also Rainerius de Perusio, Petrus de Vinea, Petrus de Ungola, Petrus Boaterius, and Salathiel. Petrus de Vinea, in fact, was made Protonotar by K. Friedrich II. These flourished, of course, in the thirteenth century. Bartolus, vide p. 47, f.n. 1, infra.

${ }^{2}$ Jus. Feud.II. vii.7. $\quad$ s $l .33$, §1.ff. ex quibus causis major integr. restit., D.4.6. 
composed," and we find mention in Martial of "Notarii" and "Calculatores." The tabellio is dealt with in detail later.

During the early centuries of the Christian era agreements were purely verbal. Contracts were made orally, and, as we have said, if possible in the presence of witnesses. The parties met in the most frequented places, such as the market-place. There they discussed the matter in hand, came to an agreement, and called on those in the vicinity to keep in mind what they had seen or heard, so that they might, if called upon, testify to what had been done. The difficulties attached to the proof of such agreements were obvious and increased as civilisation developed, with the natural result that openings for dishonesty presented themselves. A natural result was a demand for something in the nature of agreed forms, and something more reliable than the mere remembrance of casual witnesses. The art of writing was now becoming more common, ${ }^{1}$ and the obvious sequence was that parties wishing to make a contract should put their intentions into writing and authenticate them by affixing their seals to the document which embodied their agreement. By seals it must be remembered that these did not represent signatures. The seal was often the simple affixation of an individual signet or other personal sign. In the early days of the Empire when the art of writing was confined to few, it followed, therefore, as a matter of course that those who could write should lend their aid to those who could not. Some persons, undoubtedly, did so lend their services gratuitously and in the ordinary course of obligement or friendship. Others, finding here an honourable and lucrative occupation, set up in business as public writers or scribes, and

${ }_{1}$ Early Roman law used writing very little, but it is clear that, under Greek influence, legal documents had become common before the end of the Republic. Wills were almost always in writing; stipulations were already classed by Cicero among res quce scripto aguntur. Vide Jolowicz: Historical Introduction to Roman Law, p. 424 et seq. Vide also Maine, Ancient Law, p. 168: "The Comitia Calata, assembled for the validation of Testaments. ... Wills exhibited were not enrolled but simply recited to the members who were supposed to take note of their tenor and to commit them to memory." 
by the time the art of writing had grown more common were fairly entrenched in what in effect had grown to be a distinct profession, since the importance of the work carried out by these writers naturally led to the idea of laying down definite rules for them. Of such a type must have been the scribes of the Hebrews, the treasurers at Athens, and other similar officials. The deeds written by these scribes were then regarded only as private writings. To make them authentic the parties had to produce them in the presence of a certain number of witnesses before a magistrate, who had authority to affix a public seal.

Confusion is obvious in the writings of the Commentators in regard to the exact significance of notarius, tabellio, and other similar functionaries, and it has been thought advisable to give a description of these various persons, separatim, and thereafter to trace the early history and office of the tabellio as the prototype of the modern notary as we understand that official.

It may not be out of place here to suggest that the 73rd Novel of Justinian (which is treated specially hereafter as dealing specifically with the solemnities attending upon the making of instruments by tabellions) must have found its way to Scotland. ${ }^{1}$ The Novel is cited in Ivo's Decretum. Also the adoption of a decree that, inter alia, judges should employ by preference Notaries as Clerks of Court and its promulgation by the Canon of Innocent III. in 1215 (No. 38 of the Lateran Council of 1215) established the system in Europe as a whole as well as in Scotland. This Canon was almost certainly brought to Scotland by William de Malvoisin, Bishop of St. Andrews, who was present when the Canon was passed. Ivo's Decretum was not only received in Scotland with the approval of David I. but was also taught in the Papal schools before the time of Gratian.2 Sir Thomas Craig makes special reference to the 73rd Novel. ${ }^{1}$

1 Jus Freud. II. vii. 7.

2 Vide Miller, "Scotland in the History of Roman Law," Juridical Review, xxxvii. 162. 


\section{CHAPTER II}

THE " SCRIBA" AND SIMILAR FUNCTIONARIES

\section{(1) The Scriba.}

Originally copiers or transcribers of documents, the scribce rose in importance with the spread of writing and written instruments. In the classic period, and in the times of the early jurists, scriba was the general term for a Clerk of Court, ${ }^{1}$ though often used for anyone professing the act of writing. They differ from the exceptores. ${ }^{2}$ According to Brooke ${ }^{3}$ (and he is borne out by the early commentators) their occupations varied, some being permanent Court officials-attached mainly to the Chancellery-who recorded proceedings and registered judgments, others being engaged in private practice, chiefly concerned with drafting deeds of various kinds. According to an anonymous work, Ars Notariatus, ${ }^{4}$ the scribce were appointed "to dress and form the Acts and judicial Proceedings of the higher Judges, and were called scriptores notarii libellenses; whose office now at this time is, to make up the Acts of Court, to write the Testimonies of Witnesses, Allegations of Parties, the Orders, Sentences and Decrees of the Judges, and whom we call Clerks of Court." The scribce were bond slaves, until Arcadius and Honorius 5 forbade, under severe penalties, any slave to take on himself the office of scriba. ${ }^{6}$ Scriba was also used as a wide general expression for anyone who was able to

1 Cod. Theod. l. 18, § 17. D. de Muner. l. 4.

${ }^{2}$ See p. 12, infra.

- Notary, 8th ed., p. 1.

4 Published in Edinburgh in 1740.

5 A.D. 401.

- Cod. de Tabul. l. 3. 
write. ${ }^{1}$ Scriba has also been used to signify the same as librarius. ${ }^{1}$

(2) The Notarius.

Originally a notarius was a writer, probably associated with the scriba, who took down material for deeds in the form of notce, ${ }^{2}$ using what in effect was a system of shorthand. ${ }^{3}$ Notarius dicimus eos qui scribunt notis. ${ }^{4}$ Up to the fourth century, the notarii, who were slaves or freedmen, wrote their notce to the dictation of the parties who requisitioned their services. ${ }^{5}$ In the early days of the Empire, the notarii wrote down their notes and gave them to the tabelliones, who alone had the right to draw up deeds from these notes which were regarded as a species of draft. The new drawing-up, completio contractus, constituted a regular instrument. The notarii were not only writers for private persons but also officiated in compiling notes for magistrates and for jurists. ${ }^{6}$

These notarii, as we have said, were originally slaves or freedmen. In addition to their writing duties they appear to have taken rank with the other slaves of their masters in ordinary domestic occupations. The Roman citizens considered such functions as the notarii performed to be beneath their dignity.?

1 Reference may also be made to Spangenberg, Juris Romance Tabulce Negotiorum Solemnium, cap. 2: Scribce vel librarii, etr

2 Hence the term "notarius." Vide f.n. 6, infra.

3 The notarii have been called "early stenographers" (Dictionnaire historique des Inst. mours et cout. de la France: V. notes livonierres). Qui notas Tachygraphicas callerent notarii vocabantur: Spangenberg, loc. cit., cap. 2.

- Cujacius, Observ. xii. $40 . \quad$ 'Notarii sunt servi qui ad scribendum operas locant: Cujacius, Observ. on C. viii. 11, 17.

- D. iv. 6, 33, § 1: Eos qui notis scribunt acta Prøsidum. Gothofred's note in regard to notis reads: "Notis olim excipere solebant acta judicum, cum aliter non possent loquentis celeritatem manu adsequi: quod Ammianus ostendit apertissime lib. 14. Idem mos in Senatus consultis et Edictis scribendis, uti colligitur ex Valerio Probo in notis. Unde Manilius: 'et his scriptor erit felix, cui littera verbum est quique notis linguam superet, cursuque loquentis excipiat longas nova per compendia voces': et mox: 'Hic etiam legum Tabulas et condita jura noverit, atque notis levibus pendentia jura.' Hinc notarii."

7 Montesquieu, Grandeur et décadence des Romains, c. x. The value of a notarius as a slave was stated to be 50 solidi, c. vi. 44,3 . 
In the latter end of the fourth century and during the fifth century, the term notarius became principally applicable to officials of the Imperial Chancery. They were divided into different grades of office, according to their rank and the duties entrusted to them. The Chief Secretary of the State, the head of the notarii, was the primicerius notariorum. ${ }^{1}$ A full account of the College of Notaries is given in the Code of Theodosius, Lib. vi. Tit. x.: De Primicerio et Notariis. ${ }^{2}$ In a lower grade we find the tribunius and notarius who were responsible, inter alia, for compiling the list of public officials and their salaries. ${ }^{3}$ The term notarius did not, however, lose entirely its old significance even at the end of the fifth century.

It should be noted that the terms actuarii and notarii had, in the early days of the Empire, practically the same meaning, and at times we even find the terms cursores 4 or logographi used in a similar sense.

Reference should also be made to notarii who, in the early centuries of the Church, were Ecclesiastical officers, "their office being to gather and preserve the Acts of the martyrs. They were seven in number, and every one had his station in the City of Rome. St. Clement, the fourth Pope, was the first who established these Notaries, and assigned them their different stations in Rome, for to write the Acts of the martyrs who should suffer there: as we learn from the Liber Pontificalis of the third century, St. Fabien, a later Pope, considering that the Scriptures in shorthand ${ }^{5}$ were very obscure, added seven sub-deacons to these notaries, to the end that they should take care to write out, at length without abbreviations, that which the notaries had written in shorthand. These

1 Vide infra, p. 22.

2 Vide Chapter IV., infra, and Appendix B.

3 Savigny, Geschichte des Römischen Rechts, i. 51.

- Vide De Cursoribus, ad Hist. Ang. Scriptt, 227.

5 Here again we see the early significance of the notarius as a writer in shorthand. 
notaries had likewise the care of the patrimony of the Church." 1 An officer in the chancery of the principal church of Ravenna was termed notarius in the sixth century. ${ }^{2}$

The ultimate approximation of the term notarius to tabellio, as both equivalent to the modern Notary, is placed in the period prior to the revival of the Civil law at Bologna at the beginning of the twelfth century. ${ }^{3}$

\section{(3) The Amanuensis and the Cancellarius.}

In the beginning of the sixth century the tabelliones were sometimes called amanuenses or cancellarii. ${ }^{4}$ As late as A.D. 804 a deed in regard to the protocoling of a mandate designates the Clerk of Court as amanuensis and not exceptor. ${ }^{5}$ In A.D. 578 the protocoling of a donation refers to the Clerk of the Curia as an amanuensis. ${ }^{6}$ The amanuenses apparently were slaves. ${ }^{7}$ The term cancellarius, like amanuensis, as we have seen, appears as late as the eighth and ninth century. ${ }^{8}$ For several centuries till the collapse of the Courts of the Counts in the ninth century, the Notaries attached to these Courts were known as palatine notaries and sometimes called cancellarii. In A.D. 508, one, Diaconus, the Clerk of the Curia, is styled amanuensis. ${ }^{9}$

The term domesticus seems also to have been used as equivalent to cancellarius, for it is ordained by the Interpretation of the Breviarium that a domesticus or cancellarius shall be chosen for every Judex by the principal officers of his Chancery. ${ }^{10}$

1 Ars notariatus (1740), p. 6.

2 Marini papiri, N. 74 (c. A.D. 575).

3 Vide Savigny, Geschichte des Römischen Rechts, and Chapter VIII. p. 48, infra.

4 Cod. Theod. ad L. Com. de falsis (ix. 19). Tabellio vero qui amanuensis nunc vel cancellarius dicitur. Vide also Du Cange, s.v. Cancellarius.

- See infra, p. 12.

- Savigny, loc. cit.

7 Servi amanuenses sunt qui notis, vel literis domini, vel alterius orationem jubente domino excipiunt, atque conscribunt. Cujac. Observ. Paul, iii. 8, § 73; 6, § 70. See also Serrigny, Droit public et administratif romain, 220.

${ }^{8}$ Cod. Theod. $l$. xi. 2 (Gothofred, $l$. xii. 3).

- Form. Mabillonii, b. 1 (Canc. iii. 469).

10 Cod. Theod. l. ii. 1. 


\section{(4) The Exceptor.}

The first point to be noticed is that the exceptor was distinct from the scriba, as writers at various periods have undoubtedly confused these two persons. The exceptor was at first a recognised private person, either a slave or hired for his services. ${ }^{1}$ In the fourth and fifth centuries the exceptor was recognised as a general term for a Clerk of Court; ${ }^{2}$ he was allowed certain fees, pro editione gestorum, ${ }^{3}$ although there seems to have been a difference of opinion as to whether the exceptor was a uniformly paid official of the State. ${ }^{4}$ In the Notitia Dignitatum ${ }^{5}$ exceptores uniformly occur in every Chancery and appear to have been attached to every Curia. ${ }^{6}$

According to a Constitution of Honorius, in legal proceedings before the Curia of a city, one magistrate, three principals, and the exceptor were required to be present. ${ }^{7}$ Valentinian III. states that three decurions and the exceptor are sufficient. ${ }^{8}$ Justinian $^{9}$ refers to the rights of the magistrates and the defensors but not of the decurions and the exceptor, but these omissions, as Savigny points out, are almost certainly because the presence of these officials was tacitly implied. ${ }^{10}$

1 Savigny, loc. cit. i. 51. Cod. Theod. l. 19, §9, de locati (xix. 2).

2 i.e. clerk of the Curia; Savigny, loc. cit. i. 52. Vide also Spangenberg, loc. cit., p. 43.

${ }^{3}$ l. $12, \S 1$. C. de prox. sacr. scrim. (xii. 19).

- Cod. Theod. l. 17, de div. off. (viii. 7).

5 The Notitia Dignitatum resembled an Almanac or Court Guide of the fifth century, which contained a description of all the territories of the Roman Empire and a list of all the public officials employed in the various spheres of administration. Vide edition published by Böcking (Bonn, 1839-53).

- Cod. Theod.l. 151, de Decur. Vide also J. A. Schmid, De Notariis Ecclesice. But note, as stated, that the exceptor, earlier than the fourth century, was universally understood to signify a private copier. Cod. Theod. $l$. 19, §9, de Locati.

7 Cod. Theod. l. 151, de decur. (1211) A.D. 396: Municipalia gesta non aliter fieri volumus, quam trium principalium prcesentia, excepto magistratu et exceptore publico.

${ }^{8}$ Repeated in Nov. Theod. Tit. 23: "In municipalium confectione gestorum sit firmitas, si apud tres curiales publico fuerit exceptore perscripta."

- l. 2. C. de Mag. Munic. (i. 56).

10 Savigny, loc. cit. i. 96. 
From the middle of the eighth century onwards for some time the exceptor of the Curia appears under his old or similar designations, though most frequently designed curialis: he was generally at the same time a tabellio. ${ }^{1}$ A deed of A.D. 721 is written by the Exceptor of the city of Placentia. ${ }^{2}$

\section{(5) The Pragmaticus.}

Gothofred ${ }^{3}$ says: "Pragmatici porro homines dicuntur, multo rerum usu periti et solertes, quasi advocatorum postici dicendorumque suggestores." Justinian " refers to "tabellionibus sive pragmaticis." In Greece, where they are first heard of, the pragmatici are called "expounders of law," 5 and Cicero speaks of them as being persons of low birth who prepared speeches for Counsel and specially notes that they do so for pecuniary benefit. ${ }^{6}$ Cicero uses the term "oratoribus," meaning the counsel who conducted the case in jure or in judicio. For the term orator, either causidicus, disertus, patronus or advocatus was sometimes used under the Empire. At that time the legal adviser who prepared the case was termed juris consultus, peritus, studiosus or pragmaticus. In the Republican period the advocatus was merely a friend or adviser of the litigant, while his pleader was termed orator or patronus. Afterwards, in Rome, the pragmatici seem to have exercised functions similar to those they performed in the East. Doubtless the fact that these functions lay mainly in

1 In Ravenna about A.D. 850 we find "Moyse Tabellionem et Exceptorem curice hujus civitatis Ravennae scribend. rogavi" (Marini papiri, N. 98, l.47, p. 314). For numerous examples of these designations and of the alternative term curialis, vide Savigny, loc. cit., i. 351.

2 Fumagalli, Cod. dipl., N. 1.

3 Digest, XLVIII. xix. 9, § 4: f.n. 7.

4 Digest, XLVIII. xix. 9 , § 4 .

5 Quintilianus: Inst. Orat. iii. 6, refers to "juris interpretes."

- "Apud Gracos infimi homines, mercedula adducti, ministros se prcebent in

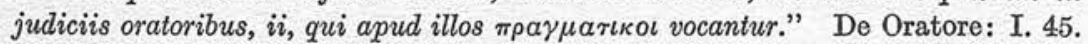
Gothofred (loc. cit. supra) quotes Juvenal (Satyr VII.): "Si contigit aureus unus, inde cadunt partes ex foedere pragmaticorum." 
preparing written speeches led them to be associated with the tabelliones as being also scribes. They, as well as the tabelliones, were entrusted with framing libelli and executing negotia forensia of a non-contentious character.

\section{(6) The Tabularius or Tabellarius. ${ }^{1}$}

There seems to have been considerable confusion amongst the early writers and commentators as to the exact functions of the tabularii, or, as they are occasionally called, tabellarii. They must be kept entirely distinct from the tabelliones, at all events in the first six or seven centuries A.D. According to Ars Notariatus, the tabularii were so called d tabulis, i.e. waxen tables; the office of the tabularius was to get from the debtors of the Fisc (i.e. the Treasury) obligations for paying debts due by the public and to make a record of them as also to state and balance the accounts belonging to the Fisc or to great cities: they were the same as our accomptants. It is certain, however, that their functions differed at different stages of history. At one time we find the tabularius referred to as a clerk to the tabellio, and referred to in that connection not only as tabularius but as amanuensis. ${ }^{2}$

Serrigny $^{3}$ says the term tabularius was frequently used to designate an employee of the Governor's office, and that he was a secretary charged with writing in the public registers.

The tabularii originally were slaves, for the office is declared by an Edict of Arcadius and Honorius in A.D. 401 to be restricted thereafter to freemen ${ }^{4}$ and Cujacius

I In addition to the authorities cited, vide Pfaff, "Tabellio und Tabularius," where Byzantine instruments are also specially considered, and also Du Cange: Gloss. VI.: Tabularii: (i) Servi pertabulas, seu per instrumenta chartarum manumissi; (ii) Qui tabulas publicas civitatum et rei vectigalis rationis tractant. Tabularium: locus ubi sedet notarius et acta ab ipso scripta servantur.

2 Vide Nov. XIIV. preface, Nov. LXXIII. § 7; Cujacius, Commentar. on Nov. LXXIII. infra, Appendix A, p. xxvii.

${ }^{3}$ Loc. cit. No. 811.

- "Generali lege sancimus . . . necessarii fuerint tabularii liberi homines ordinentur, neque ulli deinceps ad hoc officium patescat aditus, qui sit obnoxius servituti." Cod. X. $69 . \S 3$. 
writes "erat olim servile tabellarii officium." 1 Occasionally they were referred to as numerarii. ${ }^{2}$

Cujacius ${ }^{3}$ describes them as those "qui civitatum aut provinciarum chartas et rationes tractant atque supputant, qui prosunt tabulario civitatum in quo pleraque publica et privatorum recondūtur, veluti debitorum obsignatoe pecunice, quod ex multis locis liquet. . . . In rebus tamen privatorum plerumque adhibebantur, vel ut pro imperitis literarum scriberent aut subscriberent, vel ut pro stipulari nequeuntibus stipularentur, quasi personce publica, qua de re sunt multi loci, quos nolo notare."

Gothofred" similarly says "Tabularii pertinent ad ea quce publice inferuntur."

Justinian makes frequent reference to various functions of the tabellarius, of which we quote a few examples.

In regard to the duty of an heir to submit an Inventory in respect of his predecessor, Justinian enacts: ${ }^{5}$ Tutores, vel curatores, mox quam fuerint ordinati, sub prosentia publicarum [id est tabulariorum; Gothofred] personarum [in inventario heredis prceter tabularium tres requiruntur: Gothofred] inventarium rerum omnium et instrumentorum solemniter facere curabunt. Note, therefore, that the presence of tabularii is required when an Inventory is being completed and signed. One tabularius apparently will not suffice, for the plural is used, and therefore probably not less than two tabularii are essential. ${ }^{6}$

In the Institutes, ${ }^{7}$ under the title De adoptionibus, Justinian uses the phrase, in reference to an impubes,

\footnotetext{
1 Commentar. ad leg. clxxv.

${ }^{2}$ See Ars Notariatus, loc. cit. Also Bartolus, "Numerarii qui hodie tabularii appellantur." De Vet. Lib. XII. 62.

3 Commentar. ad Lib. X. Cod. Just. XXXI. 15.

- Note to Just. Cod. Lib. X. 59, 1; and vide note to Cod. Theod. Lib. VIII. 2.

5 C. V. $37,24$.

- $C f$. Ulpian, D. XXII. xii. 5: pluralis enim elocutio duorum numero contenta est. Further reference may be made to $C$. VI. $30,22, \S 2$, where specific reference is made to completion of the Inventory: nota fuerit ei [inventarium] apertura tabularum, . . . et hoc inventarium . . . impleatur sub prcesentia tabulariorum.

7 Inst. I. ii. § 3 .
} 
"adrogator personce publicce, referring undoubtedly to the tabularius, although Gothofred, it should be noted, considers "personce publicce" as equivalent to "magistratus."

Justinian makes special reference to the tabularii in connection with wills of blind testators. ${ }^{1}$ Blind persons can make a will "prosentibus septem testibus, quos aliis quoque testamentis interesse juris est, tabulario etiam [ut sint octo. Gothofred]: . . . sed et tabularii manu conscriptis sub obtentu septem testium, et eorundem testium manu subscriptis, dehinc consignatis tam ab eisdem testibus, quam à tabulario, plenum obtinebit robur testantis arbitrium, . . Sed quia tabulariorum copia non in omnibus locis datur qucerentibus: jubemus, ubi tabularius reperiri non possit, octavum adhiberi testem $;{ }^{2}$ ut quod tabulario pro supradicto modo commisimus, id per octavum testem effectum capiat. Seven witnesses are required if a tabularius is available: if no tabularius can be got, then an eighth witness must be found. ${ }^{3}$

Justinian again refers to the tabularius in connection with the resting-owing of a debt. In a dispute between a debtor and a creditor he says: Hoc modis omnibus necesse est eos prcesentibus tabulariis signare . . . attestatione videlicet prius per memoratos tabularios conscribenda. ${ }^{4}$

The tabularius, therefore, was a public person who performed his duties of drafting instruments, chiefly as a clerk to a tabellio, acting under a severe code of rules, but the documents which he drew up, or rather in which he co-operated in the drawing-up, had no public authority ${ }^{5}$ and required completion by the tabellio with the customary authentication and registration.

\footnotetext{
1 Cod. VI. 22, 8: Coecus an et quomodo testari possit.

2 Unus testis hic subrogatur in locum tabellionis (Gothofred).

3 Octo testes (si tabularius desit) requiruntur in caeci testamento (Gothofred).

4 C. VII. 72, 10.

5 Nov. XLIX. 2, 1.
} 


\section{CHAPTER III}

THE TABELLIO

The tabellio was the ancient equivalent of our modern notary. We have seen that the term notarius, which at first sight might seem to be equivalent to the term notary, refers during what might be termed the middle stage of his existence to an official who was attached to the Chancery, although at times performing certain duties which brought him under the general heading of a writer or scribe. We have also described the tabularius, noted his special characteristics and shewed that, although he carried through certain functions performed in a later age by the modern notary, the office is one distinct from that of the tabellio. The tabellio is therefore the person with whom we are principally concerned in tracing the origin and early history of the notary, though in the later centuries the terms tabellio, tabularius and notarius are used indiscriminately as meaning notary in the modern sense. ${ }^{1}$

Possibly the earliest trace of the use of the term tabellio appears in Ulpian. ${ }^{2}$ The expression used, "solet autem ita . . . interdici . . . tabellionibus," would seem to indicate that the office had been in use for a considerable time. That would place the origin of the office almost certainly in the second century. In a deed of gift made in A.D. 163 appears "Scripsi ego Aldicarius subdiaconus et Tabellio." 3 But the texts are of little assistance until the spread of writing and the necessity of having properly authenticated instruments brought the tabellio into the

1 Savigny, loc. cit.

2 De officio proconsulis, Lib. X.

3 See Mabillon, De re diplom. App. 98. 
forefront and invested him with more or less regular functions. That period might conveniently be dated from the end of the third century. ${ }^{1}$

The tabellio, according to Cujacius, ${ }^{2}$ " is est qui ex mandato partium contractus conscribit et partibus edit." The same writer further states: "Tabelliones sunt publici contractuum Scriptores vel testamentorum." 3 In his early days, unlike the tabularius and the scriba, the tabellio held no public appointment but usually prepared all private documents such as testaments, dispositions of land, etc., in effect was practically a professional scribe. ${ }^{4} \mathrm{He}$ was accustomed to conduct his business in the market-place or forum; hence the phrase instrumenta forensia. Their duties were regulated by law. ${ }^{5}$ They had in their service clerks, described as notarii, ${ }^{6}$ who took notes, as we have already stated, from which a formal document was drawn up, signed by the parties, attested by witnesses and authenticated by the tabellio. ${ }^{7}$ The tabularius also is frequently described as his clerk. 8 Brooke says: "The acts of a tabellio were styled instrumenta publice confecta and commanded a degree of credit and authenticity that was not accorded to instrumenta privata, or documents executed without the intervention of a tabellio. They were not, however, in Roman Law accorded the full credit and authenticity that attached to an official record." 9 These deeds were not, ipso facto, authoritative. To prove

${ }^{1}$ In A.D. 290. See C. viii. 4, 47.

2 Commentar., C. viii. 11, 17.

3 Commentar., Nov. XLIV., infra.

- As already noted, the tabellio at that time is sometimes called amanuensis or cancellarius, though the former term is usually applied to his clerk. Cuj. and Interp. l. 1, C. Th. ad L. Com. de falsis $(9,19)$.

5 Brooke, Office of a Notary, 8th ed., 3.

- Note this function of a notarius as distinct from his office as an official of the Chancery.

? Novel LXXIII, c. 7, describes the authentication of instruments (vide Appendix A, infra, p. xix.).

8 Vide f.n. 1, p. 14, supra.

'Brooke, loc. cit., 4. Vide Novel LXXIII. c. 5. Vide also Du Cange, Glossarium Med. VI., s.v. tabellio, etc., cf. f.n. 1, p. 14, supra; Lewis and Short, Latin Dict., s.v. tabellio, etc. 
them, if a dispute should arise, the tabellio or, if he was not available, the witnesses were called to prove, upon oath if necessary, the truth of the instrument in question. This could be avoided by registering the deeds, presumably with the Master of the Census, ${ }^{1}$ and then they became instrumenta publica confecta, and therefore as highly authoritative as they possibly could be. ${ }^{2}$ Failing registration, proof could only be established by the tabellio attesting their validity on oath, as we shall explain subsequently. The word tabellio itself appears to have been derived from the fact that the tabelliones used small tables, tabelloe, on which they wrote out their instruments, generally placed in some such place convenient to clients as the market-place or forum. The part played by the tabellio was important. $\mathrm{He}$ was largely responsible for deeds of all descriptions and also derived considerable importance as being, if called upon, a major witness of the transaction in question and certainly a valuable witness, apart from his notarial docquet, to identify the handwriting of a particular instrument if called upon. ${ }^{3}$ Since they were not public officials, as Serrigny says, ${ }^{4}$ therefore they could not confer an authoritative character on the deeds which they drew up. Yet they were persons of great importance, and to them in questions of dispute a judge inevitably had to turn.

It should be noted that already in the sixth century

1 Recording deeds with the Magister Census: vide Cujacius, Commentar., Nov. XLIV., infra. The Master of the Census was a city magistrate, called in a later age $\gamma$ puıkò, and the place where deeds were recorded was called $\tau \alpha \xi \in i o \nu$. In the provinces his place was taken by the defensor civitatis. Vide also p. 29, footnote 1, infra. "Already in A.D. 370 the students at Rome had been placed for disciplinary purposes under the Magister Census, who was a subordinate of the urban prefects (Cod. Theod. 14, 9, 1)." Jolowicz, Hist. Introd. to Roman Law, 470.

2 Vide Novel LXXIII.

3 Vide Novellæ XLIV. and LXXIII., infra, Appendix A.

${ }_{4}$ Droit public. et adm. rom., 190. Cf. Karlowa, Roemische Rechtsgeschichte, 1, 116; Die tabelliones waren keine Beamten mit publica fides, die von ihnen aufgenommen Urlounden hatten also nicht etwa dieselbe Beweiskraft, wie die von öffentlichen Beamten aufgenommen. Vide also Cujacius, Commentar., Novel LXXIII., infra, Appendix A, p. xxviii. 
the tabelliones in Ravenna and possibly in other important cities were formed into a schola or regular college, and also that the term forensis is used as a synonymous designation for tabellio. ${ }^{1}$

Some legal skill is required from the tabelliones, but not that degree necessary for juris-consults. In that respect they are on the same grade as advocati, pragmatici, formularii and tabularii. ${ }^{2}$

Savigny says ${ }^{3}$ that the tabelliones are the equivalent of our modern notaries, but, while this may apply to England and Germany, it certainly does not to Southern France, for there the notary has always had an official status and his deeds an official authority, always assuming he acted within the limits of the powers conferred on him and according to certain prescribed rules. ${ }^{4}$ In France Charlemagne was the first to invest notaries with the power of giving their deeds a character of public authority. In his "Capitularies" he calls them judices chartularii. In a capitulary of A.D. 803 he orders his legates to appoint notaries everywhere and two years later puts on every bishop, abbot, or count the obligation of having his private notary. The subsequent troubles in which France was involved prevented these wise measures from reaching fruition. It was reserved for St. Louis to set up a new order, though he seems to have been primarily concerned with Paris only. Formerly the office had been put up to public auction, but Louis created a special body of notaries and laid on them specific public duties.

In another sphere attention may usefully be directed

1 Marini papiri, N. 74: Primicerius Scholoe Forensium Civitatis Ravennatis seu Classensis.

2 Cujacius, Commentar., Nov. XLIV., infra.

3 Hist. du Droit romain du Moyen-Age, c. 2, § 16.

- Art. 1317, C. Civ. In regard to Northern France, vide Brinaud, Hist. du Droit Français, 1, 316. In Northern France, the notarial deed was not "authentic" until the seal of a Court was placed on it. The notary, in effect, was an assistant of the lay or ecclesiastical Court. Continental Legal History, i. $\S 14$. 
to the tabellio in Coptic law. ${ }^{1}$ In this connection it should be noted that the legal principles of Justinian were undoubtedly introduced into Egypt. ${ }^{2}$ A. Schiller ${ }^{3}$ has pointed out that over fifty deeds of sale, in the period of Coptic law which we are discussing, had only minor alterations in them, from which he logically, and prima facie correctly, deduces that the tabelliones responsible for them were following certain prescribed rules. ${ }^{4}$ Steinwerter ${ }^{5}$ has described the position of the tabellio in relation to formulce. Sufficient has been said to shew that the tabellio had a responsible position, even in Egypt where the Roman rule of that country (30 B.C.-A.D. 641) passed, in part, into Coptic law.

The instruments which the tabellio drew up, as we have seen, covered a wide range, and, if registered, had final authority. Instrumentorum nomine ea omnia accipienda sunt, quibus causa instrui potest: et ideo tam testimonia quam personce instrumentorum loco habentur. ${ }^{6}$ Their docquets applied to all probative writings whether drawn up by themselves or by such writers as a tabularius or a notarius, or even written by the parties themselves.

Here it may be convenient to consider the qualifications and duties of tabelliones before summarising in a separate chapter the general rules laid down by Justinian in regard to these officials.

1 "Coptic law" may be used for the period from A.D. 600 to A.D. 1000 as a convenient term for "Egyptian law." Though the Arabs completely conquered the whole of Egypt in a few years, they did not extend their influence over the native peoples to any appreciable extent till the persecutions, on religious grounds, of the tenth century. Vide Schiller, Juridical Review, xliii. 211.

2 Vide Taubenschlag, "Geschichte der Rezeption des Römischen Privatrechts in Aegypten," Studi in onore di Pietro Bonfante, vol. i. 367.

3 Juridical Review, xliii. 214.

4 The Coptic Law must have developed from Byzantine and for a summary of the Byzantine tabellio papyri reference should be made to P. Meyer, Juristische Papyri, p. 112.

${ }_{5}^{5}$ Studien zur Palaeographie und Papyruskunde, xix. 3.

- Paul., D. XXII. 4, 1. 


\section{CHAPTER IV}

\section{QUALIFICATIONS AND DUTIES OF THE TABELLIO}

Here we must be careful to distinguish between the tabellio and the notarius. As we have pointed out, ${ }^{1}$ confusion has frequently existed in regard to these functionaries. There is no doubt that in the period up to the sixth century the term notarius was limited to officials of the Imperial Chancery and for these officials there was undoubtedly a College of Notaries. Savigny says that in the sixth century the tabellions of Ravenna and also of other cities formed a proper college. ${ }^{2}$ At the time in question tabelliones and notarii were undoubtedly entirely different in function, duty, and responsibility. ${ }^{3}$ However it may be in regard to a distinctive College or Schola of the notarii, it is certain that the tabellionat could not be entered into without due regard to certain rules and qualifications. But so far as the College of Notaries was concerned, that seems an entirely different matter. Taking the College of the notarii first, we find Theodosius devoting an exhaustive title to the matter. ${ }^{4}$ The head of the College was the primicerius and his junior officials, secunderius, etc.

With regard to the Tabellions, their importance in the fourth, fifth, and sixth centuries led to a certain demand

\footnotetext{
1 Supra.

2 Loc. cit., c. V., § 106.

3 Supra. Distinction should also be made of purely Church notarii, vide Schmid, De notariis ecclesice, etc., Leip. 1756, 4.

- Cod. Theod., VI., X. In view of the difficulty of reference to this important matter, which is cognate but not essential to our subject, it has been thought advisable to reproduce this Title in Appendix B. An English Calendar has not been given as the material largely consists of references and the text of Theodosius, along with Gothofred's notes, is easily followed.
} 
for qualifications for the important duties they had to perform. According to Spangenberg, the general principles of a college of notaries with a primicerius and various subordinate grades were extended towards the tabelliones as well. ${ }^{1}$

A. Qualifications.

The essentials demanded from a tabellio were:

(1) Freedom.-A prospective tabellion had to be "free." Slaves and freedmen were strictly excluded. ${ }^{2}$

(2) Knowledge of Law.-It seems only natural that persons who had to deal with legal documents should themselves have at least a superficial knowledge of law. Ulpian makes this clear, "Solet autem ita vel juris studiosis interdici vel advocatis vel tabellionibus sive pragmaticis." 3 But this knowledge, according to Cujacius, was not of the high degree required from jurisconsults. ${ }^{4}$

(3) The Holding of certain other Offices or Employment.-This is a matter of standing in the order of "dignitas." The matter is a wide subject of study, but briefly it may be said that clergymen, for example, were excluded, ${ }^{5}$ as also were decurions. ${ }^{6}$

Assuming a person to be thus qualified, the election, or consideration of election, to the tabellionat seems to have belonged to the Master of the Consus ${ }^{7}$ in Rome and

1 Spangenberg, loc. cit., p. 43.

2 C. IX. $22 ; l .21, \S 2 ; c$. X. $33 ; l .1$ and 2.

s D. XLVIII. 19, l. 9, § 4.

- Vide Chap. III., supra, p. 20 and f.n. 2.

${ }_{5}$ C. XII. 1, $l .3$.

- In fact Justin I. laid down a penalty for any clergyman to display his judicial knowledge (C. I. 3, l. 40).

7 Magister Census : vide supra, pp. 19, 29, and Appendix A, p. vi. f.n. 4, 5. 
Constantinople, and to the defensores civitatis ${ }^{1}$ in the provinces.

\section{B. Duties.}

Granted successful admission to the tabellionat, it followed that a tabellio had to be available for consultation. In the works of Justinian ${ }^{2}$ in particular we find reference to the statio, which appears to have been the term used for the tabellion's place of business. This was generally situated near the Forum or the buildings containing the public or private archives. ${ }^{3}$ Sometimes the location is near some temple. ${ }^{4}$ The tabellio might be owner of the statio but might also be only a tenant, for Justinian refers to dominus stationis as distinct from the tabellio. ${ }^{5}$ Loss of statio, which was a punishment a tabellio guilty of misconduct or certain other irregularities might incur, has been held by some not to involve an infliction on the dominus if the tabellio was merely a tenant, ${ }^{6}$ but statio here, as Gothofred points out, ${ }^{7}$ is used as equivalent to munus. Another essential reason for a tabellio to have an office easily available for clients is the fact that a tabellio must be requested (rogatus) by intending contracting parties. ${ }^{8}$

It is an obligation on every tabellio to take up duty when asked, but he may employ a substitute, sometimes termed an adjutor, minister, amanuensis, or substitutus. ${ }^{9}$

\footnotetext{
${ }_{1}$ Defensor civitatis : vide supra, pp. 19, 29, and Appendix A, p. vi. f.n. 4, 5 .

2 Vide Nov. XLIV., c. 1, § 2.

3 Vide Spangenberg, loc. cit., D. 48, 19, l. 9, § 6.

4 Spangenberg, loc. cit.; Documenta Nos. 37, 54.

5 Nov. XLIV., c. $1, \S 2$.

6 Quoting as authority Nov. XLIV. c. 1, § 1 .

7 Vide Appendix A, p.iv, f.n. 2. But there may be doubt on this point. The main argument for loss of statio referring to loss of rank or position (mumus) is probably the fact that the tabellio need not necessarily have been owner of the statio (i.e. actual office of work). On the other hand the loss of rent of office may have been a serious deterrent.

s $C f$. modern Bar practice, where a barrister or advocate does not solicit work nor are professional lawyers permitted to advertise.

- Nov. XLIV. c. 1, §4. But this substitute (and he is only allowed one) must be approved by the Magister Census in the cities or the responsible defensor civitatis in the provinces: Gothofred, Appendix A, p. 6, f.n. 4, 5 .
} 
Failure to perform their duties was regarded as a grave and serious offence. It might involve loss of office, ${ }^{1}$ torture, mutilation, confiscation of property, fines, the loss in whole or in part of public confidence ("existimatio").

From the purely civil aspect the responsibility of the tabellio is not easy to determine. In the event of an error committed by a tabellio in drawing up a deed, the question seems to have been whether the error was a serious one or not. If the former, then the fault was treated as equivalent to fraud and the tabellio doubtless liable to prosecution by the aggrieved parties as well as to punishment on the criminal side. ${ }^{2}$ A slight error, however, was condoned as not being vital to the interests of any of the parties. It is pointed out by Bartolus ${ }^{3}$ in his Commentaries centuries later that the question is one of ability to correct. There are also cases where the tabellio is punished for failure to follow the statutory requirements: for example, failure to put the correct headings, etc., in the deed. ${ }^{4}$

It is almost certain that the tabellio could not be sued for bad legal counsel. While it is true he accepted fees, these were for work as a notary and not as a juris-consult, the standard of whose knowledge he was not supposed to possess. ${ }^{5}$ In testaments, according to Severus, a tabellio could not include a personal bequest to himself. ${ }^{\circ}$ But, in 480, an Edict of Zeno allowed a testator to leave a bequest to the tabellio for some legitimate reason. ${ }^{7}$

1 Examples are legion, e.g. a Tabellion making an illicit instrument: "Notarii qui faciunt instrumenta illicita sunt puniendi et ab officio removendi." Bartolus, Prim. Cod. de sacro. f. 25 (nu. 3).

${ }^{2}$ Bartolus, Dig. Vet. De Statu hom. f. 26. "Notarius quando non potest corrigere errorem suum, tenetur parti lasce." Vide p. 38 , infra.

3 "Notarius omittens ponere capitula et clausulas debitas in instrumento commisit falsum." Bartolus, Prim. Cod. De Epist.f. 30 (nu. 2).

1 Vide Chap. VI. infra.

5 Supra, pp. 20, 23.

6 . IX. 23, $l$. 3. This was forbidden under the penalties laid down in the Lex Cornelia.

7 C. VI. 23, 22. Cf. Bartolus, De Adoptionibus : Tabellio non potest conficere instrumentum de facto suo proprio. 
The tabellio was strictly debarred from drawing up instruments involving illicit matters. Such deeds were null and void $a b$ initio. ${ }^{1}$

As to fees, our information is largely derived from an Edict of Diocletian and Maximien in $301,{ }^{2}$ from which it appears that tabellions were paid recognised legal fees at the rate of so much for every hundred lines written by them. The penalty for over-charging was death. The exact amount payable the writer has failed to trace, and any modern authors who have dealt with the subject give varying amounts. Further, we do not know if these fees were treated like the "honoraria" of the Advocates.

C. Disciplinary Measures and Punishments.

These are laid down mainly by Ulpian and relate to prohibition to appear in Court, ${ }^{3}$ to draw up deeds and wills, ${ }^{4}$ the abolition of prescription in regard to forged deeds, and numerous penalties under special transgressions such as personal bequests ${ }^{5}$ under a will, alienation of Church property, etc.

1 C. I. 14, 5, § 1 (A.D. 439).

3 L. $9, \S 4$; D. XLVIII. 19.

5 L. $22 . \quad C$. VI. 23.
2 Edictum de pretiis rerum venalium.

4 Loc. cit., §§ 5, 7.

${ }^{6}$ L. 14. C. I. 2. 


\section{CHAPTER V}

\section{THE LAWS OF JUSTINIAN REGARDING TABELLIONS}

THe importance of the office of the tabellio is evidenced by the fact that Justinian thought fit to devote thereto two Novels (the 44 th and $73 \mathrm{rd}) .^{1}$ In these Novels certain principles are laid down with relevant matter concerning witnesses, and in particular the credence to be given to handwriting. There seems little doubt-and Justinian appears to have been strongly influenced thereby-that in the early days of writing scope was given to, and taken advantage of, by forgers to counterfeit handwriting, and to defeat such criminal objects Justinian laid down certain definite rules. Also it seems clear that Justinian realised the importance in private and in public life (particularly in commercial circles) of having some person who could be relied on to vouch for transactions between citizens and between traders, and in especial in connection with contracts and more particularly with testamentary dispositions, pledge, deposit, and transactions in regard to the transfer of property. The main points to be gathered from the Novels referred to ${ }^{2}$ are summarised as follows. These Novels in the Latin and English Calendar, with Gothofred's notes also translated, and the observations of Cujacius ${ }^{3}$ thereon also translated, are printed in Appendix A.

1 In addition in the Code and other Novels frequent reference is made and rules laid down in regard to the tabellio, witnesses, and other matters concerned with deeds. Reference has been made to these at the appropriate places in this text.

244 th and 73 rd Novels.

3 The observations of Cujacius on both the 44th and 73rd Novels are given in the original with a translation in Appendix A, infra. Cujacius, sometimes called Cujas, became Professor at Bourges about 1550. There he founded the historical School of Jurisprudence. Among the interpreters of Roman law in the Middle Ages, Cujacius held, by general acknowledgment, first rank. According to Hallam (Literature of Europe, ii. 72), such was his renown that, in 
Constantinople, and to the defensores civitatis ${ }^{1}$ in the provinces.

B. Duties.

Granted successful admission to the tabellionat, it followed that a tahellio had to be available for moncultation 
Failure to perform their duties was regarded as a grave and serious offence. It might involve loss of office, 1 torture, mutilation, confiscation of property, fines, the loss in whole or in part of public confidence ("existimatio").

From the purely civil aspect the responsibility of the tabellio is not easy to determine. In the event of an error committed by a tabellio in drawing up a deed, the question seems to have been whether the error was a serious one or not. If the former, then the fault was treated as equivalent to fraud and the tabellio doubtless liable to prosecution by the aggrieved parties as well as to punishment on the criminal side. ${ }^{2}$ A slight error, however, was condoned as not being vital to the interests of any of the parties. It is pointed out by Bartolus ${ }^{3}$ in his Commentaries centuries later that the question is one of ability to correct. There are also cases where the tabellio is punished for failure to follow the statutory requirements: for example, failure to put the correct headings, etc., in the deed. ${ }^{4}$

It is almost certain that the tabellio could not be sued for bad legal counsel. While it is true he accepted fees, these were for work as a notary and not as a juris-consult, the standard of whose knowledge he was not supposed to possess. ${ }^{5}$ In testaments, according to Severus, a tabellio could not include a personal bequest to himself. ${ }^{\circ}$ But, in 480 , an Edict of Zeno allowed a testator to leave a bequest to the tabellio for some legitimate reason. ${ }^{7}$

1 Examples are legion, e.g. a Tabellion making an illicit instrument: "Notarii qui faciunt instrumenta illicita sunt puniendi et ab officio removendi." Bartolus, Prim. Cod. de sacro. f. 25 (nu. 3).

${ }^{2}$ Bartolus, Dig. Vet. De Statu hom. f. 26. "Notarius quando non potest corrigere errorem suum, tenetur parti lass.." Vide p. 38 , infra.

3 "Notarius omittens ponere capitula et clausulas debitas in instrumento commisit falsum." Bartolus, Prim. Cod. De Epist.f. 30 (nu. 2).

1 Vide Chap. VI. infra.

5 Supra, pp. 20, 23.

6 $C$. IX. 23, $l$. 3. This was forbidden under the penalties laid down in the Lex Cornelia.

7 C. VI. 23, 22. Cf. Bartolus, De Adoptionibus : Tabellio non potest conficere instrumentum de facto suo proprio. 
The tabellio was strictly debarred from drawing up instruments involving illicit matters. Such deeds were null and void $a b$ initio. ${ }^{1}$

As to fees, our information is largely derived from an Edict of Diocletian and Maximien in $301,{ }^{2}$ from which it appears that tabellions were paid recognised legal fees at the rate of so much for every hundred lines written by them. The penalty for over-charging was death. The exact amount payable the writer has failed to trace, and any modern authors who have dealt with the subject give varying amounts. Further, we do not know if these fees were treated like the "honoraria" of the Advocates.

C. Disciplinary Measures and Punishments.

These are laid down mainly by Ulpian and relate to prohibition to appear in Court, ${ }^{3}$ to draw up deeds and wills, ${ }^{4}$ the abolition of prescription in regard to forged deeds, and numerous penalties under special transgressions such as personal bequests ${ }^{5}$ under a will, alienation of Church property, etc.

1 C. I. 14, 5, § 1 (A.D. 439).

3 L. $9, \S 4$; D. XLVIII. 19.

${ }^{5}$ L. $22 . \quad C$. VI. 23.
2 Edictum de pretiis rerum venalium.

${ }^{4}$ Loc. cit., $\S 5,7$.

${ }^{6}$ L. $14 . C$. I. 2. 


\section{CHAPTER V}

THE LAWS OF JUSTINIAN REGARDING TABELLIONS

THe importance of the office of the tabellio is evidenced by the fact that Justinian thought fit to devote thereto two Novels (the 44th and 73rd). ${ }^{1}$ In these Novels certain principles are laid down with relevant matter concerning witnesses, and in particular the credence to be given to handwriting. There seems little doubt-and Justinian appears to have been strongly influenced thereby - that in the early days of writing scope was given to, and taken advantage of, by forgers to counterfeit handwriting, and to defeat such criminal objects Justinian laid down certain definite rules. Also it seems clear that Justinian realised the importance in private and in public life (particularly in commercial circles) of having some person who could be relied on to vouch for transactions between citizens and between traders, and in especial in connection with contracts and more particularly with testamentary dispositions, pledge, deposit, and transactions in regard to the transfer of property. The main points to be gathered from the Novels referred to ${ }^{2}$ are summarised as follows. These Novels in the Latin and English Calendar, with Gothofred's notes also translated, and the observations of Cujacius ${ }^{3}$ thereon also translated, are printed in Appendix A.

1 In addition in the Code and other Novels frequent reference is made and rules laid down in regard to the tabellio, witnesses, and other matters concerned with deeds. Reference has been made to these at the appropriate places in this text.

244 th and 73 rd Novels.

3 The observations of Cujacius on both the 44th and 73rd Novels are given in the original with a translation in Appendix A, infra. Cujacius, sometimes called Cujas, became Professor at Bourges about 1550. There he founded the historical School of Jurisprudence. Among the interpreters of Roman law in the Middle Ages, Cujacius held, by general acknowledgment, first rank. According to Hallam (Literature of Europe, ii. 72), such was his renown that, in 
These translations are the original work of the author of this thesis, and where doubt has arisen as to the exactness of the translation, recourse has been made, not only to the various Latin renderings of Justinian, but also, where thought necessary, for exactitude, to the Greek original. ${ }^{1}$

\section{TH NOVEL}

(1) There had apparently been some slackness on the part of a notary which prompted this Novel. ${ }^{2}$ At the beginning of this Novel note the difference between the tabellio and the tabularius. ${ }^{3}$

(2) The importance of the notary is thus early recognised by the sanctions laid down, for

(3) Justinian enacts that "notaries are compelled by all means to be present at the execution of legal instruments, and unless this is done such instruments shall not be effective." 4

(4) If the law laid down in the 44th Novel is not observed, the notary who transgresses will lose his office. ${ }^{5}$

(5) An exception is made in the case of the Dominus Stationis, ${ }^{6}$ who must be held to be the landlord of the booth or office in which the tabellio conducted his business or else the possessor of the "office" and its accompanying revenues. ${ }^{6}$

(6) The excuse of illness or important business is not to be accepted as a pretext for any slackness or failure to

the public schools of Germany, when his name was mentioned everyone took off his hat. He died at Bourges in 1590. (A list of his principal works will be found in Lerminier, Introd. à l'Hist. du Droit, 2nd ed., p. 48).

1 Dr. Scott's recent translation of Justinian (and incidentally the first published English translation of the Novels) was not then available and indeed varies considerably in his interpretation of many important points.

2 44th Novel, Preface.

3 Vide Cujacius: Expositio, Novel XLIV., Appendix A, infra, p. xi.

"44th Novel, c. I., infra: Note that "legal instrument" here is really equivalent to "publica instrumenta confecta," for provision is made in the 73rd Novel (c. II.) for drawing up instruments of loan or deposit without a notary.

5 44th Novel, c. I. (1).

- Cf. 44th Novel, c. I. (3), Appendix, p. v; Cujacius, Appendix, p. xi, and Appendix E where "dominus stationis" is considered in detail. 
comply with the law. ${ }^{1}$ Emphasis is laid on the notary being a public official, and therefore his affairs come second to the State.

(7) To mitigate the severity of the foregoing subservience of private to public affairs, Justinian further enacts that the notary may appoint a substitute, who is to be formally authorised to act by the Master of the Census. ${ }^{2}$

(8) It is enacted that, though the law is violated by the notary employing other than licensed substitutes, the parties shall not suffer by reason of such illegality

1 44th Novel, c. I. (3) (Appendix, p. v), but according to Gothofred if the notary chances to be ill, he can complete the instrument by a substitute if he calls the contracting parties before him and they testify to the business in hand. This does not coincide with c. I., $\S 4$, of the 44th Novel, which permits of a substitute without such limitation; Gothofred emphasises this in his notes to the 44th Novel, c. I., Notes 1 and 2. But according to Cujacius (Expositio, Novel XLIV.): licebit tamen eis adjutorem, vel substitutem habere, et per eum contractus formare absolvereque partib. et per hunc quidem solum, non per alium quemlibet. Also see § 4, Appendix A, infra, p. v.

2 44th Novel, c. I., §4. Probari hic debet apud acta magistri census. Cujacius: Expositio, Novel XLIV., Appendix, infra, pp. ix, x. The Master of the Census was a city official, whom a later age termed $\gamma \rho v \iota \kappa \partial \nu \cdot L e o$, No. 44 . In the provinces this post was held by the "defensor civitatis." Justinian does not refer to the latter along with the Master of the Census, because a notary is only allowed an assistant or substitute in the City State on account of the vast number of transactions in the City State. The punishment of any other notary who, though an assistant or substitute, makes or completes an instrument is that he loses his office and it is transferred to him whose operations have been maltreated if he is a suitable person, or to any other suitable person (infra, pp.iv, $\mathrm{x}$ ). The defensores civitatum (plebis, loci) appear in the middle, or in the first half, of the fourth century. They must be distinguished from the Defensors of the Church, at first a clerical and later a secular office. The whole of the citizens, and not merely the Decurions, voted at this election. The Defensor's office lasted for five years and, after Justinian, for two years, but they were eligible for reappointment once only until their term of office came round again (Novel XV., Epilogue). Their main purpose was to occupy a position which afforded the citizens protection against the oppressions of the provincial governors (L. 4, C. de defens.). The Defensor was allowed an Exceptor and two officials. An appeal lay from him to the Governor. He had a certain amount of criminal jurisdiction. The Defensores gradually acquired under Justinian some magisterial rights (Novel XV.) and became Presidents of the Curia, but they only exercised magisterial rights when there were no other magistrates. All wills, donations, or other similar documents had to be registered by the Defensores (Novel XV. c. 3). The provincial cities had, in general, no magistrates and the Defensores supplied this want. Vide also Cujacius: De defensoribus civitatum. 
and their instruments shall be valid. The offending notary, however, is to be punished. ${ }^{1}$

(9) To further ensure accuracy and prevent fraud, it is enacted that-

(a) The instrument is to be written on that paper which contains the protocol. ${ }^{2}$

(b) There must be no cutting off the protocol or any loophole for fraud afforded in that direction. ${ }^{3}$

\section{RD Nover ${ }^{4}$}

(1) Owing to the numerous cases of forgery which had come to light, stringent rules are laid down regarding witnesses, handwriting, and for the special protection of illiterate persons.

(2) The contract of deposit appears to have been in wide use and was obviously one where extreme care was required. It is therefore enacted that, where there is denial by a party to the contract that the writing is his, another writing by him shall be produced so that the handwritings can be compared..$^{5}$ But this is not enough, and

(3) There must be three credible witnesses in the case of contracts of deposit before whom the instrument must be written and signed. 6

(4) To meet the case of persons who wish to keep private a loan or deposit, authority is given to dispense with

1 44th Novel, I. §4. The punishment is loss of office. Cujac. Observ., infra, Appendix, p. iv. But note: "notarius remotus ab officio potest vetcra instrumenta ante remotionem per eum confecta publicare et perficere. Bartolus: Dig. Vet. $f$. 38. De officio prcetoris.

${ }_{2}$ The protocol contained a statement of the name of Consul, time of writing, etc. Quid sit protocollum? See Cujac. Exposit. Novel XLIV., Appendix A, infra, p. xi. The Protocol is dealt with in Chapter VI, infra, p. 35.

3 The general practice was for notaries to draft their contracts and then engross them in mundum, i.e. on clean paper. Deinde redigunt eos in mundum . . . in chartam puram et hoc modo instrumenta complentur, absolvuntur, expediunturque partibus. Cujac. Exposit. Novel XLIV., Appendix A, infra, p. xi.

- Appendix, infra, p. xiii. 5 73rd Novel, I.

- Ibid. As to whether the notary is to be numbered as one of the three witnesses, see Bartolus: Cod. si cer. peta. f. 143. 
a notary, but there must be three credible and subscribing witnesses, ${ }^{1}$ a comparison of handwriting being insufficient of itself to establish credibility. ${ }^{2}$

(5) Where the evidence of handwriting and of witnesses conflicts, that of the witnesses prevails, but the decision lies in the hands of the judge as to which is more credible. ${ }^{3}$

(6) Where a party to an instrument relies on the evidence of handwriting alone, then the contract is voidable and he runs the risk of its being declared void. There is, however, a final appeal to the oath of the depositary. ${ }^{4}$

(7) The notary must state in his instrument that it has been executed in the presence of witnesses. ${ }^{5}$

(8) Where notes are appended to documents these should be used by the judge to assist him where there is doubt as to other comparison. ${ }^{6}$

(9) In a special chapter dealing with the comparison of handwriting, provision is made for cases where the witness or notary is dead or otherwise not available to testify. In such cases a comparison of handwriting must immediately be made, and, if the judge so desires, he can put the plaintiff on oath.?

(a) (a) Where instruments are made publicly and a notary is present, the notary can be called to give evidence on oath, but if he has employed a substitute 8 then the latter must come forward if he is alive, and only a reasonable reason such as illness can excuse him.

1 According to Julian (Const. 60, n. 234) it is immaterial if the witnesses have subscribed so long as the instrument has been completed in their presence.

2 73rd Novel, II.

${ }^{3}$ Ibid., III.

4 Ibid., IV. According to Gothofred the translation is corrupt and should mean as stated (Appendix A, infra, p. xvii, n. 7).

5 73rd Novel, V. Court decreets are, however, valid without witnesses: $l$. 3, C. de donation (vide Note by Gothofred, Appendix A, infra, p. xviii, n. 4). As to the notitia testium, see p. 42 , infra.

- Ibid., VI. TIbid., VII. The actual terms of the oath are laid down.

8 Notarius per substitutum potest subscribere. Gothofred, Appendix A, infra, p. $\mathrm{xx}$, n. 2 . 
( $\beta$ ) If an argentarius 1 is interested in such an instrument, he, too, shall give evidence, thus making three witnesses. ${ }^{2}$ If no argentarius was present, then the notary makes oath as to the credibility of the instrument. ${ }^{3}$

(b) If the notary is dead, then a comparison of his handwriting with that in other of his instruments must be made. Where neither tabellio or argentarius is available, then a comparison should be made of the handwritings of all concerned with the instrument.

(c) Where the only course is to compare instruments as to handwriting, then he who brings forward a document for comparison should take the customary oath, and he who has asked for a comparison should take an additional oath. ${ }^{4}$

(d) All this can be avoided if the parties have had the instruments publicly recorded. ${ }^{5}$

(10) ${ }^{6}$ Special rules are laid down for the protection of illiterate persons.

(a) In regard to written instruments,

(a) The witnesses must know the contracting parties. $^{7}$

1 Argentarii were those officials who were principally concerned with money deals, such as loans or deposits, and may possibly be best termed "bankers."

1 But as to the notary being counted as one of the witnesses, see note 6, p. 30, supra. Here, of course, it is a question of those present being found to supplement the evidence of the writing.

${ }^{3}$ But note that Cujacius holds that the presence of two witnesses or their subscriptions is required, and that the oath of the notary will not suffice. He, however, admits that matters will be different if the instrument has been formally recorded (Appendix A, infra, p. xxviii).

4 Both these oaths are to the effect that they have not been actuated by malice.

5 A recorded instrument has the highest authority: it must be believed in every respect. Gothofred, Appendix A, infra p. xxii, n. 5.

- 73rd Novel, VIII. With regard to wills of blind persons, Justinian insisted on seven witnesses and a tabularius. C. VI. $23,8$.

7 Testis instrumentarius potest reprobari, si ignotus sit contrahentibus. Gothofred, Appendix A, infra, p. xxiii, n. 5. 
(b) There must be not less than five witnesses, ${ }^{1}$ including he who drew the instrument entirely or who wrote for those who were illiterate.

$(\beta)$ In such cases, where anyone wishes to make a contract without writing, there must be witnesses or a reference to oath to establish credibility. ${ }^{2}$ This only applies to contracts of deposit where one pound of gold ${ }^{3}$ [or under] is concerned.

(11) ${ }^{4}$ With regard to oral contracts and also wills made by persons outside the City State, the system then in use is to continue, in view of the scarcity of writers and witnesses in the provinces and of the illiterate state of the country people. ${ }^{5}$ n. 6 .

1 Tabellio scil. tabularius ejus, et tres testes. Gothofred, Appendix A, p. xxiii,

${ }^{2}$ A contract without writing can be proved by witnesses or oath. Jul. num. 242.

3 I.e. 72 solidi.

4 73rd Novel, IX.

5 Certain solemnities are waived. Gothofred, Appendix A, infra, p. xxv, n. 1. As to wills made by country people, see $l$. 31 , c. de testam. 


\section{CHAPTER VI}

\section{THE DRAWING-UP OF INSTRUMENTS}

WE have already noticed (Chap. IV.) the general rules laid down by Justinian, but beyond these there is a vast amount of material available, particularly in Spangenberg, ${ }^{1}$ to which reference can easily be made. Our endeavour has been to select what is essential to our particular sphere of study.

The Materies, Modus Scripturce, Forma externa, et Lingua are sufficiently expounded by Spangenberg ${ }^{1}$ to need little further attention here. It is scarcely within the province of a work of this kind to investigate the substance of paper, writing, or ink ${ }^{2}$ which was used. We are naturally more concerned with the actual format of the Instruments.

\section{(A) The Scheda or Rough Draft.}

This was the essential preliminary to all notarial deeds. The contracting parties first gave a rough and brief outline to the tabellio, or more generally to his assistants (ministri), of the contract or agreement which they desired to be put in legal shape. ${ }^{3}$ This scheda or draft had no legal significance or value: it was, in effect, a memorandum from which the tabellio drew up the final deed. Until what was termed the "Translatio in Mundum" was made and duly executed, the wishes of the contracting parties were of no legal value. ${ }^{4}$

1 Spangenberg: Juris Romani Tabula Negotiorum solemnium. Leip., 1822, p. 12 et seq.

2 In 470, a Constitution of Leo reserved the use of purple ink for the Emperors under severe penalties for transgression. It may be noted that all deeds in Scotland after $1712 \mathrm{had}$ to be on stamped vellum. Prior to that there was no legal necessity for them to be on parchment or paper. Office of a NotaryPublick, 54.

- Vide L. 17 pr. c. IV. 21; Novel LII. c. 2. 


\section{(B) The Contents of the Instrument.}

The tabellion must necessarily be requested by the contracting parties to take up the task of embodying their wishes in a deed. ${ }^{1}$

The subject-matter of each deed naturally depended on the wishes of the parties in relation to the special circumstances of the contract or agreement into which they were entering. But there were certain specific features to which observance had to be paid:

(1) The date.

(2) The names of the contracting parties and their qualifications. ${ }^{2}$

(3) A declaration that the parties contracted of their own volition and that their civil capacity entitled them so to contract.

(4) A statement regarding in what way the transaction embodied in the contract was to be carried out, e.g. traditio, mancipatio, etc.

(5) A definite designation of the object of the contract.

(6) Any special clauses or conditions, e.g. dolus.

(7) The designation of the tabellion.

(8) A general form of conclusion: Bene valete, etc. ${ }^{3}$

(C) The Writer of the Instrument.

There is no doubt that this was a matter for the tabellion or his assistant. ${ }^{4}$

(D) The Protocol. 5

This contained, inter alia:

(a) The name of the magistrate in the area where the deed was executed.

(b) The date when the paper was made. ${ }^{6}$

\footnotetext{
1 Hence the contracting parties were frequently called rogatores; Brunner, Zur Rechtsgeschichte der Römischen und Germanischen Urkunde.

2 Vide Spangenberg, loc. cit., p. 31 et seq.

3 This was, of course, entirely optional, but a study of the deeds in Spangenberg (loc. cit.) shews that there was frequently an expression of this kind.

- Vide Novel LXXIII. c. 7, § 1.

5 Vide Novel XLIV., Preface, Appendix A, infra, p. i, and Gothofred's note 2. The protocol was not allowed to be cut off from the rest of the deed. Nov. XIV. c. 2 , infra. 'Vide Cujac. Expositic, Novel XIIV., Appendix A, p. xii.
} 
(E) The Language.

Towards the end of the fourth century A.D. Greek and Latin were used indiscriminately, but in the Courts Latin seems to have been preferred. ${ }^{4}$ In ordinary practice, also, Latin seems to have mainly been used. ${ }^{2}$ Ulpian $^{3}$ states that Latin must be used in testaments under penalty of nullity, ${ }^{1}$ but in practice Greek is frequently found intermingled with Latin. ${ }^{4}$

\section{(F) The Date.}

This generally comprised three things:

(1) The name of the ruling Emperor and the year of his reign.

(2) The name of the Consul or Consuls acting at the time.

(3) The Indiction-stating the month and the year.

Justinian himself lays down the form to be used in this example: "Imperii Justiniani sacratissimi Augusti et Imperatoris anno II post consulatum Flavii Belisarii clarissimi viri anno 2. die autem tot, et tot, Kalend." 5

1 "Judices tam Latina quam Graca lingua sententias proferre possunt" (C. VII. 45, L. 12; cf. Novel XLVII. c. 2).

${ }^{2}$ Cf. Spangenberg, loc. cit., pp. 22-24.

3 XXV. $\$ 9$.

- Vide Novel XLVII. c. II.: "Those who use . . . ancient and uncertain characters shall . . . be obliged to write after them others which are familiar to all." Vide Spangenberg, loc. cit., Docs. Nos. 18 and 30, infra, Appendix C.

5 Vide Novel XLVII. c. I. § 1: "The name of the Emperor shall be placed at the head of all public documents and the date shall be clearly written in Latin characters." . . " Wherefore we order that all those officials employed in drawing up documents or decisions, no matter where this may be, and that the notaries who in compliance with certain rules draw up various instruments in this Great City or in other parts of the Empire ... shall begin as follows: 'The year of the reign of the Most Holy and August Emperor' and afterwards insert the name of the consul for that year and then the indiction, month and day. . . ." Permission is given to the inhabitants of the East and other provinces who are in the habit of earmarking the date of documents by relating them to the date of the foundation of their cities to add that latter statement after the three requisites referred to have been stated. Vide Spangenberg, loc. cit., and specially Deeds Nos. XXXI., LII., LIV., and LVI. Vide also Appendix D, infra, p. xlviii. 


\section{(G) Seal and Subscriptions.}

Instruments were thoroughly safeguarded by sealing. ${ }^{1}$ The imposition of the seal or sign of the witnesses or parties also required that it should be stated whose seal it was which was placed on the wax. That in effect means that the signatories placed their subscriptions opposite their seal. Apart from the witnesses, as a rule those who asked for the preparation of the documents signed. But the practice appears to have varied, and special rules were laid down from time to time in connection with such specialties as Wills, Deeds of Sale, etc. ${ }^{2}$ Justinian made special provision for the case of a contracting party being illiterate ${ }^{3}$ and in the case of blind persons. $^{4}$

Frequently in ancient instruments the sign of the Cross $(\dagger)$ appears beside or close to a signature of a subscribing party or witness. According to Spangenberg, ${ }^{5}$ the use of the cross was often merely an expression of

1 Mere signatures were not considered sufficient: the supreme test was "sealing": to be certain, both methods were generally used. The sealing was probably recognised as more important in view of the few people who could write. "Obsignatione claudebatur instrumentum per impositum sigillum." Vide Spangenberg, loc. cit. 39 , f.n. 1 .

2 Reference may be made to C. IV. 21, L. 17; to Marcien (D. 48, 10, L. 1, § 8) who distinguishes "special" and "general" subscriptions. Distinction should be drawn between subscriptio and superscriptio. The latter was mainly in use in testaments but also is to be found in other deeds, notably deeds of gift and sale. The nature of these superscriptions is evidenced in instruments cited by Spangenberg (vide Appendix C). A good general account of the early history of wills and witnesses is available in Maine, Ancient Law, chap. vi. et seq. According to Maine, the first appearance of sealing in the history of jurisprudence, considered as a mode of authentication, is that of the attachment of the seal of each of the seven witnesses to a will subject to the Prætorian Court (loc. cit.). Further, it should be noted that these early seals were more than an index of the presence or assent of the signatory and were in fact actual fastenings which had to be broken before the instrument could be read.

3 Novel XLIV., infra, p. iii; Novel LXXIII., C. 8, infra, p. xxiii. The case of an illiterate testator is provided for by a rescript of Theodosius II. and Valentinian III. in 439 (C. VI. 23, L. 21) requiring an eighth (i.e. one additional) witness.

4 C. VI. 23,8 .

5 Loc. cit., p. 37. 
religious feeling, ${ }^{1}$ but we also find Justinian definitely enacting ${ }^{2}$ that every illiterate heir must draw a cross at the foot of the Inventory which he had to draw up before the subscription of the tabularius, and this practice was not confined to Inventories but was in general use ${ }^{3}$ where the parties were unable to write.

\section{(H) The Completio and Absolutio.}

An instrument was finally completed, after having been drafted, approved, and subseribed by the witnesses, by the Tabellion making the final statement. We find in practically every deed the words Complevi et absolvi or a similar phrase involving tenses of complere et absolvere. The authorities differ in opinion ${ }^{4}$ as to the exact relationship of the completio and the absolutio, but so far as we are concerned there is little to consider in that regard as affecting the Tabellion, who seems to have been sufficiently stereotyped in procedure as to recognise that some such phrase was essential to identify his docquet. ${ }^{5}$

\section{(I) Errors and Corrections.}

A word in regard to these may not be out of place. Erasures or corrections or additions did not affect the requirements of the law, but logically raised the question of good faith. ${ }^{6}$ Thus, in testaments especially, investigation had to be made as to whether such changes were made at the wish of the testator or "were caused undesignedly by

1 Symbole pieux. Giry, Man. de Diplom., p. 594.

2 C. VI. 30, l. 22, § 2.

3 Vide Spangenberg, Documents Nos. 28 et seq.

- Vide Bethmann-Holweg, Der Roemische Civilprozess, note 28; Bruns, Die Unterschriften in den Römischen Rechts-Urkunden, p. 128.

- Numerous examples will be found in Spangenberg, loc. cit., with a detailed account of the Completio and Absolutio (pp. 36-41). Cf. C. IV. 21, L. 17.

- Legitimate erasure was allowed even up to modern days. Two notaries' knives, or erasers, of Florentine work, of the sixteenth century, were exhibited at a meeting of the British Archrological Association in 1865. A reference to erasures or alterations was required in the notary's docquet just as in our testingclause in modern Scots deeds. Cf. Rebuffi, Praxis Beneficiorum, p. 160. 
another, or are to be attributed to the fraudulent act of someone else." 1 The author of any such unauthorised change incurred the penalties laid down by the Lex Cornelia de falsis. ${ }^{2}$ According to Bartolus, writing in a later age, the omission of any of the recognised solemnities raised an irrebuttable presumption of falsehood. ${ }^{3}$ Where, however, an error occurs in an essential solemnity such as the omission of the date or name of consul the matter can be rectified by obtaining judicial authority. The question turns on the length of the time between the application to the Court and the time when the deed was actually made. In no circumstances will authority be given where a lengthy period has elapsed. ${ }^{4}$ Finally, an error on the part of a notary, which cannot be rectified apart from penal responsibility, renders him liable for any loss occasioned to a contracting party. ${ }^{5}$

1 Rescript of Diocletian and Maximilian: C. VI. 23, L. 12, § 1.

${ }^{2}$ D. 48 : 10, L. 2 . Vide p. 26, supra.

s Omissio solennitatis in instrumento inducit prcesumptionem falsitatis, contra quem non videtur admitti probatio. Sup. Authent. De Tabell. f. 24.

" Dig. Vet. f. 26. De Statu hominum. Cf. "timeousness" in modern law.

s Ibid. 


\section{CHAPTER VII}

\section{EVIDENCE}

THE proof of the authenticity of instruments, other than those acta publica confecta which held a unique position owing to being registered, depended entirely on witnesses, allied with a comparison of handwriting.

\section{(a) Witnesses.}

In the pre-Justinianian period there was considerable flexibility in estimating evidence. Oral testimony was largely accepted and even hearsay evidence was admissible. Presumptiones juris et de jure were absolute, and presumptiones juris were not redarguable unless by strong contradictory evidence. The rules laid down by Justinian effected a considerable change. "Contra scriptum testimonium, non scriptum testimonium non fertur" is laid down in the Code, ${ }^{1}$ and we have, on the authority of Paul, ${ }^{2}$ "testes cum de fide tabularum nihil dicitur adversus scripturam interrogari non possunt," but in practice parole evidence was admitted to contradict a written instrument or a suspected forgery. These rules apply in varying degrees according to the type of document concerned. Here, of course, we are concerned primarily with instrumenta. ${ }^{3}$

${ }^{1}$ C. IV. l. 20, § 1. $\quad{ }^{2}$ Paul, V. l. 15, § 4. Vide Karlowa, loc. cit., 1, 996.

3 Instrumentum is defined by Bartolus as a public writing, i.e. a notarial writing as distinguished from a private deed: Opera, vii. 112; in the Code, 2, 59, Lugduni, 1555 , fol. The term used for a private deed is litera. In Scots practice litera was always used as relating to non-notarial deeds, e.g. Litera Venditionis, Letters of Indenture, etc., but the term was used in the Civil and Canon law as a general term for all formal deeds. Cf. Devoti, Jus canonicum, iii. 56 (Rome, 1837), and Burge, Commentaries on Colonial and Foreign Laws, ii. 699. 
The general situation may be thus briefly summarised:

(1) Only "free" persons could act as witnesses, but the testimony of a witness alleged to be a slave must be received pending an inquiry into his status. ${ }^{1}$ In wills especially must a witness be free (Ulpian, $l .20,7 ; D .28,1, \S 6,1$, n. 10).

(2) A witness must be of unblemished reputation. ${ }^{2}$ Those of low social rank, if suspect in any respect, may be put to the torture. ${ }^{2}$ Jews are expressly excluded where either party to a document is an orthodox believer. ${ }^{3}$

(3) A witness must have reached the age of puberty. ${ }^{4}$

(4) Insane persons can only testify in lucid intervals. ${ }^{5}$

(5) Interdicted spendthrifts cannot testify. ${ }^{6}$

(6) Witnesses to the payment of a pecuniary debt evidenced by a written instrument shall not be selected by chance. ${ }^{7}$

(7) Testimony shall be reduced to writing. ${ }^{8}$

(8) A witness shall not be produced a fourth time when what they testify to is already known. ${ }^{9}$

(9) A witness shall only be examined in his own province and the locality in which he is summoned. ${ }^{10}$

(10) A witness may be excluded from testifying on the ground of enmity to either of the parties. ${ }^{11}$

(11) Mediators between litigants are not allowed to testify unless with the consent of the parties. ${ }^{12}$

(12) The witnesses are to appear in presence of the parties. ${ }^{13}$ This applies to any instrument whatsoever. $^{14}$

(13) The witnesses must be known to the parties. ${ }^{15}$

${ }^{1}$ Novel XC. c. 6 ; cf. VI. 23, l. 1. $\quad{ }^{2}$ Ibid., c. 1. $\quad{ }^{3}$ C. I. v. 21, pref.

4 A law of Julia de vi forbade an impubes to be a witness (D. XXII. 5, l. 3, §5). Vide also $C$. VI. 23, $l$. 21, pref., regarding wills and minor witnesses.

5 D. XXVIII. $1, l .20, \S 4$.

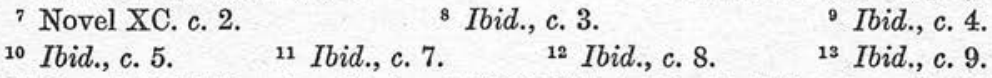

${ }^{6} D$. XXVIII. $1, l$. 18, pref.

14 Novel LXXIII. c. 1. Cf. also C. VIII. 8, l. 4; Novels LII. c. 2, and XCVII. c. 4.

15 Novel LXIII. c. 8. 
(14) The witnesses must be of the orthodox Christian religion. ${ }^{1}$

(15) The parties in the cause and all having a direct interest in it as, for example, guarantors, were debarred.

(16) The number of witnesses required varied. Thus, where the contracting parties were literate, three witnesses were demanded; ${ }^{2}$ but if the parties were illiterate, five were necessary. ${ }^{3}$ In the case of wills, seven witnesses were essential, and, if the testator was illiterate, eight. ${ }^{4}$

(17) The witnesses had to sign immediately after the parties, just as in modern practice. That meant just before the completio. ${ }^{5}$ One frequently finds after the completio a list of the names of the witnesses and their quality. ${ }^{6}$ This notitia testium was undoubtedly written by the tabellio as a help to keep trace of the witnesses in the event of any dispute arising in connection with a deed.

(18) Witnesses and sign of the Cross $(\dagger) .^{\text {? }}$

(19) Witnesses incurred no obligation by acting as such except to give evidence on oath if necessary, when called upon to testify to their signature and the genuineness of the proceedings. ${ }^{8}$

\section{(b) Witnesses, Comparison of Handwriting ${ }^{9}$ and Oaths.}

Just as in modern practice handwriting experts are called in to decide as to similarity or identity of writings, so in Justinianian times stress was laid on an adequate establishment of the genuineness of the writing as being

${ }^{1}$ C. I. 7, $l .3$; I. $5, l .21 . \quad 2$ Novel LXXIII. c. 1.

${ }^{3}$ Ibid., c. 8, pref.

- C. VI. 23, l. 21; vide p. 37, f.n. 3, supra.

5 Novel LXXIII. c. 5.

- Vide Spangenberg, loc. cit., No. 18, and a similar notitia testium is given in Nos. $30,37,38,45,49,54$, and 55 , which evidences its common use in instruments of gift, sale, etc. (Vide Appendix C, infra.)

7 Vide Chapter VI. (G), supra.

- Cf. C. VI. 23, l. 21, § 2.

- See also Chapter V. p. 30, supra. 
that of a particular person, the result, Justinian emphasises, ${ }^{1}$ of numerous cases of forgery. This led, in effect, to the sanction of a double method of proof: evidence by witnesses and proof by comparison of writings.

The first witness was the tabellio who was responsible for the instrument, ${ }^{2}$ and, if he did not actually write the document himself, then the clerk or substitute who acted for him must testify unless prevented by some severe illness or similar excuse. If an adnumerator was present, then his evidence is also to be taken. This gives the requisite three witnesses. ${ }^{3}$ Cujacius, on the other hand, does not accept the evidence of the tabellio alone, ${ }^{4}$ and if an amanuensis and argentarius (i.e. the adnumerator of Justinian) were not present, he requires other two witnesses: "A tabellio of himself is not sufficient as a witness nor is a notarial instrument in Court its own evidence." He goes on, however, to except instruments recorded with the Master of the Census, the City Magistrate, or the defensor civitatis as being by registration "public evidence" (publicum testimonium). ${ }^{5}$

The effect of this recording-which compares with our Scots system of registration in the various Registers of Deeds-was to confer on such deeds the high authority of instrumenta publica confecta and, in effect, to relieve the tabellio of all further responsibility in their connection except in so far as he might be summoned to add additional or confirmatory support to their tenor or effect.

From a perusal of authorities, ${ }^{6}$ it appears that a summary or recitatio, together with a complete copy of the deed, was lodged in the register of the appropriate

1 Novel LXXIII, pref., Appendix A, p. xiii., infra.

2 Ibid., cap. vii. § 1. infra.

'Novel LXXIII. Cap. VII. § 1. Gothofred's note 5, Appendix A, p. xx.,

Expositio: Novel LXXIII, Appendix A, p. xxvii., infra.

5 Ibid.

- Girard, Savigny, Maynz. 
official having the jus acta conficiendi. No restriction seems to have been placed on the deeds which could so be registered with the exception of certain exemptions laid down by Justinian and including all mortis causa deeds and certain deeds relating to donations. ${ }^{1}$ Obviously special rules were designed for testaments which were not opened ${ }^{2}$ until after the testator's death. ${ }^{3}$ The witnesses, or at all events as many of them as possible, had to be present at the opening of the will to acknowledge their seals. Thereafter the will was read, copied, and, after being sealed with a public seal, was lodged in the public register. ${ }^{4}$

Where the notary has died, there must be a comparison of his handwriting, ${ }^{5}$ and where the person who drafted the deed (i.e. the clerk of the tabellio) and the adnumerator are also both not available, there must be a comparison of all the handwritings including that of all who subscribed.

The collatio instrumentorum necessitated, in accordance with the usual practice, that the person producing the document for comparison had to take the customary oath. $^{6}$ He who asked for a comparison had to take an additional oath that he was not actuated by malice or guilty of any device whereby the truth might be concealed. ${ }^{7}$ It is interesting to note that the juramentum in litem, $j$. suppletorium and $j$. voluntarium were incorporated into

${ }^{2}$ Vide C. VIII. $56, l .4 ; 53, l .34 ; 53, l .36, \S 3 ; 53, l .34$, § 1; C. V. 12, l. 31, pref. and $\S 1$.

2 Literally so, as the seals and bindings had to be broken (rupto lino).

3 Cf. Paul, IV. 6, § 3.

- Ibid., IV. 6, § 1: "Tabulce testamentarice aperiuntur hoc modo, ut testes, vel maxima pars eorum adhibeatur, qui signaverint testamentum, ita ut, agnitis signis, rupto lino, aperiatur et recitetur; atque ita describendi exempli fiat potestas. Ac deinde signo publico obsignatum in archium redigatur, ut si quando exemplum interciderit, sit, unde peti possit." Cf. C. VI. 3; D. XXIX. Vide Spangenberg, loc. cit., I., XIV., Gesta de aperiundis testamentis habita.

5 Novel LXXIII. Cap. VII. § 2.

- For form of oath, vide Novel LXXIII, Cap. VII., pref.; cf. C. IV. 21, 19.

? For form of oath, vide ibid., Cap. VII. § 3, ibid. 
our Scots judicial system. ${ }^{1}$ All this can, of course, be escaped by utilising the system of registration of deeds. ${ }^{2}$ Justinian is really primarily concerned with private instruments and particularly with cases where the parties were illiterate. In the latter case we have seen that a further safeguard was instituted by requiring five witnesses ${ }^{3}$ instead of the customary three.

Nothing is laid down as to what writings are to be utilised in a collatio instrumentorum, but it is surely certain that instrumenta publica confecta would have greater weight than private instruments, and accordingly would be used wherever possible. It would hardly be possible that a tabellio would not have some of his deeds registered and these would naturally be selected, attention always being paid to the variation in handwriting owing to increasing age or illness on the part of the writer or a difference in the style of pen or kind of ink. ${ }^{4}$

Justinian further enacts that, where the written instrument differs from the oral evidence of witnesses, the greater weight is to be given to the viva voce evidence, but that the final decision shall lie in the prudence and conscientiousness of the judge. ${ }^{5}$ This confirms the inclusion in the Code of the dictum of Diocletian and Maximien in A.D. 299.6

Severe penalties were laid down for those giving false testimony. These varied in Justinian's Digest according to the status of the persons, whether they were honestiores,

1 Cf. Dickson on Evidence, II. iv. 1; V.iii.; VI. 1; III. 1, XV.; and le serment décisoire; le serment in litem; and le serment déferé d'office (Civil Code, 1357-1369).

${ }^{2}$ Novel LXXIII. Cap. VII. § 3. Instrumentum insinuatum magnae authoritatis est : ei namque creditur omnimodo: Gothofred.

${ }^{3}$ Doubtless the tabellio, his clerk, and three witnesses. Gothofred, Note 6 to Novel LXXIII. Cap. VIII.

4 Novel LXXIII. pref.

5 Novel LXXIII. Cap. III.

- C. IV. xix. 12: Dominium ut probetur: Cum res non instrumentis gerantur, sed in hac rei gestce testimonium conferatur, factam emptionem, et in vacuam possessionem inductum patrem tuum, pretiumque numeratum, quibus potes, jure proditis probationibus docere debes. 
humiliores or tenuiores, or servi, and might consist of exile, death, or beating with rods. ${ }^{1}$ Certainly, in the case of a guilty tabellio, loss of office followed immediately. ${ }^{2}$ A prosecution for the crime of forgery was not barred by prescription unless twenty years had elapsed. ${ }^{3}$

1 Cf. Paul V. § 15; Novel XC. c. 1, § 1.

2 Vide p. 25, supra.

s $C$. IX. xxii. 12. With regard to the prescription of crime, $c f$. the recent ease of Sugden decided by the High Court of Justiciary, 1934, S.L.T. 465. 


\section{CHAPTER VIII}

\section{CONCLUSIONS}

We have endeavoured to trace the office of the Notary from the earliest time records are available until the end of the sixth century. Shortly thereafter occurred a period of "darkness" until the revival of law with the school at Bologna in the eleventh century. ${ }^{1}$ From the thirteenth to the sixteenth centuries the "glossators" and their successors flourished and laid the foundations of a more complete revival of Roman law. In this period the notarius - the equivalent of the earlier tabellio - carried through the functions laid down by Justinian with addenda necessitated by the growth of international trade. Indeed a major part of the office of the notarius lay in certifying documents relative to the "law merchant."

In the sixteenth century the science of theoretical law passed to France, where in 1550 we find Cujas at the head of Roman law teaching at Bourges. ${ }^{2}$ In the seventeenth

1 Irnerius is generally, and we think rightly, recognised as the founder of the school of law at Bologna, where his lectures, in 1120 and successive years, attracted the awakening intelligence of jurists. The teachings of the Bologna lecturers spread over Europe and it is noteworthy that at Oxford, in 1149, Vacarius, a disciple of the Lombard school, gave lectures in Roman law. The Bologna school saw the growth of the "glossators," whose successors were the "scholastic" lawyers, of whom the most notable were Odofredus, Bartolus and Baldas. Of these Bartolus has left probably the most notable of the earlier commentaries on the Civil law. Bartolus was born at Sassoferrato sometime between 1309 and 1313. He studied in Perugia (then a notable school of law with which he was closely associated all his life). After attending the school at Bologna he graduated "doctor" in his twenty-first year. In 1339 we find him expounding law in Pisa, where he was a member of the College of Rainerius whose pupil he had been at Bologna. Thereafter he returned to and lectured at Perugia, where he died in 1357. Vide Savigny, loc. cit., VII. 137.

${ }_{2}$ Cujas, vide Chapter V. p. 27, f.n. 3, supra. 
and eighteenth centuries the centre of Roman law teaching lay in France and the Netherlands, Leyden and Utrecht (where many Scots jurists studied) competing for distinction with Bourges and Toulouse, until the sway of influence again reverted to France with the juristic omnipotence of Pothier. Finally, the most notable figure of pre-moderns was Savigny in Germany, who has so frequently been quoted as an authority in these pages. Reference also might possibly be made to Heineccius, whose influence in Germany in the eighteenth century was outstanding.

From the middle of the eighth till the end of the thirteenth centuries it is definite that one uniform legal system prevailed in Ravenna, Rome and Naples. ${ }^{1}$ So far as our special subject is concerned, tabellio retained its original meaning-in effect more as a profession and a business than as a public office. Savigny tells us ${ }^{2}$ that "the old corporate constitution of the Tabellions had survived without any interruption, and the Prototabellio, ${ }^{3}$ occasionally mentioned, is the president of this incorporation, and the same person with the Primicerius ${ }^{3}$ of preceding times or with the Major ${ }^{3}$ of the thirteenth century.

Notarius was still, as in the earlier centuries, peculiar to certain officers in the Chancery of the Church of Ravenna, who might also be tabellions. ${ }^{4}$ This distinction, however, gradually disappeared and notarius became the general term as among the Lombards. ${ }^{5}$ This notarius is

1 Savigny, loc. cit., I. 348.

2 Ibid., I. 319. Cf. Fantuzzi, IV. 347: "In A.D. 1227 some persons, not members of the constituted body, attempted to carry on the business of Tabellion; but a judgment of the Archbishop sustained the exclusive rights of the Incorporation, over which a major was then, and for the future, appointed to preside."

3 "Apollenaris in Dei nomine Proto Tabellio hujus civitatis Ravenne": A.D. 977, Fantuzzi, I. 195. Cf. Appendix B, infra.

- "Ego Ubaldus Ravenne Tabellio, et Notarius Sancte Ravennatis Ecclesie Scripsi": A.D. 977, Fantuzzi, I. 195. Vide Chapter II. pp. 10-11, supra.

5 Vide Savigny, loc. cit., p. 398. Note the recurring expression notarii civitatis. It would seem that it was in Lombardy that the terms notarius and tabellio first commenced to be synonymous. 
the direct forerunner of the notary in Scots, English and French law. "The old exceptor," continues Savigny, "often occurs under that or similar designations." 1

There seems little doubt that the office of Notary retained practically all its Justinianian features in the "Dark Ages" of law until we are able to resume more detailed information from the jurists of the Bologna school and their successors. ${ }^{2}$

A comparison of Roman notarial instruments with the earlier Scots notarial instruments (of which one, dated 1500 , of Alexr. Myln, subsequently a President of the Court of Session, is reproduced as a frontispiece to this thesis), shews that the intrinsic features of the former are reproduced in the latter. ${ }^{3}$ This is a subject for examination beyond the scope of this thesis, but sufficient has been said to substantiate a direct link of Civil law with the early law of Scotland in a most important sphere.

Finally, reference should here be made to Dr. Maitland Thomson's erudite work on The Public Records of Scotland, and in particular to his account of the Notary, which should prove invaluable for continuation of this study. ${ }^{4}$

1 Vide Chapter II. (4), p. 13, supra.

$2 C f$. the account given by Montesquieu (Roman Law in Mediceval Europe, at p. 50) regarding the notary and witnesses in connection with a dispute in Lombardy as to the genuineness of a charter, in the time of Guido of Spoleto (A.D. 889), from which it is evident that Justinian's law was recognised in all its authority.

${ }^{3} C f$., for example, the Indictio. For a comparison of the solemnities in Civil law and Scots law notarial instruments, vide Appendix D, infra, p. xlviii. This really belongs to a continuation of this thesis, but is adduced as substantial evidence that even in these pages sufficient has been stated to prove a direct connection between the notarial system of the Civil law of Rome and that of the early law of Scotland. The exact method and period of "reception" remains to be stated and vouched for.

4 Vide also Miller, "The Place of Scotland in the History of Roman Law," Juridical Review, xxxvii. at p. 165; and Murray, Legal Practice in Ayr and the West of Scotland, where valuable details are given from early protocol books in that district. 


\section{APPENDICES}

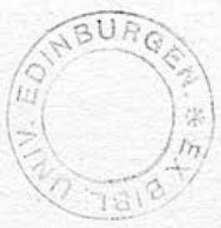


APpendix A.

Novel XLIV. of Justinian . . . . . . .

Commentary thereon by Cujacius . . . . . ix

Novel LXXIII. of Justinian . . . . . . . . xiii

Commentary thereon by Cujacius . . . . . xxvii

(All with Latin and English Calendar)

APPENDIX B.

Code of Theodosius, Lib. VI. Tit. X. (De Primicerio et

Notariis) . . . . . . . . $\mathrm{xxx}$

Appendix C.

Selection of Instruments (Spangenberg) . . . . . xli

(1) Testamentum sollemne Mannanis . . . . xli

(2) Fragmentum Instrumenti donat. Gaudioso . . xlv

(3) Instrumentum donat. Stephani Græci . . . . xlvi

(4) Instrumentum donat. Sisiveræ . . . . xlvii

APPENDIX D.

Extract from Ars Notariatus . . . . . . . xlviii

Appendix E.

Extracts from Schöell's Latin Version of Novels XLIV. and LXXIII. 


\title{
APPENDIX A
}

\author{
Novel XLIV. OF JUSTINIAN (with Gothofred's notes) . \\ Commentary thereon by Cujacius . . . ix \\ Novel LXXIII. of JUSTINIAN (with Gothofred's notes) xiii \\ Commentary thereon by Cujacius . . . xxvii
}

\author{
TIт. XXIII.
}

\section{DE TABELLIONIBUS ${ }^{1}$ ET UT PROTOCOLLA ${ }^{2}$ DIMITTANT IN CHARTIS. ${ }^{3}$}

\author{
Novella Constit. XLIV.
}

\section{Imperator Justinianus Augustus Ioanni prcefecto pratorio, iterum exconsuli \& patricio.}

\section{PRAEFATIO.}

LITEM paulo ante audivimus præsenti legi præbentem occasionem.

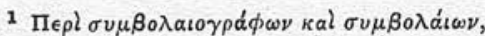
22. Ecl. 2. De tabellionibus \& eorum fide Jul. const. 40 . Porro tabelliones sunt publici contractuum transactores, l. 14. \&. 3. C. de sacr. eccles. l. 17. Cod. de fid. instrum. $l$. 2. Cod. de Eunuch. l. 1. Cod. ut nemo ad suum pat. \& testamentorum perscriptores. l.24. C. de testam.

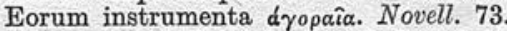
adde $l .21$. Cod. ad $l$. Cornel de fals. $l$. 15. Cod. de decurionib. iidem tabularii

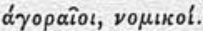

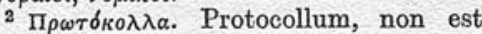
major \& regia charta velut quidam opinantur: nec est scheda negligentius scripta: Non est etiam exemplar formularum, quo tabelliones uti solent: sed brevis adnotatio, quæ declarabat quo Comite largitionum, (sub cujus cura erant chartariæ,) quo tempore \& à quo præparatæ fuissent chartæ. Ex eo arguebantur sæpe falsitates, qua \& ratione Cujac. refert Lutetiæ accidisse, ut Senatus suspectum chirographum arguerit, ex die in eo adscripto quo nondum ejus notæ (Galli la marque) charta ulla erat in rerum natura. Et hac ratione vetat Justinianus ex chartis abscindi protocolla. Item instrumenta in aliis chartis scribi, quam in his, quæ protocolla habeant. Jul. num. 175. \& cap. 2. j. eod.

3 In instrumentis, Index Regina apud Cujac.
TItLe XXIII.

\section{CONCERNING NOTARIES 1 WHO MUST HAVE PROTO- COLS $^{2}$ IN THEIR PUBLIC DOCUMENTS. ${ }^{3}$}

\section{Forty-Fourth Novel (New Constitution).}

The Emperor Justinian to John, Prcetorian Prefect, Twice Consul and Patrician.

\section{PREFACE.}

We have recently heard of a dispute which is the reason for enact-

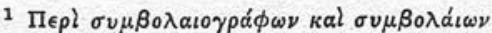
=Concerning notaries and their instruments. $22 \mathrm{Ecl}$. 2. Eod. Jul. const. 40 . Formerly notaries were transactors of public contracts, seq. eod.

$2 \pi \rho \omega \tau \delta \kappa \circ \lambda \lambda \alpha=$ Protocols. The protocol is not a great and ruling document as some suppose, nor is it a carelessly written paper, nor is it a species of style which the notaries were wont to use, but a short preface, which sets forth under the authority of what Count of the Treasury (who had charge of such charters), at what time and by whom the charter was prepared. From that falsehoods were often proved and for this reason Cujacius stated that it happened at Paris that the Senate convicted a suspected chirograph, because no paper of that mark was then in existence. For this reason Justinian forbade the protocol to be cut off from the document: likewise he forbade instruments to be written on pages other than on those which contained the protocol. Jul. eod.

${ }^{3}$ In documents, eod. 
Ex persona quidem mulieris cujusdam ferebatur documentum ${ }^{1}$, literas quidem ejus non habens ${ }^{2}$, (erat autem harum ignara) completum autem à tabellione ${ }^{3}$ \& tabulario, subscriptionem ejus 4 habens, \& testium ostendens præsentiam: deinde dum quædam dubitatio

I* super eo fieret, muliere dicente, non esse à se delegata ${ }^{5}$ quæ charta loquebatur: qui litem audiebat, quærebat ${ }^{6}$ à tabellione cognoscere negotii veritatem: denique tabellionem deduxit ${ }^{7}$ : at ille literas recognoscere dixit completionis ${ }^{8}$ tabellionis, non tamen nosse aliquid horum quæ secuta sunt, ${ }^{9}$ nec enim sibi ab initio penitus delegata, sed commisisse cuidam suorum hoc facere: neque postea venisse ad completionem, sed rursus alii hoc commisisse, \& is quidem qui affuit completioni, venit, nibil nec ipse dicens se nosse: etenim neque scriptor fuit documenti, sed solum docuit, quia præsente se hoc dimissum sit, nec cui ab initio

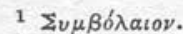

3 Non perscriptum ejus manu.

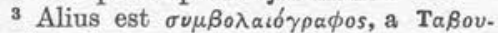
$\lambda a p i o v$. Instrumentum enim hic profertur completum à tabellione, subscriptum à muliere tabularii manu, ut Novell, 73 .

4 Aìrर̂s, id est, mulieris.

${ }^{5} \mathrm{E} \pi เ \tau a \chi \theta^{\theta}{ }^{\prime} \nu \tau \alpha$, id est demandata.

6 Hinc colligunt notarios non sponte, sed ad id rogatos debere instrumentum conficere. arg. $l .25$. ff. de procurat. cap. 12. vers. Te igitur. extr. de privileg. Ans.

${ }^{7} \mathrm{H} \gamma \alpha \gamma \in \nu$, id est, in judicium deduxit.

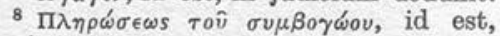
perfecti instrumenti.

9 Id est, tabellio fatebatur se nosse instrumentum completum esse, se tamen ignorare, quid inter contrahentes postremo convenisset, allegabat: nec enim se integrum instrumenti initium conscripsisse, sed ejus compositionem demandasse suorum alicui, id est, discipulo vel ministro: vel se alteri ejusdem instrumenti completionem commisisse, $l$. 17. Cod. de fid. instrum.

* See Appendix E, p. 1. ing this law. An instrument, ${ }^{1}$ bearing to be that of a certain woman, but which was not written by her ${ }^{2}$ (as she could not write), had been completed by a notary ${ }^{3}$ and by his clerk, who had assisted the women's signature, ${ }^{4}$ and bore evidence of the presence of witnesses. Subsequently doubt arose as to the credence to be given to the document, the woman saying that the instrument contained certain things which did not convey her instructions. ${ }^{5}$ The judge who heard the case attempted to obtain ${ }^{6}$ the true state of affairs from the notary, who appeared in Court ${ }^{7}$ and said that he recognised the handwriting of the completing ${ }^{8}$ but did not know what the parties agreed to ${ }^{9}$ because the document had been executed by one of his clerks and he himself was not present at its completion. The clerk, having been summoned to Court, because the document had been executed in his presence, said

$1 \Sigma v \mu \beta \delta \lambda \alpha \iota \nu=$ instrument.

2 Not written in her handwriting.

${ }^{3} \sigma v \mu \beta o \lambda \alpha i \delta \gamma \rho \alpha \phi o s:$ the tabellio is a different person from the tabularius. For the instrument is produced completed by the tabellio and subscribed by the woman with the aid of the tabularius;seeNovel73.

${ }^{4}$ A virîs, that is, of the woman.

5 Things ordered, i.e. instructions.

6 Hence they take it that notaries should not proffer their services but ought to be asked when instruments are to be made.

$7 \mathrm{H} \gamma \alpha \gamma \in \nu$, that is, brought into Court.

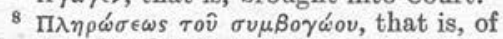
the completed instrument.

9 That is, the notary acknowledged that he knew that the instrument had been completed, but, nevertheless, alleged that he was ignorant of what the parties ultimately agreed on: for he had not written the whole of the instrument from the beginning, but that its compilation had been delegated to his clerk or assistant: that he commissioned the completion of the instrument to another, $l .17$, Cod. de fid. instrum. 
delegatum est, inventus est: unde nisi per testes judex valuisset II * agnoscere causam pure, periculum patiebatur, undique cadendi negotii notitia. Et illud quidem competentem meruit examinationem atque decretum.

\section{CAP. I.}

Nos autem credimus oportere universis auxiliari, \& communem in omnibus facere legem: quatenus præpositis operi tabellionum, ipsis per se omnibus modis injungatur ${ }^{1}$ documentum, ut dum dimittitur ${ }^{2}$ intersint: \& non aliter imponatur chartæ completio, nisi hæc gerantur: ut habeant unde sciant negotium, \& interrogati à judicibus, possint quæ subsecuta sunt cognoscere, \& respondere, maxime quando literas sunt ignorantes ${ }^{3}$ qui hæc injungunt ${ }^{4}$ : quibus facilis est \& inconvincibilis denegatio horum quæ pro veritate secuta sunt.

1 Sensus est: Cuilibet contractui tabellionem ipsum per se præesse \& interesse debere. Interesse inquam, ab initio ad finem usque, nec ante complementum instrumento adponere, quam norit $\tau \dot{\eta} \nu$ vं $\pi 0 \theta \epsilon \sigma \nu$, id est, negotium de quo agitur.

2 Tabelliones ipsi per se convenire debent instrumenta composituri: neque aliter instrumentum absolvere, nisı causas cognoscant, ut interrogati à judice, id de quo agitur, tuto ac certe referre possint.

3 Id est tune maxime cum contra-

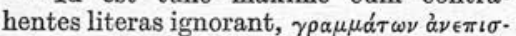

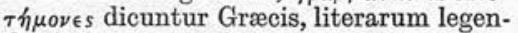
darum \& scribendarum ignari, qui ne scavent ni lire ni escrire.

4 Instrumenti ad substantiam pertinere hinc colligunt, ut tabellarius de eo conficiendo sit rogatus: alias non præsumi rogatum. Idque putat Rolandus à Valle motus communi interpretum opinione 1. cons. 38, n. 4. \& 1. cons. 44. $n$. 25. 32. 33. 34 .

* See Appendix E, p. 1. that he was not the writer of the instrument, nor could the person by whom it had been dictated from the beginning be found. Hence, unless the judge could ascertain the truth from witnesses, the position is precarious, and all knowledge of the business done is uncertain. And so the matter has deserved our thorough investigation and this decree.

\section{Chapter I.}

WE, indeed, consider it behoves us to aid our citizens and to institute a universal law: whereby it is enacted that notaries must by all means be present ${ }^{2}$ when legal instruments are being executed, ${ }^{1}$ and unless this is done, the instruments shall not be expedited, so that the notaries may have means of knowing the business in hand and, if subsequently questioned in Court, may be aware of what has occurred and be able to answer questions, particularly where the parties who order ${ }^{4}$ the instruments have been illiterate, ${ }^{3}$ under which circum-

1 The meaning is, that for all contracts the notary himself should be present and preside. I say, he should be present from the beginning to the end, and not complete the instrument unless he knows the circumstances, i.e. the matter which is being transacted.

2 The notaries themselves ought to be present at the drawing up of instruments: not only to complete the instrument, but that they may know the circumstances, so that, if questioned by the judge about what was done, they may, safely and with certainty, testify.

3 That is especially when the contracting parties are illiterate, as the

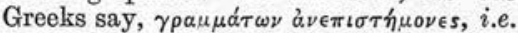
ignorant of reading and writing, qui ne scavent ni lire ni escrire.

4 Hence they take it that it belongs to the substance of the instrument that the notary has been asked to make the instrument, otherwise he is not presumed to have been asked. Thus Roland à Valle thinks, influenced by the common opinion of the translators. 
§. 1. Ut ergo omnia hæc prohibeamus, propterea præsentem conscripsimus legem: \& hæc custodiri modis omnibus volumus à tabellionibus, sive in ipsa felicissima civitate, sive in provinciis sint: scientibus, quia si præter hæc aliquid egerint, cadent ${ }^{1}$ omnino iis quæ vocantur stationibus ${ }^{2}$ : \& qui ${ }^{3}$ ab eis dirigitur ad injungendum ${ }^{4}$ documentum, \& interest, ipse dominus super stationis auctoritate erit, ${ }^{5} \&$ mutabitur causa: \& ille quidem de cætero hoc obtinebit officium in statione, quale qui in ea primatum tenebat: ille vero cadet ea: aut unus erit ministrantium illi: quoniam ille quidem dedignatus est hoc agere, quod erat concessum ei: ille vero secundum illius voluntatem hoc egerit, propterea nos hanc intulimus eis pœnam, ut optimi fiant circa documenta, \& justi, \& cau-

III * tiores, \& non propter suam requiem $\&$ delicias corrumpant alienas vitas. $\S .2$. Si vero indignus sit forte potestatem in stationibus suscipere, is ${ }^{6}$ cui documentum extra ea quæ à nobis disposita sunt per præsentem legem, injungitur, tabellio quidem cadat omnibus modis hac causa: alter $^{7}$ vero pro eo constituatur:

1 Poena tabellionis in hanc legem committentis.

2 Id est munere. Hic enim statio pro munere accipi videtur, quod majus est quam officina.

3 Is est qui vocatur à Juliano cap. 174. discipulus tabellionis.

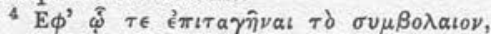
ad perficiendum instrumentum.

${ }_{5}$ Pcena tabellionis qui per discipulum aut exceptorem sive notarium, non per se instrumenta format, stationis amissio, cætera hic vide.

- Tabellio.

7 Discipulus nimirum tabellionis.

* See Áppendix E, p. 1. stances it is easy and incontestible for them to make a denial of the truth of what actually happened.

$\S 1$. In order, therefore, that we may prevent such things, we have drawn up the present law and wish it to be observed in every way both in this most fortunate City and also in the provinces. And it is to be known that if any notary should violate it in any way, he shall certainly lose ${ }^{1}$ his office, ${ }^{2}$ and he ${ }^{3}$ who is instructed to see to the document being executed, ${ }^{4}$ and is present, shall be substituted for $\operatorname{him}^{5}$ and shall undertake the duties of the office, just as his superior originally did, because he had neglected to carry through what was entrusted to him and had not acted according to the wishes of the parties, and accordingly we decree this punishment of these [notaries] so that they may be exceedingly careful, proper and cautious about documents, and not waste the substance of others on account of their own convenience and pleasure.

$\S 2$. If, therefore, on ${ }^{6}$ is proved to be unfit to conduct his office, the notary for whom the document is completed shall, in addition to other things laid down by us in this law, lose his office entirely and another ${ }^{7}$ shall take his place,

1 The punishment of a notary infring. ing this law.

2 That is, in their employment. For here statio appears to be taken for munus, which is greater than officina.

3 That is, he who is called by Julian, cap. 174, the apprentice of the tabellio.

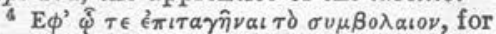
the completion of the instrument.

5 The punishment of the tabellio who makes an instrument, not by himself but by his clerk or scribe or copyist, is loss of office.

6 The notary.

7 Without doubt, the clerk of the notary. 
nihil omnino damnificando ex hoc stationis ${ }^{1}$ domino quicunque fuerit extraneorum, \& non ipse tabellio, neque cadente lucris exinde venientibus: sed illo solo qui talia perpetravit, \& dedignatus est suum complere opus, primatu cadente: omnibus quidem aliis super stationis jure integris dominis ejus ab ipsis tabellionibus qui talia peccaverunt, servandis. \$. 3. Et non fingant tabelliones occasiones, per ægritudinem forte discedentes, aut occupationes hujusmodi: licebit enim eis, si quid tale fuerit evocare ${ }^{2}$ eos qui contrahunt, \& per se causam complere: proinde hæc quæ contingunt raro, ${ }^{3}$ non impedimentum facient universis, eo quod nihil inter homines sic est indubitatum, ${ }^{4}$ ut non possit (licet aliquid sit valde justissimum) tamen suscipere quandam solicitam dubitationem, sed nec quæstus eorum minores fieri per hoc, propter contrahentium frequentiam occasionem habentes: cum melius sit pauca ${ }^{5}$ agere caute, quam multis interesse periculose. §. 4. Ut tamen non vehementer eis dura lex esse

1 Interdum alius est stationis dominus, alius tabellio.

2 Tabellio, licet ægrotus sit, per substitutum instrumentum formare non potest: sed ad se contracturos evocare debet, \& ab eis causam integram audire. Possis etiam colligere, non ideo instrumentum reprobari, quod confectum fuerit à tabellione ægroto.

3 Vid. l. 3. 4. 5. 6. ff. de legib.

${ }^{4}$ Nihil ita certum est, ut non possit controverti deque eo quodammodo dubitari.

5 Utilius est pauca tuto agere, quam multa cum periculo.

* See Appendix E, p. 1 . but the dominus stationis shall not IV * be penalised in any way, ${ }^{1}$ if he is a layman and not himself a notary, nor shall he lose any benefits thereby, but he alone shall be punished who has committed these misdeeds and has failed to carry through his duty, for the rights of the domini are not affected by the sins of notaries.

$\S 3$. And notaries shall not contrive to be absent on the ground of illness as a pretext or some other occupation, for if some such thing should happen they can summon ${ }^{2}$ the contracting parties and complete the business with them personally; whence, as such cases rarely ${ }^{3}$ happen, no obstacle should be made to public business in that there is nothing so certain ${ }^{4}$ amongst men that it cannot (even if it be exceedingly just) yet cause some punctilious doubt to arise; but the fees of notaries will not be reduced because of this law, since they have many opportunities of drawing up contracts, and it is better to carry through a few ${ }^{5}$ things with care than to embark rashly upon many things.

$\S 4$. In order, however, that this law may not seem to notaries to be

1 Sometimes the dominus stationis and the tabellio are different persons.

2 The tabellio, if he chances to be ill, cannot complete an instrument through a substitute: but ought to call the contracting parties before him and to hear the whole affair from them, and if the affair is so transacted, you may also infer that the instrument is not invalidated merely because it was completed by a notary when he was ill.

3 Eod.

4 Thus nothing is so certain that it cannot be disputed and therefore to some extent doubted.

${ }^{5}$ It is more useful to conduct a few transactions with safety than many with danger. 
videatur, nos conjicientes ${ }^{1}$ humanam naturam mediocres ${ }^{2}$ etiam eis leges nostras ponimus, propter tales enim eorum forte dubitationes damus eis licentiam singulis unum ${ }^{3}$ ad hoc constituere (gestis ${ }^{4}$ apud clarissimum $^{5}$ magistrum census ${ }^{6}$ felicissimæ civitatis $^{7}$ solemniter celebratis) \& licentiam ${ }^{8}$ ei dare, ut delegentur ei $a b$ iis qui veniunt ad ejus stationem \& documenta, \& dimissis ${ }^{9}$ eis interesse: \& nulli omnino alteri in statione existenti, licentiam esse, ut aut delegetur ei initium, aut cum dimittuntur, intersit: nisi tabellioni qui auctoritatem habet, aut qui ${ }^{10} \mathrm{ab}$ eo ad hoc statutus est. $\mathrm{Si}$ vero V* præter hoc fiat, \& alter delegetur : tunc subjacet pœnæ tabellio, qui

1 Id est, oculis conjectis intuentes humanam naturam.

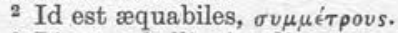

3 Licet tabellioni adjutorem \& substitutum habere, \& per eum contractus formare absolvereque partibus: in statione tamen.

4 Tabellio, substitutum quidem habere potest, sed unum tantum eumque probatum in urbe à magistro census: ut hinc constet, liberam substituti probandi facultatem tabellionibus, fuisse, liberam inquam, hoc est sine confirmatione magistri census: ut in provinciis, apud defensores civitatis.

5 Tabelliones igitur fuere in dispositione \& cura magistri census in ipsis urbibus regiis: ut in provinciis sub cura defensoris civitatis.

6 Posterior ætas hunc magistratum

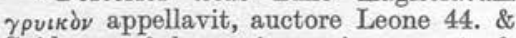
Suida: ut \& locum ipsum in quo acta \& insinuationes fiebant, quod \& Cedreno in

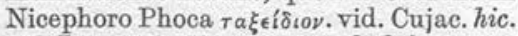

7 In provinciis vero apud defensorem civitatum.

8 Sensus est: Substitutum tabellionis, mandato contrahentium instrumentum posse complere in sua statione, posse etiam ejusdem instrumenti complemento interesse.

9 Id est, que absolvendis interessent.

10 De eo jam dictum est.

* See Appendix E, p. li. too severe, we, realising ${ }^{1}$ human nature, have placed these moderate ${ }^{2}$ rules on them, and on account perchance of doubts arising, we grant them authority to appoint each one ${ }^{3}$ a substitute (by a proceeding in the usual form ${ }^{4}$ before the noble ${ }^{5}$ Master of the Census ${ }^{6}$ of this most fortunate City ${ }^{7}$ ) and to give the substitute authority ${ }^{8}$ to receive instructions and documents from those who come to his office and are present at the execution of the instruments, ${ }^{9}$ but certainly to no other person shall authority be given to whom matters may be delegated in the beginning or by whom the business may be expedited, except to the notary indicated or his substitute who ${ }^{10}$

1 That is, with understanding eyes, estimating human nature.

2 That is, equitable.

3 The notary can have an assistant and substitute, and can make a contract through him and complete them for the parties: yet he must be in office.

4 The notary is able to have a substitute, but one only, and he to be approved in the city by the Master of the Census. Hence it is plain that notaries formerly could employ substitutes without the approval of the Master of the Census, or, in the provinces, of the Defensor civitatis. [See Chapter V. p. 29, supra.]

5 The notaries therefore were under the guidance and care of the Master of the Census in their own royal cities, while in the provinces they were under the care of the Advocate of the State.

6 In a later age, this magistrate was called $\gamma$ pvicos by authority of Leo 44 \& Suida: eod. [See Cujac. Expositio, Novel xliv., Appendix, infra.]

\footnotetext{
7 In the provinces by the Defensor civitatis.

8 The meaning is: the substitute of the notary, by his authority is able to carry out in his office the execution of the instrument and to be present at its execution.

9 That is, who are present at their issuing.

${ }^{10}$ It has already been stated regarding the substitute.
} 
auctoritatem habet à nobis dudum definitam: ipsis tamen documentis propter utilitatem contrahentium non infirmandis. Novimus enim quia legis metu de cætero \& ipsi custodient quæ à nobis decreta sunt, \& documenta sub cautela facient.

CAP. II.

$V t$ tabelliones in protocollo describant, idque cum die \& consule.

ILLUD quoque præsenti adjicimus legi, ut tabelliones non in alia charta pura ${ }^{1}$ scribant documenta, nisi in illa quæ in initio (quod vocatur protocollum ${ }^{2}$ ) per tempora gloriosissimi comitis sacrarum nostrarum largitionum habeat appellationem, ${ }^{3} \&$ tempus quo charta facta est, \& quæcunque in talibus scribuntur: \& ut protocollum non ${ }^{4}$ incidant, sed insertum relinquant: novimus enim multas falsitates ex talibus chartis ostensas \& prius, \& nunc: ideoque licet aliqua sit charta (nam \& hoc

1 Solent tabelliones contractus primo referre in schedam, deinde in mundum redigere: in mundum, id est, in chartam

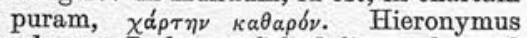
adversus Rufinum. Schedulis nondum ad purum digestis.

2 Protocollum quid esset, dixi in epigraphe hujus tituli.

3 Protocollis continetur nomen Comitis largitionum, \& tempus quo charta facta est, Jul. hic. num. 175.

4 Cur id jubeatur dixi in epigraphe . eod. is authorised by him for this purpose. If, however, this rule is trespassed and someone else is delegated, then the notary who has the authority defined by us above shall be liable to punishment, but the instruments, on account of their value to the contracting parties, shall not be declared void. For we know that through fear of the law notaries will obey these things which we have decreed and complete documents with extreme care.

\section{Chapter II.}

That notaries shall write the instruments in their protocol document and include the date and the name of the consul.

FurTher, we add to the present law, that notaries shall write their fair copies on no other sheet ${ }^{1}$ than the one (which carries the proto$\mathrm{col}^{2}$ ), and which states at the outset the name and title ${ }^{3}$ at the time of our Most Glorious Count of the Imperial Treasury, and the time when the document was executed and whatever it was customary to write there. And notaries must not ${ }^{4}$ cut off the protocol but leave it as originally inserted, for we know that many

1 Notaries generally draft contracts on paper, and then engross them clearly: "in mundum," that is, on a clean paper. Hieronymus against Rufinus. The drafts not yet reduced to [clean paper] fair copies.

${ }^{2}$ What the protocol is, I have exexpounded in my note to the inscription of this title.

3 The name of the Count of the Treasury (i.e. Consul) and the time when the document was drawn up must be contained in the protocol, Jul. hic. num. 175.

${ }^{4}$ Why that is forbidden, I have explained, eod. 
sancimus) habens protocollum non ita conscriptum, sed aliam quandam scripturam gerens, neque illam suscipiant, tanquam adulteram, \& ad talia non opportunam, sed in sola tali charta, qualem dudum diximus, documenta scribant. Hæc itaque quæ de qualidecreta sunt, \& de incisione eorum quæ vocantur protocolla, valere in hac felicissima solum ${ }^{1}$ civitate volumus, ubi plurima quidem contrahentium multitudo, multa quoque chartarum abundantia est, \& licet legali modo interesse negotiis, \& non dare occasionem quibusdam falsitatem committere, cui se obnoxios existere demonstrabunt, qui præter hæc aliquid agere præsumserint. tate talium chartarum à nobis

forgeries have been perpetrated in such charters, both formerly and at this time, to such an extent that some charters have protocols which do not pertain to them (and against this we decree punishment) but to other documents, thus invalidating them; hence the whole of the document must be written in one complete charter, as we have said previously, and not be exposed to such treatment. Therefore, whatever we have decreed concerning the nature of such documents, and concerning the cutting off of protocols, we desire to be of authority only ${ }^{\mathbf{1}}$ in this most fortunate State, where there is indeed a great number of persons entering into contracts and an abundance of blank papers, and it is an easy matter for the contracting parties to be present and conduct things legally and to afford no opportunity of any kind to any persons of committing forgery of which those will shew themselves guilty who venture to act contrary to this law.

\section{EPILOGUS.}

†. Quæ igitur placuerunt nobis, $\&$ per hanc sanctam declarata sunt legem, tua celsitudo operi effectuique tradere festinet. Dat. xIx. ${ }^{2}$ Kal. Septemb. Constantinop. post Belis. V.C. Cons, anno $11 .^{3}$

1 Non idem est in primo capite hujus Novellæ.

2 xvi. Scrimg. Julian.

I Id est, anno 537.

\section{EpILogue.}

Your Highness will hasten to put into practice these rules, which it has pleased us to enact by this law. Given at Constantinople, on the $19 \mathrm{th}^{2}$ of the Kalends of September, during the second year after the consulate of Belisarius. ${ }^{3}$

1 It is not the same at the beginning of this Novel.

2 Eod.

3 That is, in the year 537. 


\section{CUJACIUS: EXPOSITIO NOVEL. XLIV.}

\section{NovelLa XLIV.}

De instrumentis, \& vt protocolla instrumentis relinquantur.

TABELLIONES publici sunt contractuum scriptores, vt docui $l$. 15 . C. de decurio $l$. 14. §. his tabellionib. Cod. de sacrosanct. eccles. à

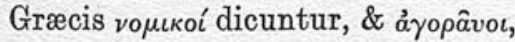
vt quæ ab eis conficiuntur in-

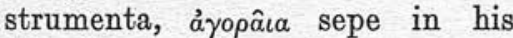
Nouellis, publica vel forensia, $l$. comparationes. $C$. de fid. instru. quanquam propriè publica ea tátùm sint, quæ insinuata sunt apud magistrum census, vel Duú uiros, vel defensores, ciuitatum. Solent autem tabelliones primum cótractus referre extra ordinem in schedam quæ sic dicitur ả $\pi \grave{o} \tau o \hat{v}$ $\sigma \chi \chi_{i} \zeta a v$, vel à scindendo, vt qui sine aspiratione scidá scribunt, sentiunt. Deinde redigunt eos in mundum, vel vt hæc Nouella loquitur, in chartam puram, \& hoc modo instrumenta complentur, absoluútur, expediunturque partibus l. cotractus. C. de fide instrument. $l$. vit. C. de cotrahen. empt. Hieronymus aduersus Rufinum. Schedulis nondum emendatis, nondum ad purum digestis. Exigitur à tabellionibus peritia iuris, Nou. 66 . j. \& Leonis Nouella quædam. Separantur tamé à iuris studiosis in $l$. moris. D. de poenis. Nec idem omnino iurisperiti \& iuris studiosi. nam \& tabelliones (vt dixi) \& aduocati; pragmatici, formularii, tabularii, iuris periti sunt, nec tamen iuris studiosi: hac

\section{Novel XLIV.}

Concerning Instruments, and that Protocols should go with Instruments.

TABELLIONES are public writers of contracts, as I have shewn (loc. cit.). By the Greeks they are called

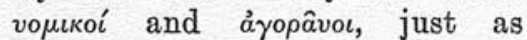
instruments completed by them are frequently designated in these Novels áyopâıa, public or forensic (loc. cit.), although properly only these are public which have been recorded with the Master of the Census, the Duumviri or the defensores civitatum. 1 Tabelliones are wont in the first place to take down contracts on a strip of paper, named "strip" from the Greek $\sigma \chi i\{a v$, or the Latin scindo, as those think who write scidá without the aspirate. They then reduce contracts to a fair copy or, as this Novel says, to clean paper, and so complete the instrument, expede it, and issue it to the parties (loc. cit.). Where drafts are not corrected [as in Hieronymus $v$. Rufinus] they are not yet in fair copy [cf. p. vii. n. 1]. Skill in the law is required of tabelliones (loc. cit.), but they are to be distinguished from law students. To be skilled in the law and to be a law student is by no means the same thing, for tabelliones (as I have said), advocati, pragmatici, formularii, tabularii are skilled in the law but are not students of law: the latter designation is applicable to the jurisconsult f.n. 2 .

1 Defensor civitatis. Vide supra, p. 29, 
enim appellatione iuris interpretes, consultiq; significantur. Constituitur autem hac Nou. vt. rogati tabelliones ipsimet adeant contrahentes, non discipulos mittant, vt ipsimet instrumenta forment, \& vt ne aliter ea discipuli ministrique absoluát edántque partibus, quam sciétibus præsentibusque tabellionibus. quod ideo constitutum est, ne interrogati à iudice tabelliones causentur ignorantiam rei gestæ. Cuilibet ergo contractui ipsi per se præesse \& interesse debent, \& gestorum omnium scientiam præstare, non vti hac in re opera discipulorum. Licebit tamen eis adiutorem, vel substitutú habere, \& per eum contractus formare absoluereque partib. \& per hunc quidem solum, nó per alium quemlibet. Probari hic debet apud acta magistri census. Hic magistratus erat in vrbe, quem

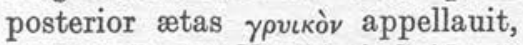
auctore Leone No. 44. \& Suida in Artemio, \& locum etiam ipsum quo acta \& insinuationes fiebant, quod \& Cedrino est $\tau \alpha \xi \epsilon \in \dot{\delta} \iota$ เov. In prouinciis partes eius sustinebant, defensores ciuitatum. Cur igitur magistro census hac Nouella non iunguntur defensores ciuitatú? quia hoc in vrbe tantùm permittit Iustinianus, vt tabellio habeat adiutorem \& quasi vicarium, propter ingentem numerú contrahentium. Pœna tabellionum qui per discipulum, exceptorem siue notarium, non per se instrumenta formant \& excipiunt, hæc est, vt excidant stationibus suis, \& officio tabellionum, \& vt statio transferatur in eum cuius opera vti maluerunt, si idoneus sit, whose office is to interpret the law. This Novel ordains that tabelliones, on request, must themselves meet with the contracting parties and not send their clerks, must themselves formulate their instruments and must, on no account, allow their clerks or assistants to draw up or issue instruments to parties except in their own presence and with their own knowledge. For that purpose this ordinance has been made to prevent the tabellio from pleading ignorance of the business carried through when questioned in Court. Accordingly, the tabellio must be present, superintend, and have knowledge of the business transacted, and not leave his assistants to attend to it. The tabellio is permitted, however, to have an assistant or substitute, and through him to draft contracts and issue them to parties, but through him alone and no other. $\mathrm{He}$, the substitute, ought to have approval registered in the records of the Master of the Census. The latter was a city magistrate, called in a

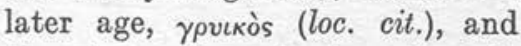
the place where deeds and notifications were recorded was styled $\tau \alpha \xi \epsilon \iota \delta \iota v$. In the provinces his place was taken by the defensor civitatis. ${ }^{1}$ Why, then, in this Novel are these two officials not named in conjunction? The reason is that Justinian permits the tabellio to have a substitute in the City only on account of the pressure of contractual business there. The penalty for a tabellio employing a clerk, exceptor or notarius, ${ }^{2}$ to do what is required of

1 Vide supra, p. 29, f.n. 2.

2 Vide supra, p. 12. 
vel in alium virum idoneum. Interdum alius est stationis dominus, alius tabellio: \& tunc ex facto tabellionis dominus stationis non læditur nam officio quidem \& statione tabellio remouetur, dominus tamen stationis proprietatem retinet, \& ex ea solemnes reditus atque obuentiones capit. $\mathrm{Ex}$ eo etiam tabellionis facto contrahentes non leduntur, id est, contractus non redditur inutilis. Notandum, initio huius Nouellæ differentiam constitui inter tabellionem \& tabularium, hic enim est sensus, Mulierem literarum ignará protulisseinstrumentum absolutum \& completum à tabellione, subscriptum à muliere tabularij manu, secundum Nouellá septuagesimam tertiam, ex qua quidam malè colligunt, duos tabularios exigi qui subscribant pro imperito literatû, vt Alciatus docuit 6. \& 8. $\pi \alpha . \rho \epsilon ́ \rho \gamma \omega \nu$. nam ex initio huius Nouellæ constat vnum sufficere, \& in Nouel. 73. legendum каi $\pi a ́ v \tau \omega s$, non $\delta v ́ o$ $\pi a ́ \nu \tau \omega s$. Igitur initio huius Nouellæ

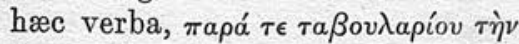

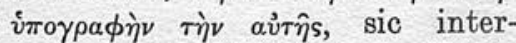
pretor, Per tabularium ipsius mulieris subscriptionem habens. Secundo capite huius Nouellæ constituitur ne tabelliones in mundum redigát contractum alia charta quàm ea quæ habeat protocollum : ex eo coargui falsum posse. Protocollum quid est? Alius maioré \& regiam chartam interpretatur, alius schedam negligentius scriptam, alius exemplar formularum, quo tabelliones vti solét. Omnes errant vehementer. Vt hodie chartæ habent notá aliquam, ex qua dignoscitur quis eam chartam præparauerit, ita habebant olim chartæ breuem adnotationem, quæ decla- him in person is deprivation of his rank and office of tabellio, and a transfer of these to his substitute, or to any other person if suitable for the position. Sometimes the dominus stationis and the tabellio are different persons: in this case the dominus stationis is not injured, for it is the tabellio who is removed from his office and rank, while the dominus retains the control of his office, his revenue, and his incomings. Nor are the contracting parties injured by the acts of the tabellio, i.e. the contract is not rendered worthless. It is to be noted that at the beginning of this Novel a distinction is made between the tabellio and the tabularius [his clerk]. The sense is that an illiterate woman put forward an instrument drawn up and completed by a tabellio, subscribed by the woman with the assistance of the clerk as the 73rd Novel relates. This Novel has been misread to imply that two clerks must subscribe for an illiterate person: so Alciatus (loc. cit.). But the beginning of the 73rd Novel makes it clear that one witness is sufficient. In that Novel кai $\pi \alpha ́ \nu \tau \omega s$ should

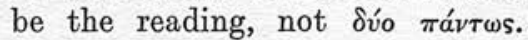
Thus I interpret the words at the beginning of this Novel, viz.

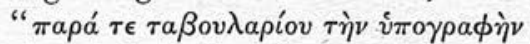

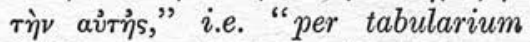
ipsius mulieris subscriptionem habens."

In the second head of this Novel it is laid down that tabelliones are forbidden to draft a contract on another leaf of paper than that on which is the protocol, for a forgery may thus be detected. What is a protocol? Some regard it as an important and ruling document, 
rabat quo Comite largitionum (sub eius cura erant chartarie) quo tempore, \& à quo præparatæ fuissent chartæ. ex eo coarguebatur sæpe falsitas: sicut Lutetie audiui accidisse, vt Senatus suspectum chirographum ex die in eo adscripto quo nondú eius notæ charta vlla erat in rerum natura, certissimo argumento quasi falsum improbaret. \& hac ratione Iustinianus nó vult ex chartis abscindi protocolla, \& hoc valere iubet in vrbe. Prius caput valet in vrbe \& in prouinciis. [ $\pi \epsilon \rho \grave{i} \sigma v \mu \beta o \lambda \alpha i \omega v]$ De hac voce sic Græci interpretes scribunt in hanc Nouellam. tò

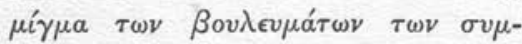

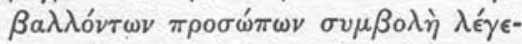

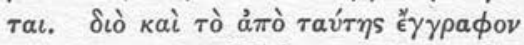

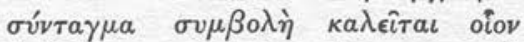

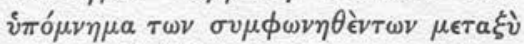

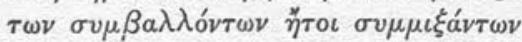

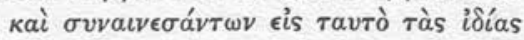

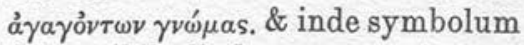
fidei, nihil aliud est, quam instru-

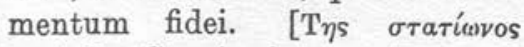
кvpíov] Græci interpretes, $\tau$ ov $\beta a \theta \mu o v$ кvрі́ov. others as a carelessly written draft, others as a style which tabelliones were wont to use. All are entirely wrong. As to-day paper has a mark from which it is known who made that paper, so, of old, paper had a brief note which stated under which comes largitionum (under whose charge were the paper factories), when and by whom the paper was prepared. From that forgeries were often detected: so I have heard that it happened in Paris that the Senate denounced by indisputable argument as false a suspected chirograph because no paper of that mark could have existed on the date when the deed was stated to have been written ( $c f$. p. i. n. 1), and for this reason Justinian did not permit the protocol to be separated from the document, and ordered this to be the rule in the City. The former head is to run both in the City and in the Provinces [ $\left.\pi \epsilon \rho i \quad \sigma v \mu \beta o \lambda \alpha i{ }^{\prime} \omega \nu\right]$. Regarding this word, the Greek commentators on this Novel write as follows: "The compound of the designs of the contracting parties is called a contract, $\sigma v \mu \beta o \lambda \dot{\eta}$, wherefore also the registered document is styled a contract as a record of the agreement between the covenanting parties, that is those who have joined together and consented, after bringing their individual intentions to coincide." Hence a 'symbol' of faith is simply an instrument of faith.

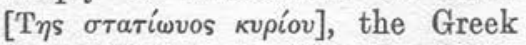
interpretation is "Lord of the $\beta a \theta$ нós." 


\section{COD. JUSTINIANI}

Novelua Constit. LXXIII

Idem Imp. Ioanni gloriosiss. Orientalium prctoriorum prefecto, iterum exconsuli \& patricio.

\section{PRAFATIO.}

Novimus nostras leges ${ }^{1}$ quæ volunt ex collatione literarum fidem dari documentis, \& quia quidam imperatorum super excrescente jam malitia eorum qui adulterantur documenta, hæc talia prohibuerunt: illud studium falsatoribus esse credentes, ut ad imitationem literarum semetipsos maxime exercerent, eo quod nihil est aliud falsitas, ${ }^{2}$ nisi veritatis imitatio. Quoniam igitur in his temporibus innumeras invenimus falsitates in judiciis multis, quorum fuimus auditores, \& quoddam inopinabile ex Armenia nobis exortum est. Oblato namque commutationis ${ }^{3}$ documento, \& literis dissimilibus judicatis, quoniam postea inventi sunt ii qui de documento testati sunt, subscriptionem subdentes, \& eam recognoscentes, fidem suscepit documentum, \& quoddam hinc inopinabile occurrit, eo quod litteræ quidem sine fide visæ sunt, licet examinata responsa verorum testium cum veritate concordaverunt: \& hoc per fidem testium, quæ videtur quodammodo esse cauta. videmus tamen naturam

\footnotetext{
1 Nov. 49. c. 2.

2 Adde 1. Harmen. 6. §. 10. l. 23. ff. ad. l. Corn. de falsis.

3 Permutationis.
}

\section{Seventy-third Novel (New Constitution)}

The same Emperor [Justinian] to John, Most Eminent Pratorian Prefect of the East, twice Consul and Patrician.

\section{PREFACE.}

WE are aware of laws ${ }^{1}$ instituted by us which provide that instruments may be proved genuine by a comparison of handwriting, and of the prohibition of forgery, by certain Emperors, which had become a serious and increasing evil, in the certain belief that some persons made it their special study to excel in the imitation of the handwriting of others, for forgery ${ }^{2}$ is nothing else than an imitation of the truth. In these times we have found innumerable forgeries in the lawsuits which have come before us, and also a strange case arisen in Armenia has come to our notice. In this case an instrument of exchange ${ }^{3}$ was produced, the handwriting of which was decided to be forged, but afterwards, when the witnesses of the instrument were found, they verified their signatures and the document was held to be genuine. The remarkable feature of this case was that the instrument on examination was deemed unworthy of credit, but the answers of the actual witnesses declared for its

\footnotetext{
1 Eod.

2 Eod.

3 "Permutationis" is generally used in other versions of the Novels.
} 
ejus crebro egentem rei examinatione, quando literarum dissimilitudinem sæpe quidem tempus ${ }^{1}$ facit, non ${ }^{2}$ enim ita quis scribit juvenis \& robustus, ac senex \& forte tremens, sæpe autem \& languor hoc facit: \& quidem hoc dicimus, quando calami \& atramenti immutatio, similitudinis per omnia aufert puritatem, \& nec invenimus de reliquo dicere quanta natura ${ }^{3}$ generans innovat, \& legislatoribus nobis præbet causas.

§. 1. Quia igitur imperium propterea Deus de ${ }^{4}$ cœlo constituit, ut $^{5}$ difficilibus imponat quæ apud eum sunt bona, \& leges aptet secundum naturæ varietatem: propterea existimavimus oportere \& hanc scribere sanctionem, \& dare in commune subjectis, quos nobis Deus \& prius tradidit, \& paulatim semper adjiciet. Etenim quiddam VII * de deposito in scripto dubitatum $\&$ ad contentionem deductum invenimus, \& oportet etiam omnino horum prospicere: itaque illico nobis est à deposito inchoandum.

1 Tempus efficit, ut unius ejusdemque hominis diversæ quodammodo videantur scripturæ.

${ }^{2}$ Quæ res efficiant, ut unius ejusdemque hominis scriptura, diversorum videatur hominum.

3 Natura generans multa innovat, Nov. 74. c. 1.

- Magistratus à Deo.

$\checkmark$ Scopus magistratuum.

* See Appendix E, p. li. authenticity thus established by the faith of the witnesses to some extent held to be reliable. We, however, recognise from the nature of this case that examination into the comparison of handwriting is frequently necessary where age ${ }^{1}$ causes dissimilarity in the handwriting, for ${ }^{2}$ no one would write alike when young, in his prime, or in old age when tremulous and feeble: and indeed we can say that a change of pen and ink removes entirely the clear resemblance of identity of handwriting. Nor can we tell how many novel situations the world of Nature ${ }^{3}$ may produce and so make necessary new legislation by us.

$\S$ 1. Therefore, as God from Heaven has ordained empire ${ }^{4}$ for the special purpose of effecting ${ }^{5}$ in difficulties what is good in his sight and of adjusting its laws to the diversity of Nature, so we have deemed fit that the present law be put into writing and delivered to our subjects over whom God has placed us, as well as to those in course of subjection to our rule. Also we have found doubts and disputes arising out of deposits constituted in written instruments, and it is necessary for us to give attention to them. Accordingly we will begin with the contract of deposit.

1 The passage of time results in the handwriting of a person varying with his age.

2 These reasons explain how the writings of one man may seem to be those of another man.

3 Fertile Nature introduces many innovations, Nov. 74, c. 1 .

4 Magistracy is from God.

5 The extent of the magistrate's jurisdiction. 
CAP. I. ${ }^{1}$

De instrumentorum cautela \& fide: \& primum de deposito, quemadmodum caute dari potest.

$\mathrm{SI}^{2}$ quis igitur vult caute deponere, ${ }^{3}$ non soli ${ }^{4}$ credat accipientis scripturæ, (hoc quod etiam in judicio quæsitum est, quia enim VIII * non ${ }^{5}$ professus est is qui scripsisse dicebatur, suam esse scripturam: magnum res habuit tumultum \& scribere alia coactus $^{6}$ est, quæ visa sunt veluti similia quidem, non tamen per omnia similia, \& quantum ad illam scripturam sine termino causa permansit) sed is qui depositum dat, advocet ${ }^{7}$ etiam testes, ut possibile est ${ }^{8}$ honestos \& fide dignos, \& non minus tribus ${ }^{9}$ : ut non in sola scriptura $\&$ ejus examinatione pendamus: sed sit judicantibus etiam testium solatium. Etenim tales testificationes suscipimus, quas præsentes testes dicant: quia his prcesentibus subscripsit qui documentum fecit, \& hunc noverunt. Nam si invenerimus $\&$ tales quosdam testes non minus

1 Jul. num. 233.

2 Hinc sumpta est Authentica, Si quis vult C. qui potior, adde $22 \mathrm{Ecl}$. 4. c. 1 . d 3. Harm. 2.

3 Id est, alicui depositum tradere, vel rem custodiendam committere.

4 Cur ita? vid. j. eod.

5 Id est, quia noluit adgnoscere suam esse scripturam: quia suam denegavit.

- Negans cautionem aliquam à se scriptam, scribere cogitur, ut ex nova ejus scriptura veritas antiquioris arguatur.

7 Cautio deponenti observanda.

8 Quid si nolit depositum evulgare? vid. c. 2. j. eod.

9 Vid. Jul.c. 66. n. 233. hoc necessitatis causa non datur, sed majoris probationis gratia, $v$. nam si j. eod.

* See Appendix E, p. li.
Chapter I. 1

Concerning the security and reliability of written instruments, and first concerning deposit and how security can be achieved.

$\mathrm{IF}^{2}{ }^{2}$ therefore, one should wish to place something safely on deposit, ${ }^{3}$ let him not put his faith solely ${ }^{4}$ in the written contract of him who receives the deposit (which is also required by law, since, if anyone denies ${ }^{5}$ that the instrument has been written by him, the matter becomes complicated and that person will be compelled ${ }^{6}$ to produce another writing of his, and if it is seen to resemble the writing in the instrument only partially, then the case regarding the matter remains undecided with regard to the writing). Let him who places anything on deposit call $^{7}$ witnesses ${ }^{8}$ as honourable and credible as he may be able to find and not less than three, ${ }^{9}$ so that reliance is not solely on the handwriting and its examination, but that the judges may have the assistance of the witnesses. For we accept such

1 Jul. No. 233.

2 Eod.

3 That is, to hand over a deposit to someone, or to entrust something for safe-keeping.

4 Why so? vid. j. eod.

5 That is, since he is unwilling to avow his own writing: since he has denied his writing.

${ }_{6}$ Denying any obligation to have been written by him, he will be made to write so that from this new writing the truth of the former writing may be proved.

7 The security the depositor should observe.

8 But if he does not wish to divulge the deposit? vid. c. $2, \mathrm{j}$. eod.

${ }_{9}$ Vid. Jul. c. 66, n. 233. This is not designed for the reason of necessity, but for the sake of greater proof, $v$. nam si $\mathrm{j}$. eod. 
quam tres dignos fide existentes: neque ${ }^{1}$ talem interdicimus fidem: neque enim ut abbreviemus probationes, ponimus legem: sed ut esse eas \& caute esse faciamus.

\section{CAP. II.}

Quemadmodum sine tabellione instrumentum mutui vel depositi caute fieri potest.

SED \& si quis aut mutui instrumentum, aut alterius cujuspiam faciat, \& noluerit hoc in publico confiteri, quod \& in deposito definivimus, non ex ipso videatur credibile quod scribitur super mutuo documentum, nisi etiam testium habeat præsentiam fide dignorum non minus trium ${ }^{2}$ : ut sive veniant, \& propriis subscriptionibus attestentur: $\operatorname{sive}^{3}$ alii quidam testificentur, quia prasentibus eis confectum est documentum: fidem causa ex utroque percipiat, etiam literarum examinatione penitus non repulsa, sed sola non sufficiente, augmento autem testium confirmanda.

1 Depositi probari non potest paucioribus testibus quam tribus: alia tamen probatur ratione quam testibus c. 4. in fin. j. eod.

2 i. 20.C. de fid. instrum. Imo quinque: 1. Harm. 6. §. 3 .

${ }^{3}$ Nihil interest, utrum subscripserint testes, an præsentibus ipsis instrumentum depositi fuerit compositum, Jul. Const. 60. n. 234. testimony where the witnesses say that he who wrote the instrument signed it in their presence and that they identify him. If we find that there are not fewer than three such credible witnesses, we ${ }^{1}$ do not repel their testimony for we are not laying down this law to shorten proofs but to give reliability to them.

\section{Chapter II.}

How, without a notary, instruments of loan or deposit may be safely drawn up.

IF anyone wishes to effect an instrument of loan or of some other similar contract, and does not wish it publicly made, this instrument, as we have just laid down in respect of a deposit, shall not be considered credible of itself unless there were present at least three ${ }^{2}$ reliable witnesses so that they may come and attest the validity of the instrument by their own signatures, or ${ }^{3}$ testify that it was executed in their presence, in either of which cases the instrument will receive credence, and while examination of the handwriting is not to be wholly discarded, it is not to be held sufficient to found upon alone, but must be confirmed by witnesses.

1 It is not possible to prove the contract of deposit with less than three witnesses, c. 4 , in fin. j. eod.

2 1. 20, C. de fid. instrum: On the contrary, five. 1 Harm. $6, \S 3$.

${ }^{3}$ It is immaterial whether the witnesses have subscribed or whether the instrument of deposit has been completed in their presence. Jul. Const. 60, n. 234. 
CAP. III.

\section{$S i^{1}$ literarum fides à voce testium discrepet.}

Si vero tale aliquid contigerit quale in Armenia factum est, ut aliud quidem faciat collatio literarum, aliud vero testimonia: tunc nos quidem existimavimus ea quæ viva $^{2}$ dicuntur voce, \& cum jurejurando: hæc digniora ${ }^{3}$ fide quam scripturam ipsam secundum se subsistere. Veruntamen sit hoc judicantis prudentiæ ${ }^{4}$ simul atque religionis, ut veracibus potius pro talibus credat: \& nos quidem secundum hunc modum existimavimus oportere probari fidelia documenta.

\section{CAP. IV.}

\section{De instrumentis incaute 5 compositis.}

Si tamen quisquam aut deponens, aut mutuans, aut aliter contrahens, contentus sit scriptura sola ejus cum quo contrahit: in ipso erit ut sciat quia in illius fide totum ipse suspendit, ${ }^{6}$ \& quidem quantum ex scriptura non sufficiens videbitur fides, nisi ? secundum no-

1 1. Harm. 6. \$. 4.

2 Deest hæc particula apud Scrimgerum.

3 Viva vox cum jurejurando scripturam superat, tesmoin passe lettre : dixi ad $l$. 15. C. de fide instrum. 1. Harmenop.

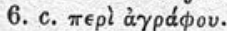

4 Vid. l. 3. C. de testib.

- Id est, nuda suscipientis scriptura.

- Ideoque incaute facturus est. Jul. hic, num. 236.

7 Interpretatio est corrupta: sensus hic est: Deponentem, accepta depositarii nuda scriptura, pendere pene ex sola
Chapter III.

\section{Where ${ }^{1}$ the written instrument differs from the oral evidence of witnesses.}

IF indeed a similar case to that which happened in Armenia should occur, that comparison of the handwriting leads to one conclusion and the evidence of witnesses to another, we have then thought that the evidence of the living ${ }^{2}$ voice, taken on oath, is more credible ${ }^{3}$ than that of the writing taken by itself. Nevertheless it shall rest with the prudence ${ }^{4}$ and conscientiousness of the judge to give credence to what appears to be better entitled to be the truth, and we have decided that documents ought to be proved this way as to their genuineness.

\section{Chapter IV.}

\section{Concerning instruments drawn up without security. ${ }^{5}$}

WHERE, however, anyone whoplaces something on deposit or gives a loan or contracts in any other way, is satisfied with the writing only of him with whom he contracts, he must recognise that the instrument will not be worthy of any credence ${ }^{6}$ unless, ${ }^{7}$ in accordance with our law,

1 Eod.

2 This clause is lacking in Scrimgeour.

3 Oral testimony on oath prevails over writing, eod.

4 Eod.

5 That is, the mere written acknowledgment of the receiving person.

6 And for that reason it has been made without security. Jul. hic num. 236.

2 The translation is corrupt: the meaning is: the depositor, having accepted the bare writing of the depositary, relies 
stram legem adjiciatur documento credulitas, aut præsentia testium coram quibus contractus est factus: aut forsitan novissimum ${ }^{1}$ ejus rei refugium invenerit: dicimus autem quod ex jurejurando est, nam non infirmamus, quod factum est: nam falsitates \& imitationes metuentes, \& nudis eis existentibus non credentes, hujusmodi subtilitatem causæ addimus: non ${ }^{2}$ ut credentes privemus fide sua circa amicos, sed ut quantum possibile est, \& perfidiam \& negationem multis reconvincamus modis.

CAP. V.

\section{Quomodo tabelliones caute debeant instrumenta componere.}

SED \& si instrumenta publice confecta sint: licet tabellionum habeant supplementum, ${ }^{3}$ adjiciatur \& eis antequam ${ }^{4}$ compleantur (sicut dictum est) testium ex scripto præsentia.

fide depositarii, cum is possit facile scripturam negare: ejusque scripturam esse, difficilimum sit (propter varietatem quæ in scripturis accidit in pr. s. eod.) probare, superesse tamen vel hoc divinum remedium, ut jusjurandum depositario deferatur.

1 l. 1. ff. de jurej. l. 25. §. 3. ff. de prob. l. 3. C. de reb. credit.

${ }^{2}$ c. 1. in fin. s. eod.

3 ח $\lambda \hat{n} \rho \omega \sigma \iota \nu$ impletionem.

4 Instrumentum non dicitur completum, priusquam subscriptum à testibus sit: adeo ut sola tabellionis subscriptio non sufficiat, nec credatur scripturæ tabellionis sine testibus. In judiciis tamen acta sine testibus valent: l. 31. C. de donation, ideoque Rolandus à Valle, vide cons. 38, num. 5. 6. refert ad instrumenti necessariam subscriptionem, ut \& sequentia, tabellionem rogari à contrahentibus: locum contractus inseri, n. 4. \& 7. adde Jul. hic n. 228. its genuineness is confirmed by the presence of the witnesses before whom it was executed, or by that last resort of law proceedings, ${ }^{1}$ namely, by the sanction of an oath. We do not, however, declare such an instrument to be void, for we have added this precision to the law because we fear forgery and imitations and do not trust to mere written instruments, not ${ }^{2}$ with a view to depriving persons of the trust they put in those with whom they contract but, so far as possible, to enable perfidy and falsehood in their many forms to be avoided.

\section{Chapter V.}

\section{How notaries should complete their instruments securely.}

BuT in the case of public instruments, even if they have been completed ${ }^{3}$ by a notary, it must be stated, prior to completion ${ }^{4}$ (as has already been said), that they were written in the presence of witnesses.

almost entirely on the faith of the de. positary, since the latter is easily able to deny the writing (on account of the variety of handwritings), but yet to that is added the divine remedy that the question may be referred to the oath of the depositary.

1 Eod.

2 Eod.

$3 \Pi \lambda \hat{h} \rho \omega \sigma \iota \nu=$ fulfilment.

4 An instrument is not considered complete until it has been signed by the witnesses: so that the subscription by the notary is not enough, nor will his writing be accepted unless there are witnesses. In Court, however, decreets are valid without witnesses: $l$. $3, C$. de donation, and in that connection Rolandus à Valle, vide cons. 38, num. 5, 6, refers to the necessary subscription of the instrument and what follows, namely the notary is summoned by the contracting parties, and the place where the contract is drawn must be inserted, n. 4 \& 7, adde Jul. hic n. 228. 
CAP. VI.

De comparatione notarum.

Oportet autem judicantes, \& si qua signa ${ }^{1}$ invenerint adscripta chartis, etiam hæc requirere, \& legere niti. Plurima namque novimus \& ex aliis apparuisse, non facile fidem ex literarum aliarum collatione recipere, propter dudum dictas à nobis causas.

\section{CAP. VII.}

De comparatione literarum.

Si vero moriantur omnes testes, aut forsan absint, aut aliter non facile sit fidem ex testium subscriptionibus invenire, necque tabellio superest qui complevit: (si quidem publice sit confectum) quatenus testimonium perhibeat pro se, aut non est in civitate: sed necesse est omnino collationem literarum suppletiones eorum qui subscripserint, assumere: tunc $^{2}$ competens est properare quidem ad comparationes, (neque enim eas modis omnibus interdicimus) per omnem autem subtilitatem procedere, \& omnino, (si putaverit eis judex oportere credi,) etiam jusjurandum ${ }^{3}$ injicere proferenti: Quia ${ }^{4}$ nihil maligni conscius in eo quod à se profertur, nec quandam

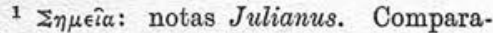
tione non tantum literarum, sed etiam notarum falsitas arguitur. Jul. hic num. 238. Notæ non sunt literæ. $l$. 6. in fin. ff. de bon. possess. sed literarum compendia.

2 Testibus \& Tabellione absentibus aut mortuis, is qui jus ex testamento prætendit, comparationem ejus cum aliis scripturis notarii fieri, potest petere.

3 Postulans comparationem instrumentorum fieri, jurare debet de calumnia.

- Jurisjurandi formulam observa.
Chapter VI.

Concerning comparison of notes.

IF judges find any notes ${ }^{1}$ appended to documents, they must examine them and attempt to read them. For we know that there are many documents which, for the reasons stated by us, are not easy to be proved by comparison with other documents.

\section{Chapter VII.}

\section{Concerning the comparison of handwriting.}

But where all the witnesses are dead or absent, or it is not easy to confirm the genuineness of their signatures, or if the notary who drew up the document is dead (if it was executed in public), or cannot give evidence on his own behalf, or is not in the city, it will be necessary to compare the handwriting of those who have signed the document, and that ${ }^{2}$ should be done with the utmost dispatch (for we by no means prohibit such comparisons) and also with the greatest care, and (if the judge thinks it necessary) he must administer an oath ${ }^{3}$ to the plaintiff as follows: "that" he has not proceeded from grounds of malice nor has acted fraudulently in the comparison of

1 ¿ $\eta \mu \epsilon \hat{\imath} \alpha=$ notes; Julian. Falsehood may be proved, not only by a com. parison of handwriting, but also by that of notes. Jul. hic num. 238. Notes are not formal documents, $l$. 6, in fin. ff. de bon. possess., but an abridgement of them.

2 Where the witnesses and notary are absent or dead, he who alleges a right under a will may demand a comparison of that document with other instruments written by the same notary.

3 Assuming a comparison of instru. ments is to be made, there ought to be the oath de calumnia.

4 Note the form of the oath. 
artem circa collationem fieri praparans, sic utitur eo, quatenus neque perimatur quicquam omnino, \& per omnia munitio in rebus fiat.

$\S .1$. In his vero quæ conficiuntur publice $^{1}$ documentis, si tabellio venerit, \& testimonium perhibuerit cum jurejurando, si quidem non per se scripserit, sed per $^{2}$ alium ministrantem sibi, \& ille, ${ }^{3}$ si vivit, si quidem possibile omnino est eum venire, \& nulla causa prohibet ejus adventum, ægritudo forte valida, aut quælibet aliarum necessitatum quæ hominibus accidunt. Quod si etiam adnumeratorem ${ }^{4}$ habuerit instrumentum, \& ipse ${ }^{5}$ adveniat: ut tres sint testificantes, \& non unus. Si vero necque adnumerator ${ }^{6}$ assumptus est, \& instrumentum ipse tabellio totum per se conscripsit, atque supplevit, aut si etiam qui hoc conscripsit,? non est, aut aliter ipse venire non valet: tamen cum jurejurando propriæ $^{8}$ completioni attestetur, ${ }^{9}$ ut comparationi non fiat locus, sint etiam sic credibilia documenta, testimonium enim \& ex voce

$1 \mathrm{E} \pi$ ' aropais. Scrim.id est, in forensibus instrumentis.

2 Notarius per substitutum potest subscribere.

3 Minister ac substitutus notarii, amanuensis.

4 A $: \theta \mu \eta \tau \hat{\eta} \nu$ argentarium, numeratorem pecuniæ. Fingamus contineri in instrumento pecuniam numeratam fuisse per Titium, vide Julianum hic. n. 239.

5 Puta tabellio, ejus amanuensis \& argentarius pro tribus testibus habentur.

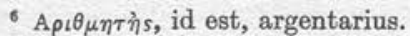

7 Amanuensis scil.

8 Confecto à se operi.

2 Solus tabellio, scil. $\mu \delta ́ v o s, \tau \alpha \beta \in \lambda \lambda i \omega \nu$, testimonium ipsius probabile sit, Julianus

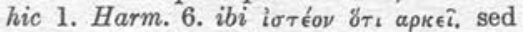
tamen Cujacius hic ex hujus Novellæ sententia requirit duorum testium præsentiam aut subscriptionem. alias, forense handwritings and that he will so conduct himself that nothing may remain concealed and that, throughout, rectitude will be established in all things.

$\S 1$. In the case of those instruments made publicly, ${ }^{1}$ where a notary is present, he shall give his testimony on oath, but if the instrument was not written by himself but ${ }^{2}$ by someone in his service, the latter shall also come forward if he ${ }^{3}$ is alive and it is possible for him to do so, and no reason shall excuse his appearance unless, for example, a severe illness or some other similar necessity to which men are liable. If a banker ${ }^{4}$ is concerned with such an instrument he ${ }^{5}$ shall be present, so that there may be three witnesses to testify and not only one. But if no banker ${ }^{6}$ is concerned and the notary himself wrote it all and completed the instrument, or if he who wrote the instrument ${ }^{?}$ is absent or otherwise not able to come forward himself, the notary shall testify on oath ${ }^{8}$ to his own completion of the instrument ${ }^{9}$ so

1 In the market place. Scrimgeour says: documents executed in the forum.

2 The notary is able to subscribe by a substitute.

3 The servant or substitute of the notary, the writer.

${ }_{4}^{4}$ A $\iota \theta \mu \eta \tau \eta \nu$ : banker or counter of money. We represent the money contained in the instrument to have been counted per Titium, see Jul. hic. n. 239.

5 I consider the notary, his clerk and the banker may be regarded as the requisite three witnesses.

${ }_{6}^{6} \mathrm{~A} \iota \theta \mu \eta \tau \eta \dot{s}$, that is, the banker.

7 Doubtless the clerk.

8 That the work has been completed by him.

? The notary alone (doubtless, $\mu$ bos $\tau \alpha \beta \in \lambda \lambda(\omega \nu):$ his testimony may be credible,

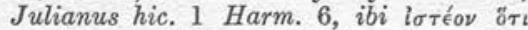
аркєî, nevertheless, Cujacius, from the reading of this Novel, requires the presence or subscription of two witnesses, 
complentis factum, \& jusjurandum habens adjectum, præbuit quoddam causæ monimentum. ${ }^{1}$

§. 2. Quod si tabellio defunctus est, \& testimonium perhibeatur suppletioni ex alia collatione: si quidem etiam sic habeat eum, qui conscripsit instrumentum, viventem, \& adnumeratorem: adveniant ${ }^{2} \&$ illi, si quidem præsentes sunt, \& habeat ex collatione adimpletionum \& ex testibus causa fidem. Si vero nullus horum sit, tunc fiat quidem completionum collatio: non autem sola hæc ad hoc sufficiat, sed \& aliorum subscribentium forte aut contrahentium scripturæ examinentur: ut ex plurimis comparationibus, tam completionis quam subscribentium forte aut etiam contrahentium, una quædam colligatur undique \& efficiatur fides.

instrumentum fidem non habere ex solius notarii fide: aliud esse in instrumento actus insinuato apud magistrum census, vel magistratus municipales, vel defensores plebis. vide $l$. publicat $l$. 2. C. de testam.

$1 \mathrm{Al}$. momentum.

2 Mortui tabellionis instrumentum falsi per duos testes potest argui: eo tamen ordine: Primo per tabellionis substitutum \& eum qui creditoris nomine pecuniam numeravit: his demortuis, per testes qui instrumento subscripserunt: his rursus mortuis, eorum scripturæ cum aliis eorundem scripturis comparantur. that there will be no necessity for a comparison of handwriting. In this way the documents will be credible, for to the spoken evidence of him who completed the instrument his oath is superimposed, the latter making the added weight which turns the scale in the matter. ${ }^{1}$

$\S 2$. But if the notary is dead, the testimony shall be borne to his completion of the instrument by a comparison of his writing in the completion of other deeds. If the person who drafted the document and the banker who is concerned therewith are alive, they must appear ${ }^{2}$ if they are not absent, and the instrument will be established by a comparison of the completiones [i.e. docquets of the notary: see p. 38 , supra] and by the statements of witnesses. If, however, neither of these persons are available, then a comparison of handwriting should certainly be made, but for the purpose in hand this will not be sufficient of itself as an examination should also be made of other writings of those who subscribed and of the parties to the contract, so that by these comparisons, as well as of the notarial hand-writings, the good faith of the document may be perfectly estab-

otherwise the instrument would have no credibility in law from the faith of the notary alone; the matter is different where the instrument has been registered with the Master of the Census or the city magistrate, or the public advocate: vide eod.

1 Otherwise "momentum."

2 I have shewn that the instrument of a deceased notary may be proved false by two witnesses, in order thus: first, through the substitute of the notary and him who in name of the creditor has counted the money; when these are dead through the witnesses who have subscribed the instrument; again when they are dead from a comparison of the writing with their other writings. 
§. 3. Si vero nihil aliud inveniatur præter collationem instrumentorum: quod hactenus valuit, fiat: ut qui profert ad ${ }^{1}$ collationes documentum juret solemniter. ${ }^{2}$ Ut autem aliquod omnino causa sumat augmentum ad majorem negotii fidem: \& ipse qui ${ }^{3}$ hoc petit fieri, juret: quia non aliam idoneam habens fidem, ad collationem instrumentorum venit: nec quicquam circa eam egit aut machinatus est quod possit forte veritatem abscondere: de quibus ${ }^{4}$ licebit sese liberare contrahentes, si consenserint utrique ad hoc venire, ut insinuent 5 instrumenta: \& profiteantur ea sub gestis monumentorum ipsi contrahentes, quatenus priventur nequitia \& corruptione \& falsitatibus: \& quæcunque alia mala corrigentes, præsentem promulgamus legem: iis quæ dudum à nobis in collationibus literarum factarum, per scripturam propriæ manus sancita sunt, in sua virtute manentibus: proculdubio \& in iis qui literas ${ }^{6}$ nesciunt, quæ olim valent in judiciis, suam habentibus firmitatem: quoniam quidem ex judiciali forma acceperunt examinationem hæc talia competentem.

1 Id est, ut qui instrumentum petit proferri, juret solemniter.

Quid jurabit? se nulla malitia usum. vide Jul. hic num. 239.

3 Id est, qui petit comparationem literarum fieri.

4 Id est, qui contrahunt, scrupulo \& onere eorum quæ dicta sunt, possunt facile se liberare, si consenserint, \&c.

5 Instrumentum insinuatum magnæ authoritatis est: ei namque creditur omnimodo.

- Vid. Jul. hic num. 240. lished by combining into one the evidence led from all quarters.

$\S 3$. Should it be that no other course is open but that of collating 1 the instruments, then the procedure should follow the established usage that he who produces a document for comparison should take the customary oath ${ }^{2}$ and, in order that the greatest confidence may be supplemented, he ${ }^{3}$ who has asked for a comparison should take an additional oath that, "because he is unable to produce any other proof, he has had to have recourse to a comparison of instruments and that, in taking this course, he did not do so through malice and was guilty of no device whereby it was likely the truth might be concealed." Concerning this procedure, those who contract can free themselves, if they have agreed to have the instruments duly recorded ${ }^{5}$ and make them public by registering them in the registry of records, thus preventing allegation of bad faith, corruption or falsehood: for we have promulgated this law for the suppression of anything fraudulent. What we have already laid down as to handwriting in private instruments shall remain in force and, in the case of doubt or where the parties are illiterate, ${ }^{6}$ the former practice

1 That is, that he who seeks to establish the instrument is solemnly sworn.

2 What will he swear? That he is actuated by no malice. Vide Jul. hic num. 239.

3 That is, he who demands a comparison of handwriting.

4 That is, those who have contracted can free themselves from the care and burden of those things which are said, if they have agreed, etc.

${ }_{5} \mathrm{~A}$ recorded instrument has the highest authority: for it must be believed in every respect.

6 Eod. 
of our Courts shall be followed, since these matters receive suitable attention under judicial sanction.

CAP. VIII.

\section{Imperiti literarum quomodo caute contrahant.}

Oportet vero in iis qui literas 1 nesciunt, \& testes \& omnino ${ }^{2}$ tabularios $^{3}$ adhiberi, in quibus locis sunt tabularii, maxime autem testes $^{4}$ non ignotos ${ }^{5}$ contrahentibus: ut quidam scribant pro illiterato, aut paucas literas sciente: alii vero attestentur, quia etiam prosentibus eis hac gesta sunt, \& scierunt eum : \& ita talium instrumentorum suscipiatur fides, manifestum existens, quia non minus quam quinque ${ }^{6}$ testes in his talibus adhibendi sunt, inter quos erit \& qui scribit pro ${ }^{7}$ contrahente, aut totum [aut post ea quæ] post

1 Hoc est, qui imperiti scribendi. Nov. 44. c. 1 .

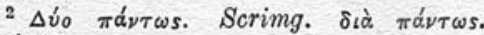
Cujac.

${ }^{3}$ Jul. ibid. num. 241.

4 Quinquo. j. eod.

5 Testis instrumentarius potest reprobaxi, si ignotus sit contrahentibus.

6 Tabellio scil. tabularius ejus, \& tres testes.

7 Sensus est obscurus, quem ita ex Juliano hic. n. 241. collige. Pro imperito literarum tertius potest subscribere. Nemo tamen scribendi sic imperitus est, quin inducta illi manu ab uno testium, sanctum crucem facere possit, \& paucas literas scribere. Hoc ita peracto, quinque testes subscribere debent, quod præsentibus eis imperitum scribendi cognoscentibus, res omnes ita processerint, Jul. dicto loco. vide quæ scripsi ad Novell. Leonis 72. \& ita literarum imperiti debent instrumenta componere. Sic in accusatione pro literarum imperito scribi potest, $l$. 3. §. 2 . ff. de accus.

\section{Chapter VIII.}

In what way those unskilled in letters can make contracts in safety.

IT is necessary, in the case of those who are ignorant of letters, ${ }^{1}$ for witnesses and especially ${ }^{2}$ for notaries, ${ }^{3}$ to be present in those places where notaries are available, and it is specially essential that the witnesses ${ }^{4}$ should be known ${ }^{5}$ to the parties to the contract and that someone should write for those who are illiterate or have little knowledge of letters, or testify to the truth that the documents were drawn up in their presence and that they knew the contracting parties, and thus the legality of such instruments may be established, for there must be not less than five ${ }^{6}$ witnesses present, including the person who drew up the instrument entirely or who wrote ${ }^{7}$ for those

1 This is, those who are unskilled in writing.

2 Eod.

3 Eod.

4 Eod.

5 The witness to an instrument can reject it if he does not know the contracting parties.

6 The notary and, doubtless, his clerk, and three witnesses.

7 The meaning is obscure, see Jul. hic. n. 241. A third party can subscribe on behalf of an illiterate person. Yet no one is so unskilled in writing but that, with the aid of one of the witnesses guiding his hand, he can make a cross and write a few letters. This having been done, the whole procedure now is that five witnesses must subscribe in the presence of a contracting party known to be illiterate. See my account in Leo's 72nd Novel as to the drawing up of instruments of illiterate persons. Also in the case of an indictment writing can be done on behalf of an illiterate person, $l$. $3, \S 2 \mathrm{ff}$. de accus. 
paucas ${ }^{1}$ literas illius posita sunt: quatenus nihil omittant de summa subtilitate. Et hæc dicimus super instrumentis $\mathrm{ex}^{2}$ scripto confectis: nam si quis facere quemlibet contractum ex ${ }^{3}$ non scripto voluerit, hoc manifestum est, quia aut per testes, aut per jusjurandum * fidem percipiet: actore quidem testes deducente, pulsato autem jurante aut referente, sicuti judex negotium disposuerit. Ut ${ }^{5}$ autem nihil sit neque horum inemendatum: illud quoque adjicere legi bonum est, ut si usque $\operatorname{ad}^{6}$ unam auri ${ }^{7}$ libram fuerit contractus: hujusmodi observationem in hoc minime custodiri: sed secundum hoc quod tunc actum est, causam fieri, ut non de rebus $^{8}$ exiguis maximas attritiones homines sustineant.

\section{CAP. IX.}

\section{De contractibus sine scripto compositis.}

H $\mathrm{HC}$ autem omnia tenere in ${ }^{9}$ civitatibus volumus, nam in agris (ubi

1 Signum crucis intelligit. Nov. 90. in fin. vide l. ult. §. 2. C. de jure delib.

2 De quibus convenit, ut in scriptis fierent.

3 Contractus ex non scripto per testes aut jusjurandum probari potest, $\mathrm{Jul}$. num. 242.

4 Jusjurandum genus esse probationis hine colligere possumus.

5 Hinc sumpta est Authentica, At si contractus $C$. de fide instrum.

- De vi \& potestate hujus constitutionis in quantitate, Jul. hic.

7 Id est, 72, solidos, adde $l$. ult. C. si certum.

8 Non hoc ait, Rerum vilium non admitti petitionem.

- De vi \& potestate hujus constitutionis in loco, Julian. hic. who were illiterate, ${ }^{1}$ so that nothing may be lacking in observing the greatest care. We have made these provisions concerning written ${ }^{2}$ instruments, but if anyone wishes to make a contract without writing, ${ }^{3}$ it is plain that he must prove its genuineness either through witnesses or by oath; and, according to the decision of the judge, the pursuer shall bring forward witnesses and the defender take the oath ${ }^{4}$ or refer it to the pursuer. But, ${ }^{5}$ however, so that nothing be lacking, it is well to add to the law that this need be observed only in the case of a contract concerning custody of property, when the amount of ${ }^{6}$ one pound ${ }^{7}$ of gold is concerned, but the agreement entered into will remain in force so that men may not sustain great losses from articles of little value. ${ }^{8}$

\section{Chapter IX.}

\section{Concerning contracts concluded without writing.}

WE wish all these things to be observed in cities, ${ }^{9}$ for in the

1 The sign of a cross is understood. Eod.

2 Concerning which it is agreed that they are to be made in writing.

${ }^{3}$ A contract without writing can be proved by witnesses or oath. Jul. num. 242.

4 Hence we are able to gather that an oath is a species of proof.

${ }_{5}$ The Authentic, At si, etc., is derived from here.

- Concerning the extent and authority of this ordinance regarding value, see Julian.

7 That is, 72 solidi, eod.

${ }^{8}$ It does not say that a petition regarding small matters will not be heard.

Concerning the extent and authority of this ordinance as to place, see Julian. 
multa simplicitas ${ }^{1}$ est, \& neque scribentium aut testium multorum copia est) quæ hactenus apud eos valuerunt, \& nunc sint etiam firma: hoc enim \& in ipsis testamentis quibus maxime studemus, jam à nobis sancitum ${ }^{2}$ est. Valeat itaque lex in omnibus quæ ${ }^{3}$ post ${ }^{4}$ hæc facienda sunt instrumentis \& contractibus: quod enim jam transivit, cur quispiam sanciat? Hanc autem legem peperit contentionum multitudo factarum quidem in litibus, apud nos autem introductarum quatenus quotidie inter sese contendere homines compescamus, præauferentes eis altercationes per legislationis subtilitatem.

\section{Epilogus.}

$\dagger$ Quapropter convenit tuam eminentiam hæc cognoscentem, manifesta omnibus facere subjectis, \& qui hic sunt, \& qui in gentibus: etenim ad alios gloriosissimos præfectos, \& qui in Hesperia sunt, 5 \& in Libya, \& qui in Septentrionalibus (dicimus autem in Illyrico) scripsimus, ut omnis nobis respublica

1 Rusticorum simplicitas summa est: ideoque rusticitas dicitur innocens \& quieta. l. 3. Cod. de defensor. civit. Remittitur rusticitati solennitas ex acta testamenti faciendi, ut hic: \& l. 31. C. de testam. ut \& in nuptiis, c. 4. in fin. j. eod. Volunt etiam ignosci rustico, propter ignorantiam investituram intra tempus statuto definitum non petenti. $l$. 25. $\$ .1$. ff. de liberis \& posthumis. Alio sensu dicitur rusticitas, id est, imperitia, quæ potest etiam in urbanis hominibus esse, ea non excusat semper à tutela, $l$. 6. $\S$. 19. ff. de excus. nunquam vero à pœna edicti de in jus vocando, $l .2$. C. de in jus vocand.

2 De testamento ruri facto. vide $l .31$. C. de testam.

${ }^{3}$ De vi \& potestate hujus constitutionis in tempore. Julian. hic.

${ }^{4}$ Vid. l. 7. C. de legibus.

5 Italia. country (where there is much simpleness $^{1}$ and a scarcity of writers or witnesses), whatever has been laid down up to now we confirm, and we decree ${ }^{2}$ the same with regard to wills, to which we have given special care. Thus this law shall only be valid in respect of any instruments or contracts which ${ }^{3}$ may be made hereafter, ${ }^{4}$ for why should we sanction what already has occurred? The multitude of legal disputes has necessitated this law which we have laid down to prevent men from almost daily disputing with each other, and by means of the restriction of the law to remove reason for such altercation.

\section{Epilogue.}

Wherefore it is right that Your Eminence, on receipt of this law, shall announce it to all our subjects, either here or in the provinces: and we have addressed it to the other most glorious Prefects in the West ${ }^{5}$ and in Libya, and in the North (we mean in Illyria), so that what we have decreed to avoid

1 The artlessness of country people is great, and on that account country life called simple and tranquil. $l .3$, Cod. de defensor. civit. The solemnity required in making a will is not demanded in the case of the country people, eod. For they are willing to overlook the ignorance of the country person who fails to comply with the time laid down by Statute. In another sense rusticity is used for a lack of skill which also may happen in the case of a city man, and does not excuse him from filling the office of tutor, eod., and at no time indeed from the penalty laid down in the Edict, eod.

2 Concerning the making of wills in the country, see $l .31, C$. de testam.

3 Concerning the extent and authority of this enactment as to time, see Julian.

4 Eod.

5 Italy. 
plena fiat hac lege subjectorum disputes among our subjects will medente concussionibus. Dat. be known throughout the whole prid. Non. Jun. CP. Imper. DN. Empire.

Justin. PP. A. Anno xir. Johanne Given at Constantinople, on the V.C. Cons. ${ }^{1}$ day preceding the Nones of June, during the 12 th year ${ }^{1}$ of the reign of the Emperor Justinian and the Consulate of John.

1 Id est, anno 538.

1 That is, A.D. 538. 


\section{CUJACIUS: EXPOSITIO, NOVEL. LXXIII.}

\section{NovelLA LXXIII.}

\section{De Instrumentis.}

INANE est chirographum quod nullis testibus, nullisque subscriptoribus confectum est, quod que nulla literarum comparatione confirmatur: non est omnino inane, quod literarum comparatione confirmatur, nam deferendi jurisjurandi (quod hic extremum subsidium vocat litium finiendarum) occasionem judici dabit. Non quod teste uno vel duobus: nam et si testis unus non debeat movere judicem ad ferendum jusjurandum sine chirographo (ut in Feudis docuimus) movebit in hanc rem merito tamen judicem chirographum, et testis unus vel duo. Firmissimum autem, id est, quod trium testium præsentia vel subscriptione confirmatur, licet comparatione literarū non cōfirmetur, cūm et sine chirographo tres testes sufficiāt: et ita firmissimum quoque est forense instrumētum, quod tabellionis mandatu amanuensis ${ }^{1}$ eius scripsit, et complevit, vel scripsit tantum, tertia persona veluti argentario adnumerante pecuniam, nam hi tres tabellio, amanuensis, argentarius, pro tribus testibus habentur: et si consentiant horum testimonia, constat fides rei gestæ satis, etiam sine scriptura. Sed si nullus intervenerit amanuensis vel argentarius, præter tabellionem

1 Tabellio vero qui amanuensis nunc vel argentarius dicitur. Cod. Theod. ad l. Com. de falsis (ix. 19).

\section{Novel LXXIII.}

\section{Concerning Instruments.}

A DEED made without witnesses or subscriptions, which cannot be verified by a comparison of handwriting, is worthless. It is not entirely worthless if it can be verified by a comparison of handwriting, for the judge is afforded an opportunity of referring the writer to oath (which in this Novel is called the last resort of litigation). One or two witnesses do not suffice, and a judge may not proceed to a reference to oath where there is only one witness and no deed (as we have shewn in Feudis); but where there is a deed and either one or two witnesses the judge may have the witnesses put on oath. That is best established where confirmation is obtainable by the testimony of three witnesses who were present or who subscribed even if no confirmation is obtainable by a comparison of handwriting, for even without a deed three witnesses suffice. Hence a notarial instrument is beyond dispute if vouched for by a tabellio, the clerk who wrote it at the tabellio's order, and a third witness, say a banker, who counted the money, and should the testimony of all three coincide, the deed is valid apart from the handwriting. But if there was no clerk and no 
duorum vel trium testium præsentiam, aut subscriptionē desidero ex sententia hujus Novellæ. Quid igitur? Tabellionis solius fides non sufficit, forense instrumentum publicum testimonium non habet: ita videtur, hoc jure censetur id solum quod actis insinuatum est apud magistrum census, vel magistratus municipales, vel defensores plebis. Strinxi breviter sententiam hujus Novellæ, et dilucidius tamen forte, quam in Novel. 49. Id non est omittendum, hanc in instrumentis tantum eis diligentiam exigi quæ in urbibus fiunt, et quæ superant libram auri, non in eis quæ ruri fiunt nam et testamentis quæ ruri fiunt, diligens observatio remittitur, l. ultim. C. de testament. Sed et majorem exigit in chirographis quæ excedant. L. libras auri, l. ultim. Cod. si cert. pet. nam subscriptionē exigit trī̄ testium: nec contenta est præsentia, quæ hæc Novella tamen omni in summa videtur esse contenta. Completionum. Prius enim solent tabelliones contractus scribere in scedula, deinde complere in mundo, ut patres familias rationes suas in adversariis primum, deinde in codice [ut docui Novell. 44]. Quinque hi sunt, tabellio, tabularius, tres testes, quoniam tres testes Novella exigit. Sed in forensi instrumento putem sufficere duos, propterea quod tertii vicem explet tabellio. Sed tamen si ex abundanti duobus fuerit adjectus tertius, ita connumeratis tabulario et tabellione fuerint quinque. banker, I require (following the meaning of this Novel) besides the tabellio, two or three witnesses either present or subscribing. What then? A tabellio of himself is not sufficient as a witness, nor is a notarial instrument in Court its own evidence. Thus it appears that only a deed which has been recorded in the register of the Master of the Census, or by the city magistrate, or the defensor civitatis $^{1}$ is public evidence. I have briefly summarised the purport of this Novel, and possibly dealt with the matter more clearly than when expounding Novel XLIX. It is to be noted that this special care is only demanded in regard to deeds made in cities, and in these cases in which more than one pound in value of gold is at stake, not in those made in the country, for diligent care is not required in testaments made there (loc. cit.). But greater diligence is required in deeds where the subject involves more than fifty pounds of gold in value (loc. cit.), for three witnesses are then necessary. Their mere presence is not enough, although this Novel (i.e. 73rd) is satisfied therewith for any sum.

Completiones: Tabelliones are accustomed to write contracts on a leaf of paper and thereafter draft a finished document just as masters of houses enter their accounts first in a memorandum book and afterwards in a ledger [as I have shewn in Novel XLIV.]. There are required five witnesses, the tabellio, his clerk [the tabularius], and three witnesses, since this Novel requires three witnesses.

\footnotetext{
1 Defensor civitatis. See Chapter V. p. 29 , supra.
} 
But in a notarial instrument $I$ should think two witnesses suffice, because the tabellio fills the place of the third. Nevertheless, should a third be added to the two, by counting in the tabellio and the tabularius we get five. 


\section{APPENDIX B ${ }^{1}$}

\section{COD. THEODOS. LIB. VI. TIT. X.}

\section{DE PRIMICERIO ET NOTARIIS.}

\section{Titvlus $\mathrm{X}$.}

Lib. XII. Cod. Ivst. Tit. VII. De Primicerio \& Secundicerio \& Notariis: Cæterum hine SpectaBILIVM ordo incipit. Idemque ordo obseruatur in Notitia: v. quæ noto ad $l$. 21. inf. de petitionib. lib. 10. De Secundicerio Notariorum v. l. 21. inf. de petitionib.

I. (a) Imppp. Gratianus, Valentinianus \& THEODOsIVS AAA. Eutropio PP. (b).

PrACIPVA est nostræ pietatis intentio circa Notariorum nomen: atque ideo si vnquam huius Ordinis viri laborem quiete mutauerint, (c) vel senectute posuerint, (d) seu cum (e) alia dignitate post hanc (f) qualibet vsi sunt, non omittant (g) prioris vocabulum militiæ, sed compendium sequentis honoris adsumant; Et si quis, ex Officio, vel præcipuæ (h) Sublimitatis tuæ temerarius (i) ad Census Discussiones, Peræquationes, aliam denique vllam rem $(\mathrm{k})$ inquietator extiterit, Officium suum nouerit, vel leuis (l) culpæ offensione detecta, grauis multæ discrimine fatigandum, \& Numerariorum corpus, extincto iniuriæ auctore, minuendum. Dat. XVII. Kalendas Iul. Thessalonicæ, Gratiano V. \& Theod. I. AA. Conss. [380.]

\section{Notae.}

(a) Lex 1. Cod. Iust. eod. tit. GOTHO. FREDVS.

(b) Eutropius hic PP. Orientis: de quo mox. IDEM.

(c) Vel abiecerint. add. Tribon. satis incondite: quid enim aliud est laborem quiete mutare, quam quod ipse abiicere vocat? Cæterum MS. habet, mutuauerint. IDEM.

(d) Pro deposuerint. IDEM.

(e) Cumulata, vt $l$. 14. inf. de proximis; cuius similis dispositio. IDEM.

(f) Posthac. Cod. Iust. Istud tamen malo. IDEM.

(g) Ita quoque Cod. Iust. malim tamen amittant, vt $d . l$. 14, adiectu alterius dignitatis perire non patimur. IDEM.

(h) Ita quoque Cod. Iust. sed malim, proecipue. IDEM.

(i) Temerario adsensu in discussiones, \&c. ita Cod. Iust. male: de quo mox. IDEM.

(k) Veluti ad exactiones, vt $l$. 3 . inf. de honor. codicillis: operis exstructiones, ratiocinium Nouella Theodosii 16. in f. IDEM.

(1) Similes locutiones vid. $l$. 3 , sup. de inoff. testam. l. 1. inf. de libertis \& eorum liberis: $l$. 28 de hareticis : vbi plenius. IDEM.

\section{Commentarivs. ${ }^{2}$}

Privilegia Notariorum, ( $\beta \alpha \sigma \iota \lambda_{\iota}$ kov̀s

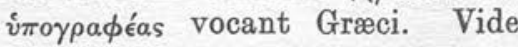

1 Although Justinian abrogated the Theodosian Code, the historical significance of this Title in regard to the subject under examination remains unimpaired. As the original of Theodosius is brief and easily readable, and as the Commentarius on each section consists largely of references, it has not been deemed necessary to append an English calendar.-J.C.B.

2 Marvillius, Lepzig, 1737. 
vel Zosimum Lib. 3. cap. 4. Lib. 5 .

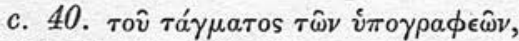
Lib. 5, cap. 44.) etiam ex-Notariis, id est, iis qui vel vltro eam militiam post laborem reliquerunt, vel deposuerunt, vel alia dignitate cumularunt, seu commutarunt, seruari oportere definit hac. $l$. Theodosius M. Imper. In qua tria notanda sunt: Primo, Præfatio: Ea scilicet Theodosius profitetur, Pracipuam intentionem suam esse circa Notariorum nomen, id est, præcipuo studio \& affectu sese Notarios prosequi. Fuit hæc scilicet Notariorum Schola seu ordo Collegii alios inter magnæ dignitatis: vnde \& Militia nobilis dicitur l. vlt. hoc tit. Præclarum Collegium, l.vlt.sup. de Senatoribus. Militia, qua non illustrior extat Altera, Claudiano in Epithal. Pal-

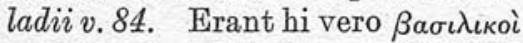

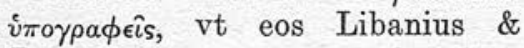
Zosimus non vno loco, lib. 3. \& 5. \& Socrates $l i b .7$, cap. 23. \& vetus Auctor apud Suidam verb. Av $\xi^{\prime}$ v́rios appellant, qui videlicet in consistorio Principis Acta excipiebant (de quibus Ammianus Marcellinus quoque passim) vnde l. 7 de privil. eorum qui in S. P. diserte dicuntur Notariorum officio fungentes inter Consistorii secreta, \& Notariorum Primicerii de Consistorio Principis discedere, $l$. 2. prox. \& ab Ammiano Marcellino lib. 30. cap. 2. Notarii Principis: vt \& a Cassiodoro VI. Var. 16. in formula Notariorum, qui Principis secretum \& consilium his committi ait, Principisque curis assidua lucubratione militare. Secretum scilicet, quia in consistorio Principis Acta \& Secreta notabant. Alius vero, ab his Notariis, quem Vopiscus in Aureliano c. 36. secre- torum Notarium vocat: hic enim est, quem Zosimus lib. 1. cap. 26. de eadem re agens, $\tau \dot{\omega} \nu$ $\dot{\xi} \xi \omega \delta \epsilon \nu$

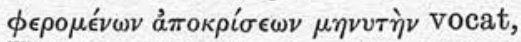
Victor Schotti c. 35. ministrum, cui secretorum officium crediderat. Nempe Notarii indicium faciebant \& foras efferebant Imperialia responsa: vnde \& Orationes Imperatorum per Primicerium Notariorum in Senatu aliquando recitabantur: $l$. 14 . sup.de Senatoribus. Quare cessent insaniæ quorundam, de Notariis ad secreta, \& a secretis. Horum opera vsi Principes extra ordinem peregre sæpe tanquam perspicacibus: vid. Marcellinum lib. 26 . cap. 5. tanquam sagacibus ad perducendos reos; idem testis, lib. 14. cap. 5. vt adsisterent cognitionibus, interrogationibus, lib. eod. cap. 9. \& 11. lib. 15. c. 3. lib. 28. cap. 1. \& Sozomenus lib. 4. cap. 10. Missi etiam ab Imperatoribus Cæsarum actibus explorandis Ammianus lib. 1\%. cap. 9. lib. 21. cap. \% obseruandisque traiectibus lib. 20. cap. 9. conatibus etiam alicuius \& ad tuendam prouinciam positi lib. 22. c. 11. lib. 26. cap. 5 . Commeatus frumentarii his mandati: Symmachus, lib. 10, ep. 31 . Denique cum mandatis in prouincias missi, $l$. vn. sup. de Mandatis Principis, vbi plura: Episcopique per hos sedibus suis restituti, vt Chrysostomus ipso teste ep. ad Innocentium tomo IV. Francof. edit. p. 595. ipsique quæ e re essent Imperatoribus suggerebant: Ammianus lib. 26.cap. 7. Cæterum peculiarem erga eos affectum, vt alii Principes, vid. Cassiodor. $d$. form. 16. ita hic Theodosius M. prodit hac constitutione ad Eutropium PP. emissa. Quod quidem in memo- 
riam mihi reuocat. quod Gregorius Nazianzenus ep. 137. 138. hunc ipsum Eutropium a doctrina, eruditione, \& eloquentia summopere commendat: vt videatur omnino Eutropius huius leg. promulgandæ Theodosio auctor fuisse: prostudio, quo in literatos (cuiusmodi sane erant Notarii) ferebatur. Verum hæc coniectura est.

Nunc de sententia huius leg. Secundo igitur, quod hac leg. præsupponitur \& indicatur, priuilegio hoc subnixi fuere Notarii, vt ad Census, Discussiones, Peræquationes, aliam denique vllam rem inquietari non possent; id est, vt Censitorum, Discussorum, Peræquatorum onus his impingi non posset: Ad Census, ait lex: recte enim ita hic legi proxime sequentia ostendunt: non adsensu, vt perperam Cod. Iust. Idque etiam egregie confirmat Zenonis lex. 2. circa med. Cod. Iust. eod. tit. vbi hæc immunitas ex hac leg. repetitur: vacationem, inquit, census, discussionis percequationis \& cuiuslibet alterius rei habituros. vid. \& Nouellam Theodosii 16 . de postulando, circa fin. Ad census vero, \&c. pariter vt $l$. 3. de honorar. codicil. ad exactiones. Ergo Censitoris, Discussoris, Peræquatoris munus his iniungi non potuit: de quo alioquin Censitorum, Peræquatorum munere libro 13. tit. 11. de Discussoribus, lib. 11. tit. 26. Eadem vero immunitas tributa \& Domesticis \& silentiariis, l. 2. \& 3. inf. de domest. \& protectorib. Eadem \& Curialibus iis qui Præsides \& Rationales reuera suerunt, l. 3. inf. de honor. codicil. Ex archiatris l. 2. inf. de Medicis. Addit lex ad aliam denique vllam rem, veluti exactiones, d. l. 3. inf. de honor. Codicil. operis exstructiones, ratiocinia, d. Nouella 16 . Hac omni immunitate donati \& Scriniarii S. Palatii post viginti annorum militiam, $l$. \%. 8. inf. de proximis.

Tertio loco succedat nunc ipsa Legis dispositio. Nempe Theodosius M. priuilegia superiora constare iubet etiam ex-Notariis : Idque, siue laborem quiete mutauerint, id est Notarii munus vitro abdicauerint, vel vt barbare satis Tribonianus, abiecerint, siue ob senium deposuerint, siue denique etiam cum alia (forte commutata) dignitate post hanc qualibet vsi sunt: id est, post Notarii officium depositum, aliam dignitatem sortiti sunt. Non igitur tantum si ad quietem secesserint, verum etiam si continuato labore aliam dignitatem susceperint. Quod vtrumque \& alias obtinuit, vt munere defunctis eadem priuilegia adhuc competant: \& alia maiore puta dignitate auctis constent. Maior scilicet dignitas nulli debet circa prioris dignitatis seu militiæ priuilegia præiudicium facere: $l$. 3 . Cod. Iust. de dignit. si modo ea lex a Triboniani facinore immunis est. Id enim singularis priuilegii loco Theodosius Notariis sese concedere indicat. Certe Honorius postea Scriniariis idem concessit l. 14. inf. de proximis sacror scrinior, quæ lex cum hac conferenda omnino est: vt \& decurionibus \& silentiariis $l$. 2.3. inf. de decurionib. \& silentiar. Eademque immunitas tributa Ex-archiatris, l. 2. inf. de Medicis. Eadem tributa \& Palatinis, de quibus $l$. 3. \& 5. inf. de priuil. eorum qui in sacro Pal. Iisdem sane tributum, vt Senatores facti a glebali collatione immunes 
essent: l. vlt. sup. de Senatoribus. Ergo Notarii munere suo defuncti $a b$ illis muneribus immunes sunt seu excusantur: cum alias Honoratis dignitate functis, deque Palatio exeuntibus hæc munia a ludicibus sæpe iniungerentur pro rerum necessitate: vid. l. 3. inf. de honor. codicil. vbi dicam, \& d. l. 2 . inf. de Medicis : l. 2. inf. de decur. \& silentiariis.

Sequitur sanctio legis: Nempe Officio Rectoris prouinciæ minatur grauem multam, \& Numerario exauctorationem. Numerarii scilicet huiusmodi munerum iniungendorum curam sustinebant, de quo suo tit. inf. de Numerariis, lib. 8.t. 1. Idem vero interdictum anno proximo ab eodem. Theodosio Numerariis circa omnes ex Aula decedentes, \& post emeritam missionem; l. 11. infr. de priuil. eorum qui in sacro palatio.

\section{II. (a) Iidem AAA. ad Valerianum (b) PV.}

Notariorvm Primicerios, si, prout eorum voluntas fuerit, de Consistorio nostro, sine administratione (c) discesserint, non solum Vicariis anteponi, sed etiam Proconsulibus (d) æquari sancimus, ita vt nihil nisi tempus intersit. Eodem honore atque eodem ordine sequens Primicerium Tribunus ac Notarius perfruetur. Alios porro Notarios \& Tribunos Vicariis iubemus æquari, ac, si priores id (e) vocari cœperint, anteferri. Ad (f) vero Domesticos \& Notarios Consularibus simili ratione conponimus; \& cetera. Dat. IIII. Kalend. April. Acc. XII. Kal. Maii. Syagrio \& Eucherio VV. CC. Coss. [381.]
Notae.

(a) Abest hæc lex a Cod. Iust. Memoratur ea $l$. 13. infr. de priuil. corum qui in S. Pal. Iungendæ vero illi lex 2. inf. de proximis Comitib. dispos. \& lex 5. de honorar. Codicillis. GOTHOFREDVS.

(b) Valerianus P. V. Romæ scilicet A. D. 381. cui præter hanc \& duas illas, inscribuntur adhuc lex 2. de equis Curulibus. l. 6. 7. 8. de scanicis. IDEM.

(c) Magistri enim officiorium dignitate sæpe decorabantur: dicam ad $l$. vit. infr. IDEM.

(d) Proconsules Vicariis superiores, v. \& Notit. Imper. Inter Spectabiles primi, de quo ad $l$. prox. quoque \& ad $l$. 1. de Com. rei mil. IDEM.

(e) Id est, si prius Notarii \& Tribuni fuerint, Vicarios posteriores tempore vincunt. IDEM.

(f) $\gamma \rho$. At vero. IDEM.

\section{Commentarivs.}

DE PRIMORVM (vt eos quoque vocat Ammian. Marcellinus, lib. 29. cap. 2.) inter Notarios, de Consistorio exeuntium sine administratione nouaque dignitate, ordine; est hæc Gratiani Imp. lex : Quæ pars est prolixioris Gratianeæ constitutionis de Honorariis codicillis \& dignitatibus tum Palatinorum, tum extra-Palatinorum: vnde supersunt duæ adhuc Leges puta lex 5 . inf. de honorar. codic. lex 2. de proximis Comitib. dispos. quæ proinde huic coassandæ veniunt.

Nos de hac nostra nunc agemus: Vbi obseruandum, in ordine vel schola Notariorum eminentiores seu primos quosdam fuisse, qui hac $l$. nominantur. Erat scilicet Primicerius Notariorum: erat, Primicerium sequens Tribunus \& Notarius; erant alii seu ceteri Notarii \& Tribuni, erant denique Domestici \& Notarii. Primicerius Notariorum (cuius $h . l$. mentio fit \& l. 3. 4. inf. \& l. 14. sup. de 
Senatoribus cui iungenda $l$. 33. inf. de petitionibus, \& l. vn. inf. qui $a$ prabitione tironum, \& Nouella Theodosii 32. de Metatis, \& apud Renatum Profuturum Frigeridum, referente Gregorio Turonensi lib. 2. cap. 9.) ab Ammiano Marcellino vocatur Primus omnium Notariorum, lib. 26. cap. 6. in gestis $A n$. 365. Socrates lib.7. c.23. eum vocat

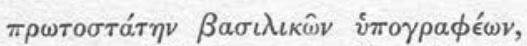
Zosimus lib. 5. cap. 40. vbi de Ioanne Primicerio agit ă $\rho \chi o \nu \tau \alpha \tau \hat{\omega} \nu$

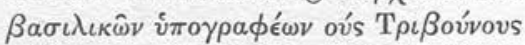

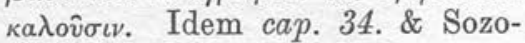

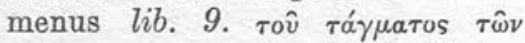

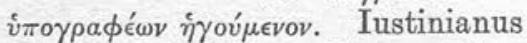
Nouella 8. in Edicto adiecto, retinet

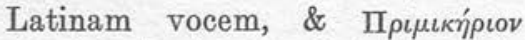

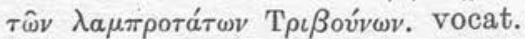
Primum locum militiæ nobilis adsectus, $l$. vlt. inf. Ex ea dignitate Iouianus ad imperium conscendit, teste Ammiano d. loco. Sub huius Primicerii dispositione erat omnis Dignitatum \& Administrationum notitia, tam militarium quam ciuilium, scholas etiam \& Numeros tractabat, vt totidem verbis Notitia Imperii scribit. Idque ipsum indicat Claudianus huius rei sciens, ipse quippe Tribunus \& Notarius, in epithalamio Palladii, v. 83. seq.

- - - Paulatim vectus ad altum,

Princeps Militia, qua non illustrior extat

Altera, cunctorum TABVLAS assignat HONORVM:

Regnorum tractat NVMEROS, CVNEOSQVE recenset,

Sparsas Imperii vIRES constringit in vnum

Depositvm; quae Sarmaticis custodia ripis,
Qua scuis obiecta Getis, quœ Saxona fronat,

Vel Scotum LEGIO, quantum cinxere cohortes

Oceanum, quantum pacatur MILITE Rhenus.

Qui Claudiani locus geminus est cum altero Notitia: \& omnia respondent: Tabulas honorum vocat, Notitiam omnium dignitatum; Regnorum Numeros ab eo tractari ait, similiter Notitia, Numeros a Primicerio Notariorum tractari, quod etiam ostendit $l$. 2 . Cod. Iust. eod. tit. Idque in Commentario, cui laterculi maioris nomen, quod etiam Notitia Imperii docet \& exhibet; quod Depositi voce Claudianus indicat: sparsas Imperii vires constringit in vnum Depositum. Laterculum scilicet iamdiu pro Tabula, Indice \& Commentario vsurpatum apud Tertullianum, non tantum in lib. $a d u$. Valentinianos, verum etiam lib. 1. aduersus Nationes, quem nos edidimus: cap. 13. de solis culta. Vos certe estis qui etiam in laterculum septem dierum Solem recepistis \& ex diebus ipsorum (ipsum) pralegistis, quo die lauacrum subtrahatis, aut in vesperam differatis, aut otium \& prandium curetis. Eundem Primicerium Notariorum reperio constitutiones Principum in Senatu quandoque recitasse, l. 14. supr. de Senatoribus. Primicerium sequebatur qui hac lege vocatur, sequens Primicerium Tribunus \& Notarius, qui eadem ratione Secundicerius Notariorum vocabatur, in l.21. inf. de petitionib. Ammianus Marcellinus lib. 29. circa principium, secundum inter Notarios gradum vocat, de quo mox plura. Hunc \& superiorem 
idem Ammianus summates Notariorum vocat lib. 26. cap. 6 . Hos sequebantur alii seu cæteri Notarii Tribuni. Quorum non hac tantum lege mentio fit; verum etiam l. vn. supr. de mandatis Principum l. 1. inf. Qui a prabitione tironum. Qui Tribuni residui ordinis vocantur, $l$. 3. infr. prox. Eorundem frequens mentio fit apud Ammianum Marcellinum lib. 26. cap. 6. vbi nominatim Notarium \& Tribunum vocat. Et lib. 1\%. cap. 5. lib. 19. cap. 9 \& lib. 20. cap. 4. Fit \& Tribunorum \& Notariorum mentio in duabus veterib. inscript. apud Gruterum, pag. cccxci. num. 5. \& p. CCCCLXIV. n. 8. Cæteroquin Notariorum simpliciter frequentissima apud eum mentio lib. 14. cap. 5. 9. 11. lib. 15. c. 3. lib. 20. cap. 4. 9. lib. 21. cap. 4. lib. 22, c. 3. lib. 26. cap. 5. \%. lib. 28. cap. 1. Fit etiam horum Tribunorum \& Notariorum mentio apud Symmachum lib. 5. Epist. 37. lib. 10. Epist. 36 \& 39. apud Ambrosium, Augustinum, Paulinum: Deque iis sunt duæ veteres inscriptiones de Claudiano, \& Petronio Maximo. Huiusmodi Tribuni, \& Notarii a Principis latere ferme mittebantur Legati, de quo plenissime ad $l$. vn. sup. de Mandatis Principum.

Præter hos Tribunos Notarios erant alii qui Domestici \& Notarii vocabantur, quorum lege quoque proxima mentio fit, vbi familiares Principi dicuntur his verbis: Reliquos, quos Domesticum inter Notarios \& familiares nobis nomen insinuat. Cæterum de horum omnium dignitatibus id $h$. $l$. a Gratiano cauetur, (vt \& a Theodosio M. pariter $l$. prox. 3. inf.) vt Primicerii etsi sine administra- tione discesserint: (\& Secundicerii) Notariorum dignitate perfuncti, vicariis diœceseon præferantur, \& Proconsulibus exæquentur. Quod etiam ex Imperii Notitia liquet: In tantum vt cum Proconsulibus temporis prærogatiua certent: Sequentes vero Tribuni \& Notarii vicariis exæquentur, \& cum iisdem temporis prioritate decertent: Domestici vero \& Notarii Consularibus componantur.

Vbi obseruandum primo, Secundicerium eodem honore atque eodem ordine perfrui, ex hac $l$. cum Primicerio: pariter vt in sp. leg. 21. inf. de petitionib. hi scilicet summates Notariorum erant: de quo iam supra.

Secundo obseruandus dignitatum ordo; Proconsules, Vicarii, Consulares, qui eodem modo obseruatur in d. l. 5. inf. de honor. Cod. quæ huic coniungenda est: \& in Notitia Imperii. Et $l$. 21. inf. de diversis officiis: $l$. 15. 16. de ponis, $l .13$. inf. de accusationib. Sed \& illud notetur, inter Spectabiles, de quibus ab hoc titulo tractari incipit, Proconsules primo loco constitisse, de quod vid. \& $l$. 1. inf. de Comitibus rei militaris: vbi dicam, \& Notitiam Imperii.

In tantum vero (quod Tertium) inter Proconsules hi stetere, vt altissimarum quoque Dignitatum numero eos haberi antea voluerir Valentinianus, constitutione sua de gradibus dignitatum: sic quidem vt Comites quoque rei militaris primi gradus per transmarinas prouincias vincerent: $\quad$. 1 . inf. de Comitib, rei mil. \&, quod magis est, eos quoque qui honorarios Illustris Magisterii Equitum codicillos adepti erant, $l$. 4. inf. de honor. codicill. quæ duæ leges inter se 
coassandæ sunt, velut prædictæ Valentinianeæ constitutionis de gradibus Dignitatum partes. Cui conuenit \& quod Cassiodorus scribit VI. Var. 16. in fin. vt dicam ad eas leges.

Quarto notetur, Honorarios Palatinos istos cum actualibus

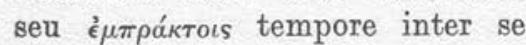
certare h. $l$. \& $l$. proxim. 4. in fin. cui iungenda lex. 6. inf. de honor. codicillis. Quod Palatinis singulari priuilegio datum, cum alioquin extra-Palatini honorarii cum

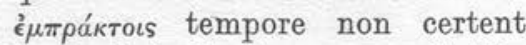
l. 5. inf. de honorar. codicillis, quam huic coassandam dixi \& $d$. l. 6. Quod ipsum constituitur \& de aliis honorariis Palatinis ac nominatim de Proximis scriniorum \& Comitibus dispositionum d. l. 2. inf. de proximis, quæ \& ipsa huic coassanda venit. Et hæc quidem illa est Gratiani constitutio quam Valentinianus Iun. frater eius memorat firmatque $l$. 13. inf. de priuil. eor. qui in sacro palatio.

Quinto notetur, dignitatem eorum computari ab eo tempore, quo Notariatu seu Consistorio discesserint, $h . l$. Idque in proximis quoque scriniorum \& Magistris dispositionum obtinet: $d . l$. 2 . de proximis. Verum immutatum \& hoc l. 3. prox. \& illud $l$. 4. 10. inf. de proximis.

Tandem obseruetur, Primicerios Notariorum de Consistorio discedere dici, non quasi Consistoriani Comites fuerint, quod hinc colligebat Vir doctus: verum quia Notariorum munus in Consistorio Principis erat. Vnde \& l. \%. infr. de priuil. eorum qui in S.P. dicuntur Notariorum officio fungentes inter Consistorii secreta: de quo ad $l$. 1. huius tit. Sic \& in inscriptione statuæ Petronii Maximi apud Gruterum p.ccccxuIx. n. \%. PRIMaevVs in consistorio SACRO TRIBVNVS ET NOTARIVS MERviT: Sidonius Carm. 23. v. 213.
Et iam te Aula tulit, piusque Princeps

Inter conspicuos statim locauit

CONSISTORIA quos habent TRIBVNOS.

\section{III. (a) Iidem AAA. Floro (b) PF. P. (c).}

Notariorvm Primicerium in numero Proconsulum (d) habemus, tanquam comites eis semper fasces (e) cum curialibus (f) dederimus; Prætorianos longe ab hoc abducimus, vt qui ad Tribunatum nominis huius accesserint, Orientis siue Ægypti Comitiuæ videantur insulas consecuti: Tribunos residui ordinis nemo dubitet Vicariis exæquandos \& præferendos his quos adepti (g) honoris præcesserint: reliquos vero quos Domesticum inter Notarios \& familiares (h) nobis nomen insinuat, parem gradum cum Consularibus obtinere sancimus, \& cetera. Dat. Id. Decemb. Constantinop. Syagrio \& Eucherio Cons. [381.]

Notae.

(a) Iungenda huic lex 6, infra de honor. Codicillis. GOTHOFREDVS.

(b) Florus PP. Orientis sub Theodosio M. vid. Prosopogr. IDEM.

(c) Prceposito, male in Cuiacii edit. anter. IDEM.

(d) Proconsules primi inter Spectabiles, dicam ad $l$. 1 . de Comitib. rei milit. IDEM.

(e) Fasces Proconsulum b. l. \& leg. 7. de honor. codicil. vid. Gloss. Th. IDEM.

(f) An Curulibus? Notum, Insignia Consulum \& Proconsulum fuisse Fasces \& Sellam Curulem: vid. \& l. 7. inf. de honor. codicillis. An 
securibus? vt l. 7. inf. de honor. Codicil. \& Nouell, Iust 30. cap.6. de Procons. Cappadocice: Prius placet. IDEM.

(g) $\gamma \rho$. Adeptis honoribus: nisi malis adeptu honoris. IDEM.

(h) Nolo mutari in familiare. IDEM.

\section{Commentarivs.}

Sententia huius legis eadem pene est, quæ superioris; vt etiam apparet ex coniunctione $l$. 6 . inf. de honor. Codicillis. In eo tantum differunt, quod Dignitatem Primiceriorum Tribunorum computari velit Theodosius ab eo statim tempore, quo Primiceriatum \& Tribunatum adepti sunt. Tanquam, inquit, Comites semper eis fasces cum curulibus dederimus: de quo dixi ad $l$. sup. Simile quid vero $a b$ eodem constitutum l. 4. inf. de proximis, cum antea aliter obtineret. Item hoc amplius hac Theodosii constitutione continetur, nempe Tribunos \& Notarios Prætorianos non eadem qua Primicerium Notariorum dignitate consendos, sed proximo post illum gradu constituendos, \& non Proconsulibus, sed Comitibus Orientis vel Egypti exæquandos. Proximi scilicet Proconsulibus gradu fuere hi duo Comites, quibus adiungendus tertius Comes Ponticæ, Comitibus aliis, Ducibus, Vicariis \& Consularibus superiores: vt docet quoque præter Notitiam Imperii, lex vn. inf. de Comitib. \& Tribunis schol. \& l. vlt. inf. de comitib. rei milit. \& lex 21. inf. de diuersis officiis : Et lex 15. 16. inf. de ponis. Cæterum Tribunus Pratorianorum Notariorum hoc ipsum erat inter Notarios Præfecti Prætorio, quod Primicerius inter Notarios Principis: Igitur hic etsi finitima esset Præfecti prætorio dignitas imperatoriæ, \& in officio Prætoriano constituti magnis pariter priuilegiis euecti fuerint, toto tamen gradu Primicerio Notariorum Principis cessit. De quo iam aliquid monui ad $l$. 8. sup. de diversis rescriptis. \& ad $l$. 18. sup. de Prcetorib. Porro horum Prætorianorum Tribunorum \& Notariorum mentio fit quoque in $l .6 . \S .1$. Cod. Iust. de Aduocatis diversorum Iudicum. Et apud Cassiodorum VI. Variar. 3. Militia, inquit, perfunctis (Officialibus) Tribunorum $\&$ Notariorum honorem tribuit, \& milites suos illis excquat, qui inter Proceres mixti nostris conspectibus obsecundant. Quæ Cassiodori formula dignitatis Prætorianæ breuiarium elegans continet: Idem $X I$. Var. 8. de corniculario, qui egreditur: Et ideo Antianum qui Pretorianis inculpabiliter paruisse perhibetur obsequiis, inter Tribunos \& Notarios ad adorandos Adspectus properet Principales. Sed \& vetus inscriptio horum Prætorianorum meminit: l. c. ap. Gruterum p. cccclxrv. n. 8. Rufius Prcetextatus V.C. filius Magnifici viri Mariniani Prafecti Prcetorio \& Consulis Ordinarii Qucestor Candidatus, Prcetor vrbanus, Tribunus \& Notarius Pratorianus, \&c.

IIII. (a) Impp. Theodosius A. \& Valent. Cæsar. Hierio PF. P. (b) Orientis.

Eos qui ex Primiceriis Notariorum, ad Inlustrem meruerint Magistri, (c) a vigiliis atque laboribus, procedere summitatem, minime redigendi sunt in ordinem (d) ceterorum, qui honorarios meruerint codicillos: quoniam \& res 
ipsa, quod primum locum sint militiæ nobilis (e) adsecuti, \& publica sæpe (f) impleta commoditas, nunquam otiosos fuisse testatur; \& cetera. Dat. X. Kalend, Octob. Topiso, (g) Theodosio A. XI. \& Valentiniano Cæs. Conss. [425.]

\section{Notae.}

(a) Iungenda huic lex vlt. inf. de honorariis Codicillis. Quæ etiam huic argumento optime respondet. GOTHO. FREDVS.

(b) Male in Cuiacii edit. prioribus Prceposito. IDEM.

(c) Magister $\dot{\alpha} \pi \lambda \hat{\omega} s$, pro Magistro Officiorum $h . l$. \& $l$. 3 , in $f$. inf. de Agentibus in rebus \& magisteria: vt. l. 2. sup. de Qucestor, efficax magisteria. Magisteria dignitas apud Cassiodorum quoque de Magistro officiorum VI. Variar. 6. Hac Magisteria \& Magistri voce vtitur Suidas, \& apud eum incertus Auctor, \& Theophylactus Simocatta hist. Mauric. lib. 2. cap. 3. quos locos notauit Meursius in Gloss.

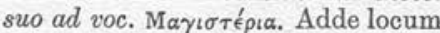
Prisci in Hist. Gothica in Excerpt. Legat. pag. 26. Tom. I. Script. Rer.

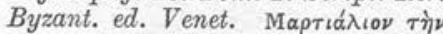

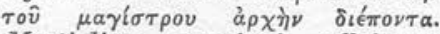
Martialium magistri officiorum munere fungentem. Item $\pi \alpha \sigma \hat{\omega} \nu$

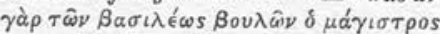

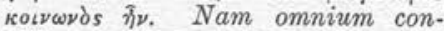
siliorum imperatoris magister est particeps. Hinc etiam Magistriani, vel Magisteriani: do quibus alibi. Et tamen Magisteria quoque potestas $\dot{\alpha} \pi \lambda \hat{\omega} s$ de Magistris militum dicitur, l. 7. inf. de lusor. Danub. \& tit. de apparit. Magisteria potestatis: vt id negantes mirari subeat. IDEM.

(d) De quo vide d. legem. vlt. IDEM.

(e) Militia nobilis Notariorum $h . l$. Præclarum Collegium, $l$. vlt. sup. de Senatoribus; Similiter Zeno, ex h. l. in l. 2. Cod. Iust. eod. tit. IDEM.

(f) Qui Gloriosis obsequiis nihil non Reipubl. adferunt \& decoris: Zeno d. l. 2. IDEM.

(g) Ita quoque rescribendum in $d . l$. vlt. Vrbs porro hæc. Thraciæ fuit: Quanquam aliis Topiro, vel Topiris, vel Toparon, videlicet Itinerario, apud Ptolomæum, \&
Procopium, lib. 3. de bell. Goth. c. 38. \& lib. 4. cap. 11. de edificiis Iustiniani. Primæ Macedoniæ adscribitur in Conciliis, \& nominatim in Chalcedon, vno quoque loco apud Antoninum, Toposium. IDEM.

\section{Commentarivs.}

Honoraria magistri officiorvm, dignitate auctum eum, qui Primiceriatu Notariorum perfunctus est, a cæteris qui honorarios huiusmodi codicillos impetrarunt, distinguit Theodosius Iun. hac leg. quæ pars est constitutionis prolixioris de Honorariis Codicillis, vnde pars altera extat $l$. vlt. inf. de honor. Codic. quæque proinde huic coassanda venit. Alia scilicet \& melior est eorum ratio, qui a laboribus \& vigiliis, (id est post labores) dignitate aliqua aucti sunt: alia, longeque inferior, eorum qui fasces ciuilium partium consecuti, nulla prius laboribus rudimenta posuerunt, vt loquitur lex vlt. inf. qui a prabit. tironum. Et certe nominibus quoque olim proprie loquendo a se inuicem hi distincti fuere: Illi quippe vacantes dicti, hi vero, Honorarii : vacantes scilicet dicebantur, qui post vigilias \& labores vacantes iam \& munere defuncti, pro præmio dignitate aliqua honoraria euehebantur: modo Illustri (vt puta Magistri officiorum, de quo h. $l$. \& Zenonis l. 2. Cod. Inst. eod. tit. Comitis Domesticorum, vt apud Cassiodorum VI. Variar. 11. vid. \& Nouellam Theodosii, de metatis 32. sub fin. \& l. 2. Cod. Iust. vt dignitatum ordo) modo Comitiuæ primi ordinis: hinc Comites vacantes, de quibus est titulus inf. 18. cuius lex vnica huic nostræ prorsus respondet, vbi etiam dicam plura. 
Honorarii vero proprie \& stricte dicebantur, qui vacantibus opponebantur, nudi, imaginarii, \& Codicilarii erant, qui citra administrationem aliquam $a \breve{\zeta} \omega \sigma \tau o$, sine cingulo dignitatem erant consecuti: de quibus dicendi locus erit inf. suo tit. de honor. Codicillis, \& d. tit. de Comitib. vacantib. Et hæc quidem ita distinguenda sunt, \& tamen in Zenonis $l$. 2, seu vlt. Cod. Iust. eod. tit. de Primicerio, Primicerius hic ipse Notariorum post depositam militiam Magistri officiorum infulas pro more sortitus, ac si ipsam gessisset administrationem omnibus vacantibus opponitur, \& præponitur. Verum de hoc plene ad tit. de Comitibus vac. De his igitur hæc Regula seruetur (quam etiam superius consignaui ad $l$. vn. de Consulibus.) Inter pares dignitate personas, vacantes, etsi tempore posteriores, Honorariis, tempore prioribus, prceferri. Neque inter hos tempore certari: verum hos illis indistincte cedere. Quæ vna est exceptio inter alias ad Regulam generalem: qua alioquin, Pares dignitate persona, temporis prioritate inter se certant: de qua dixi ad $d$. $l$. vn. Honorariis igitur proprie dictis, vacantes non connumerantur: quinimo inter agentes, id est, actu ipso administrantes, censentur: $l$. vlt. inf. de Honorariis Codicillis, (quam huic coniungendam dixi) de quo tamen $i b i$ dicam plenius: vid. interim l. 2. Cod. Iust. vt dignit. ordo. Cedunt proinde (vt eo redeam) vacantibus, Honorarii toto gradu: nam (vt eleganter loquitur $d$. $l$. vtt.) nunquam honor delegatus ex debito ei qui ad similitudinem tribuitur, comparari debet: vel (vt l. vn. inf. de Comitibus vacantibus, non minus eleganter loquitur) licet vnum nomen sit, tamen est meritis æstimandum: quæ verba ibi perpendam plenius, \& certe lex hæc quoque nostra eandem rationem in fine suggerit \& indicat: ibi: quoniam \& res ipsa, \&c. Interim obseruandum, Primiceriatu Notariorum perfunctos Magistri officiorum dignitate ferme decorari solitos: vel quia re ipsa postea Magistri Officiorum crearentur. Quomodo Notarios duos Magistros officiorum factos memorat Ammianus Marcellinus $l i b .20$. cap. 9. \& lib. 28. cap. 1. vel quia saltem vacantes vel otiosi iam, hac honoraria dignitate decorabantur: quod præter hanc legem nostram ostendit \& Nouella Theodosii de metatis 32. \& Zenonis lex 2. Cod. Iust. de primicerio \& Notar. idque etiam in partem innuere videtur lex 2. supr. Adeo quidem vt hi cæteris vacantibus, \& Honorariis, seu Codicillariis aliis paris vel eiusdem dignitatis, etsi posteriores tempore prioribus præferrentur: quæ huius legis Sententia est, De quo est omnino Zenonis $d$. lex 2. Cod. Iust. eod. tit. Hoc etiam adiiciendo, vt Primicerius post depositam publicam numerorum solicitudinem, ac si ipsam gessisset administrationem cuius consequitur dignitatem, Magistri officiorum pro antiqua consuetudine infulas sortiatur, omnibus vacantibus, quamuis tempore prcecedentibus prceponendus. Cassiodori locus VI. Variarum 16. in formula Notariorum. Additur etiam perfuncti laboris (id est, primiceriatus) aliud manus, vt si quo modo ad Illustratum, vel vacantem meruerit peruenire, omnibus debeat anteponi qui Codicillariis Illustratibus probantur ornari. 
Vnde absolute colligitur, Primiceriatus meritis datum, vt in vno eodemque titulo dispar esset dignitas aqualiter acquisita Quare \& huius peculiaris quoque ratio habita præ honorariis, in argumento immunitatis a Metatis, Nouell Theodosii 32. Illud quoque monendum, alios $a b$ his esse Tribunos, \& Magistros officiorum, de quibus agitur l. 1. inf. de distrah. pignor. quce tribut. causa: \& l. 1. inf. de paganis sacrif.

Superest, illa expendamus, ad Inlustrem meruerint Magistri, a vigiliis atque laboribus, procedere summitatem: nam ita hic locus interpungendus est: ne quis hic sibi Magistrum a vigiliis atque laboribus fingat; Nempe a vigiliis atque laboribus hic est, post labores $\&$ vigilias emensas: Quomodo $d$. lex vlt. inf. de honorar. codic. quam huic coassandam dixi, in hac ipsa re, emensis sudoribus: Imo id extrema Legis aperte adstruunt. Similiter Zeno l. 2. Cod. Iust. eod. tit. laboris ac sollicitudinis voce hac in re vtitur: \& Cassiodorus VI. Variar. 16. Notarios curis Principis assidua lucubratione militare scribit. Igitur vacantem Illustrem, post labores scilicet indicare voluit Imp. nudisque Honorariis opponere. Haud absimili formula Velleius Paterculus dixit lib. 2. cap. 99. Commeatum acquiescendi a continuatione laborem petiit. 


\section{APPENDIX C}

(1) Testamentum sollemne Mannanis a xli

(2) Fragmentum Instrumenti donat. Gaudioso . xlv

(3) Instrumentum donat. Stephani Greci a xlvi

(4) Instrumentum donat. Sisivera . . . xlvii

\section{(1) TESTAMENTUM SOLLEMNE MANNANIS}

(Spangenberg, No. XVIII.)

I. Asservatur Romæ in bibliotheca Vaticana, scriptum in papyro, longitudine palmarum quinque et dimidiæ, latitudine unciarum sexdecim. Editum est a Marinio "I papiri diplomatici" nro. LXXV. p. 116; annotationes adspersit in pagina $257-261$. $^{1}$

II. Exhibet nobis charta nobilissima testamentum Mannanis cujusdam, conditum anno 572 p. C. n., authenticumque, ex archivis curiæ Ravennatis desumtum, in quibus post recitationem in illa curia factam, ut moris, ${ }^{2}$ asservatum fuerat. Opistographum est, testium enim signacula et superscriptiones haud in involucro testamenti, sed in ipso chartæ dorso ${ }^{3}$ conspiciuntur. Nec tamen holographum est, quippe coram tabellione conditum, et ejus manu conscriptum.

1 Specimen scripturæ exhibet Marinii tabula V.

2 Paull. Sent. recept. Libr. IV. tit. 6. § 1. Ac demum (testamentum in curia apertum et recitatum) signo publico obsignatum in archium redigatur, ut si quando exemplum interciderit, sit, unde peti possit.

3 Conf. Cujac. Observ. et Emend. L. VIII. cap. 15. Salmas. ad Hist. Aug. script. p. 446. Hugo de scribendi origine prima. c. 31 .

Imp. Dño Justino PP. Aug. anno decimo, P. C. ejus anno septimo, sub die V. Kal. Martiar. Indict. octava Ravenn.

Ego Mannanes vir devotus, filius quondam Nanderit, sano corpore, integroque consilio, metuens emergentes casus humanos, hoc testamentum meum Juliano viro honesto, adjutore Johannis Forensis civit. Ravenn. scribendum dictavi, propria manu suscripturus; quod si jure civili vel protorio aut cujuslibet novella legis interventu forsitan valere nequiverit, $a b$ intestato vice codicillorum meorum valere volo. Quod cuique hoc testamento dedero, legavero, id, ut detur, prcestetur, fiat, fidei heredum meorum committo; quos liberos liberasve esse jussero, liberi liberceve sint tota. Te igitur sanctam ecclesiam catholicam Ravennatem heredem constituo

1 Ravennate ad omnia ssta consensi et susscribsi, et numero xli 
competente testes, ut suscriberent, conrogavi. Alba (lea) nione cum uxore et filiis suis ingenuos esse volo, civesque Romanos ${ }^{2}$. . . vir . . . ir . . . ${ }^{3}$

. . Johannis vir strenuus, huic testamentum rogatus a Mannane viro devoto, filio quondam Nanderit, ipso præsente et susscribente, atque ei testamentum relictum, per quo constituit heredem scam ecclesiam catholicam Ravennate, testis, suscribsi $\dagger$

Emilianus vir devotus Scriniarius gloriosa sedis, huic testamentum rogatus a Mannane v. d. testature, filio qd. Nanderit, ipso præsente et suscribente adque testamentum, per quod constituit heredem scam ecclesiam catholicam Ravennate testis suscribsi $\dagger$

Riccitanc v. c. huic testamento rogatus a Mannane v. d. testatore, filio qd. Nanderit, ipso præsente et suscribente, adque ei testamento relictum, per quo constituit hhdem scam ecclesiam catholicam Ravtem testis suscribsi

Theodosius v. d. Magistratus gloriosa sedis ${ }^{4}$ huic testamentum rogatus a Mannane $v$. d. testatore, filio qd. Nanderit, ipso præsente et suscribente atque ei testamentum relictum, per quo constituit heredem scam ecclesiam catholicam Ravennatem testis suscripsi $\dagger+\dagger$

Andreas vir honestus huic testamentum rogatus a Mannane v. d. testatore, filio qd. Nanderit, ipso præsente et suscribente adque ei relicto, per quo constituit heredem scam ecclesia Rav. testis suscribsi $\dagger+\dagger$

Quiriacus v. h. Orrearius ${ }^{5}$ uhic testamentu rogatus a Mannane v. d. testature, filio $q d$. Nanderit, ipso presente et suscribente, adque ei testamentu relictum, per quo costituit hiride $\overline{\text { sca }}$ eclisia Ravennatis, testis suscribsi.

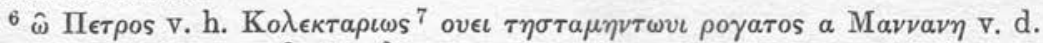

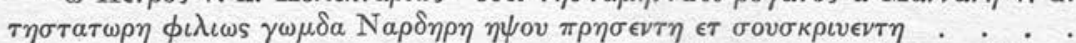

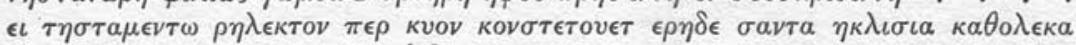
$\mathrm{P} a v \epsilon \nu \alpha \tau \eta \tau \eta \sigma \tau \eta \mathrm{s} \sigma o v \sigma \kappa \rho \iota \psi \eta \mathrm{\dagger}^{8}$

9 Julianus v. h. scribtor hujus testamenti, adjutor Johannis Forensis, habens stationem apud Sanctum Johannem Baptista, suscriptum complevi cos cos cos cos

Melminius ${ }^{10}$ Cassianus jun. Mag. Recitata apud me charta testamenti qd. Mannani devota memorice viri subnotavi, sub die Kal. Aprilium, Imp. Dn. Justino PP. Aug. anno decimo, P. C. ejus secundo anno septimo, Indictione octava Rav. $\dagger+\dagger$

11 Johannis v. h. For. hujus Civ. Rav. hunc testamentum Mannani v. d. per quo sibi hhdem constituit scam Eccl. Rav. scribtum a Juliano v. h. adj. meo, et a testibus roboratum et traditum complevi et absolvi.

12 Notitia testium:

Johannis vir st. fil. qd. Januari Præfectiani. ${ }^{13}$

Emilianus v. d. Scrin. g. s.

Riccitanc v. c. fil. qd. Montani.

Theodosius v. d. Mag. gl. s.

Andreas v. h. cata ipso Zenobio. ${ }^{14}$ 
Quiriacus v. h. Orr. qui tenet stationem ad domo Otratarit.

Petrus v. h. Collictar. fil. qd. Thomatis Defensoris.

${ }^{15}+$ Testamentum vitalem ${ }^{16}$ Mannanis v. d. factum sub die V. Kal. Martiarum Imp. Dn. Justino PP. Aug. anno decimo, P. C. ejus anno septimo, Indictione octava, Ravenne $\dagger$

17 . . 3 . post commendationem Johannis vir st. res . . . s est sub die Kal. Aprilium Imp. $\overline{D n}$. Justino PP. Aug. anno X., P.C. ejusdem secund. anno septimo, Ind. octava Rav.

1 Supplendum forte: Huic testamento ego Mannanes $v$. d. filius qd. Nanderit, in quo constitui heredem sanctam ecclesiam Ravennatem ad omnia suprascripta consensi et suscribsi etc.

${ }^{2}$ Conf. Novell. 78. cap. 1. Jure antiquo ingenuitatem liberto dedit Imperator, consentiente patrono, et quidem jus annuli, et natalium restitutionem. Dig. XL. 10. 11. Cod. VI. 8. Justinianus per c. 3. C. VI. 4. de bonis liberatorum, patronis concessit natalium restitutionem, absque Imperatoris interventu, libertis suis dare; per Novellam 78 etiam jus annuli, talibus libertis in genere dedit. Cf. Sabiniacum in: Gesch. des Röm. Rechts im Mittelalter. Tom. II. p. 128. Ceterum Koppius pro: et filiis legit: tribus.

3 Vestigia sunt subscriptionis manu propria testatoris factæ. Supplendum videtur: Mannanes vir devotus suscripsi.

${ }_{4}$ Militabant sub Magistro Officiorum.

5 De Horreariis vid. fr. 5. § 3. D. IX. 3. de his., qui effud. fr. 60 . § ult. D. XIX. 2. Locati. cf. Gothofred. Paratitl. ad Lib. VII. Cod. Theod.

6 Marinii lectio emendata est secundum ea, quæ monuit Koppius in: Heidelberger Jahrbücher der Literatur für Philologie. Jahrg. III. (1809) T. I. p. 29-36.

- Collectarii ad tributa excipienda et apud ecclesias constituti erant. Augustin. de Civit. Dei. L. XXII. cap. 8. nro. 18.

8 Apposita huic subscriptioni, in margine nota quædam manus propriæ. Conspicuntur enim literæ: $\chi \mu \eta$, quas explico: $\chi \epsilon i \rho \iota ~ \check{\epsilon} \mu \hat{\eta}$.

9 Interest spatium duarum unciarum.

10 Koppius legit: Malmonius.

11 Interest spatium pedis unius, et trium unciarum.

12 Interest spatium duarum unciarum.

13 Prafectianus i. q. Apparitor sive Officialis Præfecti prætorio.

14 кäd, prope Zenobium habitans.

15 Interest spatium quatuor unciarum.

16 Quid verbum vitalem sibi velit, incertum est. Marinius ait: "forse vitale, perchè quando fu scritta tal cosa, era in vita il Testatore tuttavia," sed ea displicent. Forte Mannanes alicui usumfructum sive reditus ad dies vitæ, seriore ævo vitales dictos, in iis bonis, quæ ecclesiæ Ravennati legaverit, reservavit; indeque factum, ut testamentum ipsum appellaretur testamentum vitale.

17 Supplendum videtur: Testamentum post (sive ad) commendationem Johannis viri strenui resignatum est sub die etc. 
xliv

TESTAMENTUM SOLLEMNE MANNANIS

In dorso literis minutissimis scriptum est :

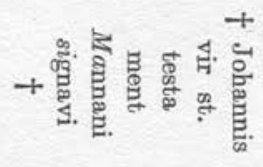

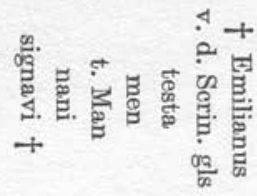

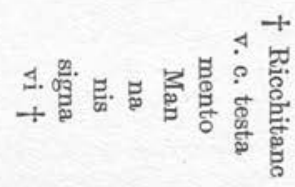

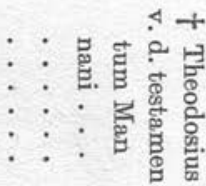

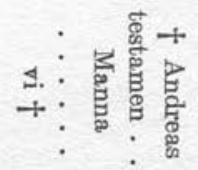

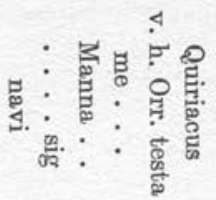

$\therefore: \therefore+$

. . .

$\therefore: \therefore \frac{7}{8}$

...

. : : 


\title{
(2) FRAGMENTUM INSTRUMENTI DONATIONIS A GAUDIOSO DEFENSORE FACT $A$
}

\author{
(SPANGenberg, No. XXX.)
}

I. Asservatur Bergomi (presso la Marchesa Antonia Solzi Suardi); scriptum in papyro. Publici juris factum: (1) a Canonico Maria Lupo in Codice diplomatico civitatis et ecclesiæ Bergomatis. (Bergomi 1784. fol.) pag. 402.-(2) a Marinio "I papiri diplomatici." nro. CX. pag. 169; junctis animadversionibus, pag. 325.326 .

II. Lacerum fragmentum continet donationis instrumentum, factum ecclesiæ Ravennati, a Defensore ejusdem ecclesiæ, Gaudioso, de horto, cum usu stabuli et putei. Supersunt nonnisi subscriptiones quatuor testium, et tabellionis, qui instrumentum scripsit. \#tatis incertæ est. Cum vero inter testes occurrat scholaris collegii Gentilium, conscriptum esse debet ante Justiniani tempora, si quidem vera sunt, quæ Gothofredus contendit, Justiniani scilicet ævo, nullos superfuisse milites gentiles, idque Justiniano ansam præbuisse, quominus titulum Codicis Theodosiani, de nuptiis gentilium suo Codici inserendum duxerit.

. . . tinus V. C. Domesticus Numeri felicium Letorum ${ }^{1}$ uhic usufructuariæ donationis chartule suprascripti hortus in integro, qui est in pergulis exornatus cum usu cortis ${ }^{3}$ et putei, adque ingresso et egresso, nec non et pariete a platea vel omnibus ad eumden pertinentibus, sicut superius legitur, facta a suprascripto Gaudioso reverentiss. Defensore sancte Ecclesiæ Rav. donatore in ssta sca Eccl. Ravenn., qui me presente suscripsit, et coram nobis ei relicta est, rogatus a ssto Gaudioso, testis suscripsi, et hanc chartulam posita super sancta Evvangelia ${ }^{3}$ Actionariis presente EIclesiæ a memorato Gaudiuso sub jusjurandum traditam vidi.

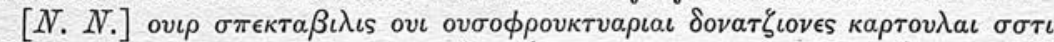

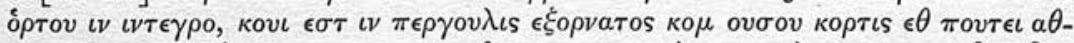

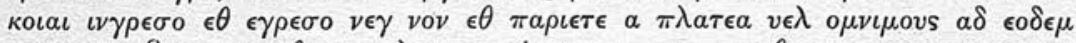

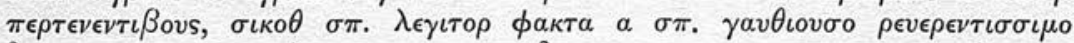

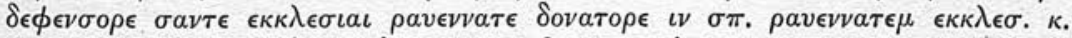

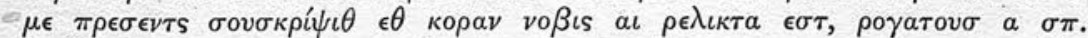

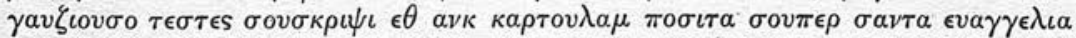

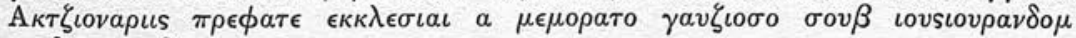

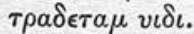

$[N . N$. $]$ Dom. Num. fel. Lecon. huic usufructuariæ donationis chartule ssti hortus in integro, qui est in pergolis exornatus, cum usu cortis et putei, adque ingresso et egresso, nec non et pariete a platea vel omnibus ad eumdem pertinentibus, sicut superius legitur, facta a ssto Gaudiosum reverentiss. Defensure sancte Eccl. Rav. donatore in ssta sancta Rav. Acclesia, qui me presente suscripsit, et coram nobis ei relicta est, rogatus a ssto Gaudiosum, testis suscribsi, et hanc chartulam positam super 


\section{xlvi}

sancta Evvangelia Actionariis præfatæ Ecclesie a memorato Gaudiosum sub jusjurandum traditam vidi.

[N. N.] vir discretus Scolaris collegii Gentilium huic usumfructuariæ donationis chartulce sste ortus in integro, qui est in pergolis exornatus, cum $u s u$ cortis et puteis, adque ingresso et egresso, nec non pariete a platea vel omnibus ad eandem pertinentibus, sicut superius legitur, facta a suprascripto Gaudioso reverentissimo Defensore sancte Æglesie Rav. donature in sstam scam Rav. Eglesie, qui me presente suscripsit, et quoram nobis ei relecta est, rogatus a ssto Gaudioso testis suscripsi, et in hanc chartulum posita super sancta Evvangelia Actionariis sancte Agglesie prefate a memorato Gaudioso sub jusjurandum traditam vidi.

.... s Primicerius Scola Forensium Civitatis Ravennatis seo Classis . . . hujus usufructuariæ donationis chartule $\overline{s s} t i$ hortis in integro, qui est in pergulis exhornatus, et omnibus ad eodem pertinentibus seo adjacentibus cum ingresso et egresso, sicut superius legitur, post roboratione testium atque tradetam complevi et absolvi.

Notitia testium, id est:

acius V. C. Dom. Num. fel. Let.

tinus V. C. Dom. Num, fel. Let.

1 Leti, populus barbarus, e quo numeri militum quidam eligebantur. Cf. Cangium v. Leti.

2 cors, cohors i. q. stabulum. Varro de re rustica. L. I. c. 13. L. III. cap. 3. Palladius de re rustica. L. I. c. 22.

3 Mos, qui seriore ævo in investituram per Sancta Evangelia, vel per Altare degenerasse videtur, de qua conferas Scriptores rei diplomaticæ. Juramentum super evangeliis primus introduxisse videtur Justinianus Novell. VIII. tit. 3.

\section{(3) INSTRUMENTUM DONATIONIS ECCLESIA RAVENNATI FACTAE A STEPHANO ILLUSTRI GRACO}

(Spangenderg, No. XXXVII.)

I. Asservatur Romæ in bibliotheca Vaticana, exaratum in papyro sex palmarum, quatuor unciarum longitudine, palmæ et dimidiæ latitudine. Mentionem ejus injecit Leo Allatius Animadv. ad Antiq. Etrusc. p. 83; primus vero illud edidit Marinius "I papiri diplomatici" nro. XCII. p. 142. 143. junct. animadv. p. 302-304. cf. et Tab. XIII.

II. Continet donationem Ecclesiæ Ravennati factam a Stephano, illustri Græco, habitante in Neapoli, et quidem Sæculo sexto, vel septimo. Initium instrumenti, Romæ conditi, deest. Donationis ipsius vestigia occurrunt in repertorii cujusdam Ravennatis Codice, Monachii asservato, et a Fantuzzio ${ }^{1}$ tum a $J . B$. Bernharto ${ }^{2}$ publici juris facto.

1 Monumenti Ravennati de' Secoli di mezzo per la maggior parte inediti. Venezia (1801. 4.) T. I. 50.

"Item in civitate Heugubio domum, quæ vocatur domnicalia $\overline{p o s}$ juxta S. Secundinum cum orto et vinea - - Item foris civit. fundum q. voc. Capell. villulas Labriano, vineola pos sstum fund. Villula, Fullonica, Ferrania, Pratalata, 
Casanovula habentem in ourte q. p. soaleniano et decano que obvener. sce. Rav.

Ecclie a qnd. Stephano magnifico viro q. mansit in civ. Neapuli."

2 Codex traditionum ecclesiæ Ravennatis; in: v. Aretin "Beyträge zur Gesch. und Literatur." T. VIII. p. 1-115. (Monachii 1807.)

† Ego Theudosius v. h. tabell. urb. Rom. habens stationem in porticum de Subora, Regione quarta, scriptor hujus chartulæ a die præsenti donationis, post testium subscriptiones et traditione facta, conplevi et absolvi.

Notitia testium id est

$\mathrm{Ba}(\mathrm{u})$ rracius V. C.

Maurinus v. h.
Johannis Domc. Num. Diac.

Chrisogonus v. c. cancell.

Dominicir(s) v. c. Optio Num.

Eq. Sermisiani.

\section{(4) INSTRUMENTUM DONATIONIS ECCLESIAE RAVENNATI FACT $A$ A SISIVERA, LIBERTA THEUDIFARA}

\section{(Spangenberg, No. XXXVIII.)}

I. Asservatur Romæ in bibliotheca Vaticana, exaratum in papyro, longitudine duodecim palmarum et dimidiæ. Publici juris factum: (1) a Maffeio "Istoria diplomatica." p. 143. sqq. e quo specimen scripturæ dederunt Monachi Benedictini in: Nouveau traité de diplom. T. IV. (2) a Marinio "I papiri diplomatici." nro. XCIII. p. 144-146; junct. not. p. 304-308.

II. Continet donationem, factam a Sisevera, liberta Theudifaræ nobilissimæ feminæ e Gothorum populo, et quidem ecclesiæ Ravennati, ejusque diacono Bo. Initium, sed pauculæ ejus lineæ tantum deesse videntur. Instrumentum Sæculo sexto, haud vero quinto, ut Maffeio placuit, adscribendum est.

† Bonus tabellio civitatis Rav. scribtor hujus chartulæ donationis portionis in integro fundi ssti Boloniani cum omnibus ad se generaliter pertinentibus, sicut superius legitur, post roboratam a testibus atque traditam complevi et absolvi. $\dagger$

$\uparrow$ Notitia testium, id est.

Armatus v. d. Schol. et Coll. a sca Eccl. ad signum. ${ }^{1}$

Adquisitus v. c. Optio Numeri Mediol.

Johannis v. h. Negotiator Syrus a Caput Porticus. ${ }^{2}$

Laurentius vir st. ex Ypod. Civ. Fanestr.

Julinus v. h. qui fuit Adj. qd. Marcatoris. ${ }^{3}$

Juvinus v. h. Horrearius. †

1 sive ad locum, scilicet ratione habita ad signum domus, ubi habitabat.

2 Regio in urbe Ravennate.

s scilicet tabellionis. Marcator tabellio occurrit infra in chartula damnatæ litis. 


\section{APPENDIX D}

\section{VERBATIM EXTRACT FROM ARS NOTARIATUS ${ }^{1}$}

The requisit Solemnities in all Instruments, by the Civil Law, were these following: The Year of the Emperor's Reign; the Name of the present Consul; the Number of the Indiction; the Month, and Day of the Month on which the Instrument was made, Novel 47. cap. 1. in pr. $\S 1$. the Witnesses Names and Designations present, Novel 73, cap. 1. and 2. and see Wesenb. ad Pand. de fide instr. $n$. 5 . the Name of the Notary: and to all which the Emperor Maximilian, in his Constitution concerning Notaries, made in the Year $1512, \S 1$. ordered, that the Name of God should be invocated in the Beginning of all Instruments.

In this Kingdom Instruments of Moment are compleated by the Solemnities following: 1. The Invocation. 2. The Year of our Lord. 3. The Month. 4. The particular Day of the Month. 5. The Year of our Sovereign's Reign. 6. The Presence of the Notary and Witnesses. 7. The Compearance of the Party, or his Procurator. 8. The substantial Part of the Instrument. 9. The requiring Instruments from the Notary by the Parties concerned upon what was done. 10. The Place where, and the particular Hour of the Day in which the Instrument was taken. 11. The Names and Designations of the Witnesses present. Lastly, The Notary's Docquet. All which will be clearer by the following Example.

$I^{N}$ nomine Domini ${ }^{2}$ nostri Jesu Christi, Amen. Per hoc prcesens anno incarnationis Domini millesimo septingentesimo trigesimo nono, mensis vera Decembris die vigesima prima, regnique $S . D . N .^{3}$ Georgii Secundi, Dei gratia, Magnce Britannia, Francia \& Hibernice, fideique defensoris, anno decimo tertio, in mei Notarii publici testiumque subscribentium ${ }^{4}$ prcesentia personaliter comparuit $A$, [hoc loco instrumenti pars substantialis inseritur, \& deinde subsequuntur hæc verba] de \& super quibus omnibus \& singulus dictus $A$, a me Notario publico subscribente, sibi fieri petiit unum vel plura instrumentum seu instrumenta, publicum seu publica. Acta erant hoc Edinburgi, in domo B mercatoris ibidem, in clausura vulgo vocata — \& in inferiora camera ejusdem, horas inter — \& - ante [vel post] meridiem, die, mense, anno Domini regnique Regis suprascriptis, prcesentibus ibidem probis viris $C \& D$ testibus ad promissa vocatis pariterque rogatis \& requisitis. [Deinde subsequitur signum cum sigillo Notarii.]

1 Part II. Tit. I. p. 46 et seq. (Edin. 1740).

2 Vel, In Dei nomine, Amen. Vel, In nomine Patris, Filii \& Spiritus Sancti, Amen.

${ }^{3}$ By these Letters S. D. N. is to be understood serenissimi Domini nostri: And I find that the Roman Emperors, in all publick Instruments, were called Sacratissimi.

- In old Stile it was subscriptorum, but since the Act of Parliament 1681, all Witnesses must sign Instruments of Importance, (as shall be noticed hereafter); and therefore, since that Act, this Word is changed from subscriptorum to subscribentium. xlviii 


\section{The same in English.}

T $\mathrm{N}$ the Name of God, Amen. Be it known to all Men by this present 1 publick Instrument, that upon the Twenty first Day of December One thousand seven hundred and thirty nine Years, and of the Reign of our Sovereign Lord George the Second, by the Grace of God, King of Great Britain, France, and Ireland, Defender of the Faith, the thirteenth Year, in presence of me Notary-Publick, and Witnesses subscribing, compeared personally $A$, [here insert the substantial part of the Instrument, and then the formal, as follows;] whereupon all and sundry the Premisses the said $A$ asked, required and took Instruments, one or moe, from me Notary-Publick. These Things were done at Edinburgh, in the House of $B$ Merchant there, in - Close, and in the lower Room thereof, betwixt the Hours of - - and - before [or after] Noon, before, and in Presence of $C$ and $D$, Witnesses to the haill Premisses specially called and required, \&c. 


\section{APPENDIX E}

The Latin used in Appendix A of the text of Novels XLIV. and LXXIII. is that of Gothofred's version. That version is certainly marred by a superfluity of punctuation and, accordingly, translation into English has not been easy. Gothofred's version has been used in order to obtain the benefit of his numerous valuable notes which obviously could not be related to any other version. Where exceptional points of difficulty have arisen recourse has been made to Schöell's translation (Berlin, 1914) and some of the more important passages are reproduced hereafter, referenced to Gothofred's version (supra) by side-references I., II., etc.

\section{I. (Appendix A, p. ii). Schöell:}

"Cum mulier diceret non hæc esse ab ipsa mandata quæ charta diceret, is qui litem audiebat, a tabellione discere rei veritatem cupiebat itaque tabellionem adduxit."

\section{II. (Appendix A, p. iii). Schöell:}

"Manifesto periculum esset ne undique negotii notitia intercideret." In effect, the absence of witnesses as confirmatory proof literally "euts off" a complete and satisfactory record of the transaction.

\section{III. (Appendix A, p. iv). Schöell:}

"Ut propter hunc metum circa instrumenta et justi et cautiores fiant, nec propter suam socordiam et luxuriam alienas fortunas evertant." "Evertant" certainly gives a better sense than "corrumpant." Note also the addition of "propter hunc metum" as reinforcing the reason for punishment.

\section{IV. (Appendix A, p. v):}

Dominus stationis has received various interpretations according as statio has been used in differing circumstances. According to the Vocabularium Jurisp. Rom. Tom. V. (Berlin, 1931), there are four main readings of statio.
I. Taberna. Ulp.
II. Locus ubicumque naves tuto stare possunt.
III. Statio militaris. Mod. (qui stationis munus relinquit).
IV. Statio iumentorum. Ulp. (si domum ad stationem iumentorum locaverit).

Invoking the aid of Cujacius (Appendix A, p. xi.), statio in the passage under consideration may mean the actual office or "chambers" where the tabellio conducted his business, and the dominus stationis accordingly simply the landlord whose tenant is the tabellio. According to Spangenberg (Appendix C, p. xlvii, supra) "Ego Theudosius v. h. tabell. urb. Rom. habens stationem in porticum de Subora, Regione quarta . . .," which undoubtedly gives support to that interpretation. Obviously Scott's translation of dominus stationis as "Chief of the Body of Notaries" cannot possibly fit the passage under review. There is also some ground for the view that statio may mean "office" in the sense of e.g. a church "living" where there is location as well as revenues, rights and privileges. The statio, or notarial office (stand or etude) as a lucrative position, might be granted to a layman who farmed it out to a notary. It is probable that in each district there was a limited number of stationes so that the owner of a statio had a monopoly in his area. Cujacius at the place above 
noted might equally be held to support that sense. Schöell's translation of the passage is here reproduced for comparison: "Quodsi is, cui post præsentem legem contra ea quæ a nobis constituta sunt instrumentum conficiendum mandatur, forte non sit dignus qui potestatem stationis suscipiat, tabellio quidem modis omnibus eo iure privetur, alter autem in eius locum promoveatur, ita tamen ut nullum omnino damnum inde patiatur stationis dominus, si quis sit ex extraneis nee vero tabellio ipse, neve reditus qui inde redundant amittat: sed ille solus qui talia commentus et officium suum explere dedignatus est, primatu exuatur, reliqua vero omnia iura stationis integra dominis eius serventur praeter tabelliones qui talia deliquerunt." It will be seen that the Latin phrase dominus stationis has simply been retained in the English Calendar.

\section{V. (Appendix A, p. vii). Schöell:}

"Quodsi quid adversus hæc fiat atque alteri mandatum sit, tum tabellio qui auctoritatem habet pœnæ a nobis supra definitæ subiciatur, ipsa tamen instrumenta propter utilitatem contrahentium irrita ne fiant."

This translation certainly helps to clarify the meaning.

VII. (Appendix A, p. xiv). Schöell:

"Deposito quoque litteris celebrato." Giving the meaning stated in the English Calendar-"deposits constituted in written instruments"- which is obviously more accurate than "instruments of deposit," the natural translation of Gothofred's Latin text.

\section{VIII. (Appendix A, p. xv). Schöell:}

"Quoniam qui scripsisse dicebatur non confessus est suas esse litteras."

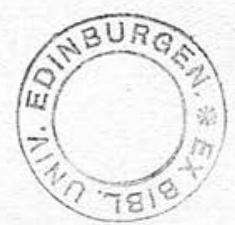

